UNIVERSIDADE FEDERAL DE MINAS GERAIS

ESCOLA DE CIENCIA DA INFORMAÇÃO

Gláucia Aparecida Vaz

A IMPORTÂNCIA DOS ESTUDOS DE USUÁRIOS NA FORMAÇÃO DO ARQUIVISTA

Belo Horizonte

2015 
Gláucia Aparecida Vaz

\section{A IMPORTÂNCIA DOS ESTUDOS DE USUÁRIOS NA FORMAÇÃO}

\section{DO ARQUIVISTA}

Dissertação apresentada ao Programa de PósGraduação em Ciência da Informação da Escola de Ciência da Informação da Universidade Federal de Minas Gerais para obtenção do grau de Mestre em Ciência da Informação.

Linha de Pesquisa: Informação, Cultua e Sociedade

Orientador: Professor Doutor Carlos Alberto Ávila Araújo

Belo Horizonte

2015 


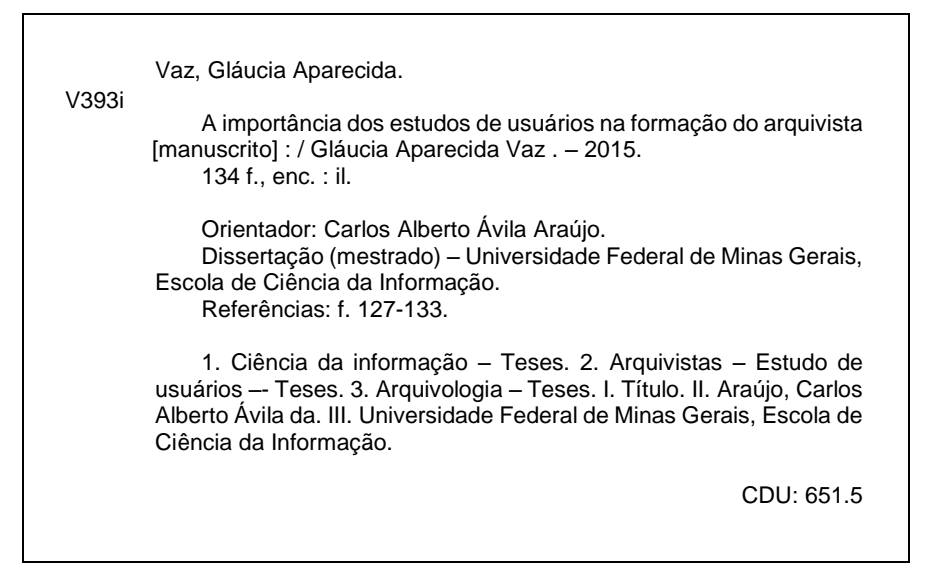

Ficha catalográfica: Biblioteca Prof Etelvina Lima, Escola de Ciência da Informação da UFMG. 


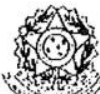 \\ UFMG \\ Universidade Federal de Minas Gerais \\ Escola de Ciência da Informação \\ Programa de Pós-Graduação em Ciência da Informação}

FOLHA DE APROVAÇÃO

"A IMPORTÂNCIA DOS ESTUDOS DE USUÁRIOS NA FORMAÇÃO DO ARQUIVISTA"

Gláucia Aparecida Vaz

Dissertação submetida à Banca Examinadora, designada pelo Colegiado do Programa de Pós-Graduação em Ciência da Informação da Universidade Federal de Minas Gerais, como parte dos requisitos à obtenção do título de "Mestre em Ciência da Informação", linha de pesquisa "Informação, Cultura e Sociedade".

Dissertação aprovada em: 19 de agosto de 2015

Por:

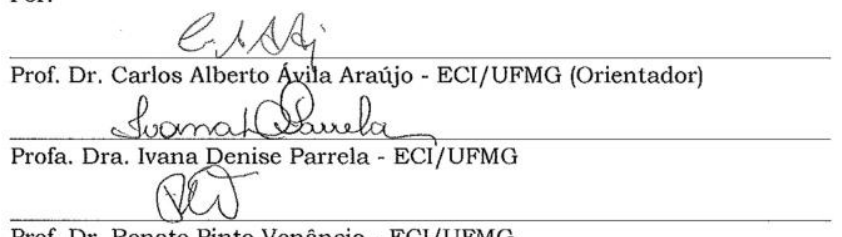

Prof. Dr. Renato Pinto Venâncio - ECI/UFMG

Aprovada pelo Colegiado do PPGCI

Berendón

Profa. Beatriz Valadares Cendón Coordenadora
Versão final Aprovada por

$$
\text { CAAf: }
$$

Prof. Carlos Alberto Ávila Araújo Orientador 


\section{(5) \\ UFMG \\ Universidade Federal de Minas Gerais \\ Escola de Ciência da Informação \\ Programa de Pós-Graduação em Clência da Informação}

ATA DA DEFESA DE DISSERTAÇ̃̃O DE GLÁUCIA APARECIDA VAZ, matrícula: 2013708810

As 9:00 horas do dia 19 de agosto de 2015, reuniu-se na Escola de Ciência da Informação da UFMG a Comissão Examinadora aprovada ad referendum pelo Sub-coordenador do Programa de Pós-Graduaçāo em Ciência da Informaçāo em 16/07/2015, para julgar, em exame final, o trabalho intitulado A importância dos estudos de usuários na formação do arquivista, requisito final para obtenção do Grau de MESTRE em CIÊNCIA DA INFORMAÇÃo, área de concentração: Produção, Organização e Utilização da Informação, Linha de Pesquisa: Informação, Cultura e Sociedade. Abrindo a sessão, o Presidente da Comissão, Prof. Dr. Carlos Alberto Ávila Araújo, após dar conhecimento aos presentes do teor das Normas Regulamentares do Trabalho Final, passou a palavra à candidata para apresentação de seu trabalho. Seguiu-se a argüição pelos examinadores com a respectiva defesa da candidata. Logo após, a Comissão se reuniu sem a presença da candidata e do público, para julgamento e expedição do resultado final. Foram atribuídas as seguintes indicações:

Prof. Dr. Carlos Alberto Ávila Araújo - Orientador $\quad$ APROVADA

Profa. Dra. Ivana Denise Parrela $\quad$ APROVADA

Prof. Dr. Renato Pinto Venâncio $\quad$ APROVADA

Pelas indicações, a candidata foi considerada APROVADA. A banca ressalta a necessidade de correções obrigatórias para a versão definitiva da dissertação.

$\mathrm{O}$ resultado final foi comunicado publicamente à candidata pelo Presidente da Comissão. Nada mais havendo a tratar, o Presidente encerrou a sessão, da qual foi lavrada a presente ATA que será assinada por todos os membros participantes da Comissão Examinadora.

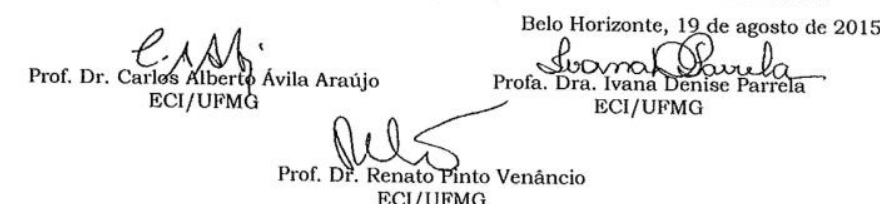
ECI/UFMG

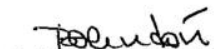




\section{AGRADECIMENTO}

A Deus, pela força concedida em momentos difíceis.

Aos meus pais, pelo companheirismo, pela batalha, pelo apoio, pela compreensão das minhas ausências...

Obrigada Adilson por ter abraçado os meu sonhos, por ter me permitido sonhar.

Ao meu orientador Carlos Alberto Ávila Araújo, por todo conhecimento compartilhado, pela paciência, pela oportunidade de crescimento, pelo exemplo.

Ao meu professor e eterno amigo René Lommez Gomes, por não deixar eu desistir do meu sonho, pelo apoio no momento fundamental.

Aos meus colegas de curso, pela injeção de ânimo durante a minha trajetória. 


\section{RESUMO}

Neste estudo busca-se demonstrar, de acordo com as atribuições dos arquivistas, sua formação profissional e práticas profissionais, de que forma as abordagens dos "Estudos de Usuários" podem contribuir para melhoria dessas práticas. Discute-se sobre o arquivista, e as funções atribuídas ao profissional, e de que forma seu papel foi se transformando dentro da sociedade. A partir daí aborda-se os seus diversos campos de atuação profissional, que se concentra hoje, em grande parte, na administração pública. Busca-se compreender as questões relacionadas ao acesso aos arquivos, a partir do conhecimento da legislação mundial e brasileira a respeito do direito ao acesso à informação. A partir das leis é possível identificar de que forma o acesso é realizado na prática no Brasil. É apresentado também um histórico sobre os estudos de usuários na arquivologia com a questão da abertura dos arquivos até a consolidação de uma lei de acesso, relacionando esta evolução desde os seus primeiros estudos na década de 1960 até o estado do pensamento atual na área. Para avaliar a importância da presença de disciplinas voltadas para estudos de usuários nos currículos dos cursos, foi feita uma avaliação da situação das disciplinas por meio de suas ementas oferecidas em cada curso. Foram realizadas entrevistas com professores e coordenadores de oito cursos de arquivologia do país, a fim de entender questões históricas relacionada ao acesso aos arquivos, impactos das novas tecnologias e da Lei de Acesso à Informação, o uso e usuários de arquivos em suas três fases, estado da arte da discussão dos estudos de usuários nos arquivos e práticas capazes de garantir o acesso e promover o reconhecimento d arquivo como espaço de construção da memória coletiva e promotor de cidadania. Ao final do trabalho, é possível perceber que o cenário atual é favorável para consolidar ações e práticas, mas também de abrir uma agenda de investigação voltada para as especificidades dos usuários de arquivos.

Palavras-chave: Formação do arquivista. Arquivologia. Estudos de usuários. Mediação da informação. 


\begin{abstract}
This study aims to demonstrate, according the archivists attributions, their professional background and practices, how the "Users Studies" approach can contribute to improve those practices. It discusses about the archivists, their professional roles and how they have been changed in the society context. Thenceforth it addresses the many fields of professional performances, more concentrated currently in the public administration. It seeks to understand questions related to the files access, using the world and Brazilian laws, about the information access rights. Understanding these laws it makes possible to recognize how that access is made in Brazil. It's shown a historical background about the users studies inside archiving area, from the files opening process to a consolidated law access, relating that evolution from the first studies in the 60s to the current thoughts in the area. To evaluate how important are the users studies classes a questionnaire was developed to evaluate them inside each course program. Interviews were made with teachers and coordinators from eight archiving undergraduate courses in the country, to understand some historical questions about file access, new technologies impact and the "Information Access Law", the use and files users on three phases, state of the art of the discussion about users studies in archiving area, and practices to guarantee access and promote file recognition as a construction space of collective memory and citizenship promoting. At the end it is possible to realize that the current scenario is friendly to consolidate actions and practices, but also to open an investigation agenda turned to the files users specifications.
\end{abstract}

Keywords: Archivist formation. Archivology. Users studies. Mediation of information. 


\section{LISTA DE QUADROS}

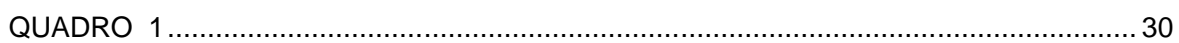

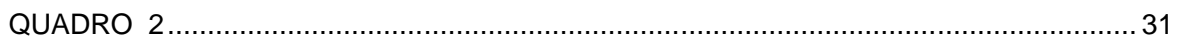

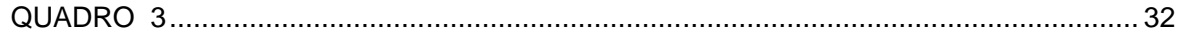

QUADRO 4

QUADRO 5

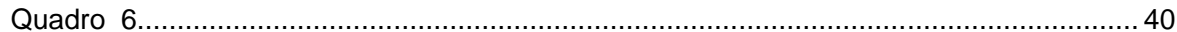

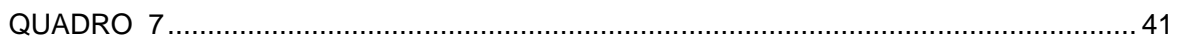

QUADRO 8

QUADRO 9

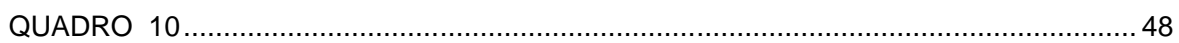

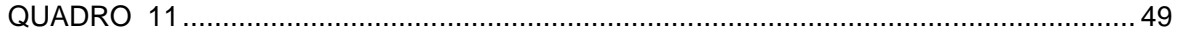

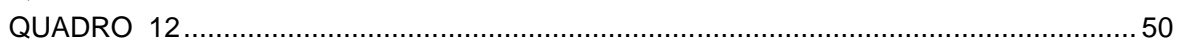

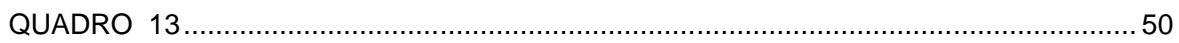

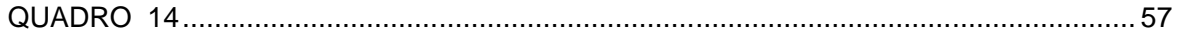

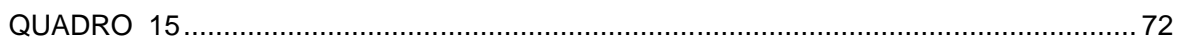

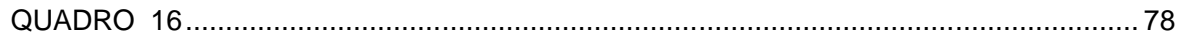




\section{LISTA DE ABREVIATURAS E SIGLAS}

$A A B$

$\mathrm{AAQ}$

ALA

APDIS

BAD

CBA

CFE

CIA

CNA

CNE

CPA

Ebsi

$\mathrm{ECl}$

FURG

IBGE

IIA

INCl-

TE

LDB

MAN

MEC

NA

ONG

Reparq

SAA

SESU

TCC

TIC

UEL

UEPB
Associação dos Arquivistas Brasileiros

Associação de Arquivistas Quebequenses

American Library Association

Associação Portuguesa de Bibliotecários,

Associação Portuguesa de Bibliotecários, Arquivistas e Documentalistas

\section{Congresso Brasileiro de Arquivologia}

Conselho Federal de Educação

Conselho Internacional de Arquivos

Congresso Nacional de Arquivologia

Conselho Nacional de Educação

Curso Permanente de Arquivos

École de Bibliothéconomie et dês Sciences de l'Information

Escola de Ciência da Informação

Universidade Federal do Rio Grande

Instituto Brasileiro de Geografia e Estatística

Information Industry Association

Associação Portuguesa para o Desenvolvimento da Informação Científica e Técnica

Lei de Diretrizes e Bases

Mensário do Arquivo Nacional

Ministério da Educação e Cultura

Arquivo Nacional

Organização Não Governamental

Reunião Brasileira de Ensino e Pesquisa em Arquivologia

Sociedade dos Arquivistas Americanos

Secretaria de Educação Superior

Trabalho de Conclusão de Curso

Tecnologias da Informação e da Comunicação

Universidade Estadual de Londrina

Universidade Estadual da Paraiba 


$\begin{array}{ll}\text { Ufam } & \text { Universidade Federal do Amazonas } \\ \text { UFBA } & \text { Universidade Federal da Bahia } \\ \text { Ufes } & \text { Universidade Federal do Espírito Santo } \\ \text { UFF } & \text { Universidade Federal Fluminense } \\ \text { UFMG } & \text { Universidade Federal de Minas Gerais } \\ \text { UFPB } & \text { Universidade Federal da Paraiba } \\ \text { UFRGS } & \text { Universidade Federal do Rio Grande do Sul } \\ \text { UFSC } & \text { Universidade Federal de Santa Catarina } \\ \text { UFSM } & \text { Universidade Federal de Santa Maria } \\ \text { UnB } & \text { Universidade de Brasília } \\ \text { Unesco } & \text { Organização das Nações Unidas para a Educação, a } \\ & \text { Ciência e a Cultura } \\ \text { Unesp } & \text { Universidade Estadual Paulista } \\ \text { Unirio } & \text { Universidade Federal do Estado do Rio de Janeiro } \\ \text { USP } & \text { Universidade de São Paulo }\end{array}$




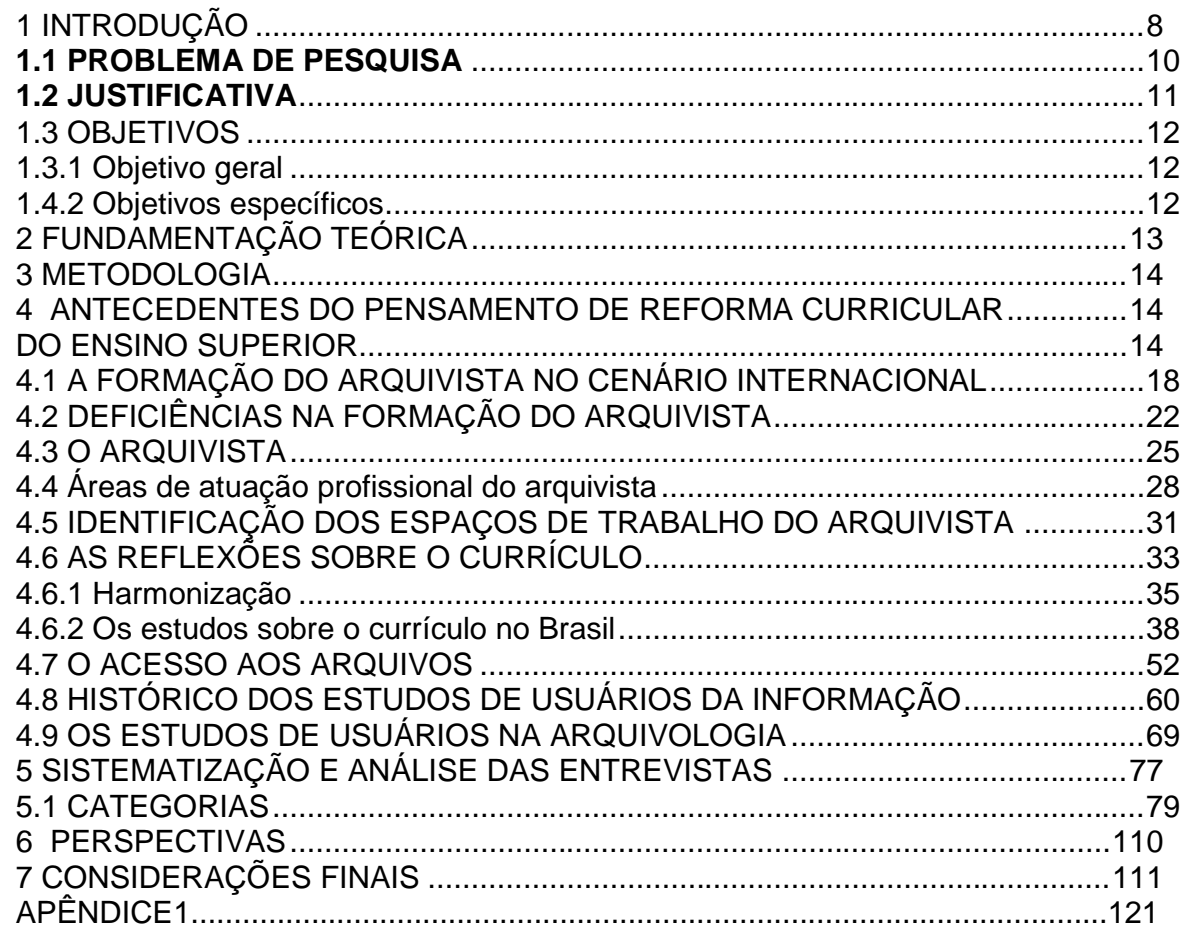




\section{INTRODUÇÃO}

O presente trabalho busca avaliar as disciplinas voltadas para os "Estudos de usuários", oferecidos atualmente nos 16 cursos de arquivologia no país. A ideia desse projeto iniciou-se ainda durante a graduação, quando tive a oportunidade de trabalhar em um projeto do "Programa Especial da Graduação", orientado pelo Professor Doutor Carlos Alberto Ávila Araújo. Este projeto estava vinculado ao colegiado do curso de arquivologia da Escola de Ciência da Informação da Universidade Federal de Minas Gerais, intitulado "Bases de dados digital da produção científica brasileira e suas relações com a ciência da informação". O projeto tinha como objetivo mapear a produção científica brasileira em arquivologia e criar uma base de dados onde os artigos encontrados pudessem ser reunidos e disponibilizados em um só lugar.

A partir do envolvimento nesta pesquisa, tive a oportunidade de conhecer de uma maneira mais próxima e profunda os atuais dilemas vividos pela arquivologia, como sua busca por consolidação do campo e auto-reconhecimento como ciência. No mesmo período do desenvolvimento desse projeto, em 2010, foi realizada a I Reunião Brasileira de Ensino e Pesquisa em Arquivologia (REPARQ), que foi um evento que procurava dar continuidade às reflexões sobre a formação do arquivista, iniciadas em 1995 por José Maria Jardim na Reunião Brasileira de Ensino em Arquivologia. Estes acontecimentos me levaram a refletir sobre o profissional arquivista, qual é o seu papel na sociedade, como o arquivo poderia ser instrumento de promoção de cidadania.

Com a Lei de Diretrizes e bases de Educação, de 1996, o currículo mínimo é banido, dando flexibilidade ao currículo e liberdade às universidades para criar matrizes curriculares que atendam as diversas necessidades do mercado de trabalho e da sociedade de maneira geral. As REPARQ's surgem então em 2010 procurando discutir os fatores da formação profissional e da pesquisa dentro da arquivologia. O que se propôs na primeira Reunião foi um movimento para uma harmonização dos currículos de arquivologia, diferente da harmonização proposta pela Unesco em 1974. A arquivologia vive um momento então que procura um autoconhecimento, discutindo os pontos fortes e quais ainda é preciso avançar.

Inicialmente pensei em realizar um estudo analisando todos os currículos dos 16 cursos de arquivologia, com o objetivo de classificar e mapear as disciplinas específicas da arquivologia e as áreas interdisciplinares, de modo a identificar quais áreas contribuem de forma mais significativa na formação do arquivista. O projeto foi alterado quando ao desenvolver um trabalho final de uma disciplina na pós-graduação, percebi que havia uma lacuna na disciplina "Estudos de usuários" nos cursos de arquivologia. Em alguns momentos esta disciplina é ofertada como obrigatória, em outros como optativa e em alguns outros casos chega a ser classificada como disciplina específica da arquivologia. Além disso, notou-se em 
alguns casos, um conteúdo que não atende os diversos tipos de usuários de arquivos, e uma dificuldade na nomenclatura desse tipo de estudo. Todas essas reflexões levaram então a desenvolver um estudo que pudesse analisar essa disciplina nos currículos dos cursos. Essa análise busca compreender a estrutura dessa disciplina e de que forma ela pode contribuir para o acesso aos arquivos.

O trabalho inicia-se passando por uma discussão buscando entender os acontecimentos que levaram à necessidade de alterações dos currículos de formação superior. Procura demonstrar os cenários diversos e complexos do mundo do trabalho, os avanços tecnológicos, as novas formas de operar o capitalismo que culminaram na demanda de uma reforma na formação dos profissionais especializados, dando ênfase no reflexo dessas demandas sobre a formação do arquivista.

É abordado também o cenário internacional da formação do arquivista e suas "tradições" ou modelos de ensino, no âmbito internacional, que podem ser classificadas em cinco categorias: a tradição européia, a tradição ítalo-hispânica, a tradição britânica, a tradição norte-americana e aquelas dos países em desenvolvimento, em que, apesar de uma homogeneidade, possuem também algumas características específicas.

Após a apresentação de seus modelos passa-se pela formação do arquivista no cenário nacional desde a criação do primeiro curso no Centro Permanente de Arquivos (CPA) do Arquivo Nacional, passando pela regulamentação da profissão, até a ampliação do número de cursos oferecidos no país.

Discute-se sobre o arquivista, e as funções atribuídas ao profissional, e de que forma seu papel foi se transformando dentro da sociedade. A partir daí aborda-se os seus diversos campos de atuação profissional, que se concentra hoje, em grande parte, na administração pública.

As reflexões sobre o currículo também é parte importante deste trabalho, mostra a evolução dos estudos sobre o currículo de arquivologia e formação do arquivista, desde o primeiro estudo apresentado por Jardim em 1995, até os últimos estudos apresentados nos REPARQ's. Neste capítulo é possível acompanhar a transformação sofrida pelos currículos, saindo de um modelo rígido do currículo mínimo, para matrizes curriculares bastante flexíveis.

Busca-se compreender as questões relacionadas ao acesso aos arquivos, a partir do conhecimento da legislação mundial e brasileira a respeito do direito ao acesso à informação. A partir das leis é possível identificar de que forma o acesso é realizado na prática no Brasil.

A medida que este projeto busca analisar as disciplinas sobre estudos de usuários nos curso de arquivologia, é traçado um histórico desde o surgimento dos primeiros estudos de usuários, com dados mais quantitativos até o modelo atual centrado no usuário, que tem como objetivo entender o comportamento de busca de informação desse usuário para oferecer sistemas que se adaptem às suas necessidades. É apresentado o histórico destes estudos 
na arquivologia, e as diversas ações que podem ser desenvolvidas para atender aos mais variados tipos de usuários de arquivos.

É apresentado uma avaliação da situação atual das disciplinas nos cursos. Foram realizadas entrevistas com professores e coordenadores de oito cursos de arquivologia do país, a fim de compreender questões históricas relacionada ao acesso aos arquivos, impactos das novas tecnologias e da Lei de Acesso à Informação, o uso e usuários de arquivos em suas três fases, estado da arte da discussão dos estudos de usuários nos arquivos e práticas capazes de garantir o acesso e promover o reconhecimento do arquivo como espaço de construção da memória coletiva e promotor de cidadania. Ao final é possível compreender de que forma os estudos de usuários podem contribuir para a prática do acesso e para ajudar ao arquivista cumprir seu papel não só de gestor da informação, mas também, de promotor de cidadania.

\subsection{PROBLEMA DE PESQUISA}

Diante do quadro atual vivenciado pela Arquivologia, em que os professores e pesquisadores na área buscam um entendimento da composição da Arquivologia enquanto ciência. A avaliação e restruturação do seu currículo nas universidades brasileiras tem sido uma temática recorrente. Desde a década de 30 , quando o mundo passou por intensas transformações econômicas e políticas que mudaram o ambiente arquivístico. A partir da década de 40 a discussão se tornou mais intensa em relação a contribuição de outras disciplinas para a formação do profissional arquivista. Em 1993, um grupo de estudos formado por Ham, Boles, Hunter e O'Toole, questionaram sobre o papel dos conhecimentos históricos na formação arquivística. Em 1974, a Unesco inicia um movimento para a harmonização das formações de Arquivologia, Biblioteconomia e Documentação. Mas em 1992, no XIIํCongresso Internacional de Arquivos em Montreal, constatou-se uma diminuição na tendência de harmonização dos três cursos e começam a caminhar "[...] na direção de uma pesquisa sobre a identidade profissional específica do arquivista" (COUTURE; MARTINEAU; DUCHARME, 1999, p. 86).

Neste período de transição, as discussões sobre a composição curricular dos cursos de Arquivologia no Brasil, tem se tornado cada vez mais frequentes. Diversos trabalhos vêm sendo desenvolvidos no Brasil, desde 1995, com a I Reunião Brasileira de Ensino em Arquivologia, que inaugura a produção de pesquisa voltadas para a formação do arquivista no país. Os trabalhos apresentados até o momento buscam mapear as contribuições de área correlatas à arquivologia na sua estruturação curricular. Este estudo pretende, portanto, voltar-se para análise de uma disciplina, para demonstrar sua estrutura atual e de que forma ela pode ajudar na efetivação de políticas de acesso. De acordo com Jardim (1999) existem 
poucos estudos sobre estudos de usuários em arquivos, a ausência de manuais que tratem da temática também é destacado pelo autor, que chama atenção para a necessidade de abertura de uma agenda de investigação mais profunda sobre o assunto. O que pretende-se é desenvolver material que possa ser utilizado para um aprofundamento da temática na área.

\title{
1.2 JUSTIFICATIVA
}

O papel que o profissional de arquivo exercia na sociedade tomou um novo formato, para além do tratamento dos arquivos, inicialmente os permanentes em seguida os arquivos correntes e intermediários. Sua função atinge uma nova dimensão e o arquivista passa a interagir com toda a estrutura organizacional das instituições, atuando como gestor da informação arquivística, com o objetivo primordial de atender à administração, mas também de zelar e proteger a memória e a cultura nacionais, além de produzir conhecimento através de pesquisas científicas (MARIZ, 2012, p. 12).

Cada vez mais a arquivologia tem se destacado no campo da informação, com sua preocupação com a guarda e organização dos documentos em seus diferentes suportes, para uma recuperação rápida e eficaz dos dados, visando atender a demanda da sociedade atual. $\mathrm{O}$ arquivo é uma unidade de informação conectada com a sociedade ao qual pertence e compõe cada vez mais um sistema complexo e interconectado.

Por ser uma unidade de informação conectada e integrada à comunidade que o cerca, é extremamente necessário ao campo compreender, ou até mesmo "criar" metodologias que possam atender cada usuário, dentro das especificidades de cada um. A abertura dos arquivos, a criação de uma Lei de Acesso, faz com que o arquivo abra suas portas e janelas para um novo horizonte. No Congresso Internacional de Arquivos de 1996, assinalava Ketellar:

\begin{abstract}
Aqui estamos nós, 2500 arquivistas juntos, conversando um semana inteira sobre a nossa profissão. Mas onde estão os usuários, nossa razão de ser? Eles estão do lado de fora, num mundo que nós não podemos ver porque não há janelas, não há janelas neste salão, não há janelas nos depósitos arquivísticos, não há janelas em nosso pensamento profissional. (KETELLAR, 1996, p. tal).
\end{abstract}

Nota-se então que há muito tempo os profissionais de arquivos e pesquisadores da área vem chamando para a necessidade de se reconhecer o usuário como fator primordial em todo o processo da gestão documental. Há uma emergência em realizar estudos voltados para as especificidades dos arquivos, que diferença-se de outras unidades de informação. Os avanços tecnológicos fazem que o arquivo saia do "seu lugar" (JARDIM ,1999), cria novos tipos de usuários, o desenvolvimento de novas práticas profissionais, transformando o arquivo em uma unidade dinâmica. 
$\mathrm{O}$ arquivista hoje exerce a função de mediador, promovendo a relação entre sujeito (cidadão) e objeto (informação) (BATISTA, 2014). A mediação cultural consiste em construir um ambiente agradável e "familiar para o sujeito, para que ele possa absorver ao máximo as potencialidades de seu objeto, procurando dessa forma sanar as necessidades de informação dos usuários. E indo um pouco mais além, entender as necessidades que não são explicitadas pelo usuário.

Considera-se neste trabalho que as metodologias dos estudos de usuários podem ajudar de forma positiva na construção de todo esse processo.

\subsection{OBJETIVOS}

Dentro dessa concepção, a pesquisa proposta buscará atingir os seguintes objetivos geral e específicos:

\subsubsection{Objetivo geral}

Analisar como se estruturam as disciplinas sobre "Estudos de Usuários" nos 16 cursos de Arquivologia do Brasil e analisar deque forma podem colaborar para ampliar o acesso aos arquivos.

\subsubsection{Objetivos específicos}

- Avaliar se a atual estrutura das disciplinas sobre "Estudos de Usuários" atendem às necessidades específicas da Arquivologia;

- $\quad$ Conhecer a visão dos professores que ministram a disciplina sobre a mesma;

- $\quad$ Demonstrar de que forma os "Estudos de Usuários" podem contribuir para a promoção do acesso;

- Avaliar os impactos da Lei de Acesso à Informação nas práticas arquivísticas;

- $\quad$ Apresentar novas propostas de mediação e difusão da informação em arquivos;

- $\quad$ Compreender as diferenças no uso e usuários de arquivos. 


\section{FUNDAMENTAÇÃO TEÓRICA}

Ao estudarmos a trajetória dos cursos arquivologia no Brasil, verificamos preocupações e iniciativas voltadas para a formação de profissionais desde o final do século XIX, intensificando-se sobretudo a partir dos anos 1950 e culminando no primeiro curso de arquivologia, o Curso Permanente de Arquivos (CPA), de 1960. Em todo o mundo a partir da década de 40 a ideia de arquivista-historiador, de uma arquivologia dominada por disciplinas da história começa a se esvair. A formação do arquivista muda de situação, deixando os departamentos de história para se inscrever nas escolas de biblioteconomia e ciência da informação (LAUJENESSE, 1986).

No Brasil, José Maria Jardim e Maria Odila Fonseca inauguram os estudos voltados para os currículos e a formação dos arquivistas com a publicação do livro "A formação do arquivista no Brasil", que contém os trabalhos apresentados na I Reunião Brasileira de Ensino de Arquivologia (Rebrarq). O evento realizado em 1995 e o livro representam o primeiro trabalho dedicado à formação profissional do arquivista brasileiro. Foi deste evento que foi realizado mais tarde a I Reunião Brasileira de Ensino e pesquisa em Arquivologia com o intuito de dar continuidade à discussão iniciada em 1995.

Segundo Duranti (2003),

[...] em outros tempos eram discutidos como os cursos de arquivolgia se preocupavam com a qualidade dos suportes dos documentos (como por exemplo, a acidez do papel) e o volume crescente dos mesmos. Desta maneira todos os cursos eram voltados para a conservação de documentos.

A educação era baseada na identificação, ordenação e descrição de documentos antigos e a maioria dos professores não acreditavam que esse paradigma mudaria, pois não acreditavam na necessidade de uma investigação teórica dentro da arquivologia (DURANTI, 2003, p.72, tradução nossa) ${ }^{1}$.

Mas, esse paradigma mudou, e a discussão sobre os usuários em arquivos começou na década de 1960, sendo discutido em três grandes eventos: Conselho Internacional de Arquivos: o Congresso Extraordinário, realizado em Washington, em 1966; a X Conferência da TableRounde, que ocorreu em Copenhagen, em 1967; e o VI Congresso Internacional, que aconteceu em Madri no ano de 1968 (SILVA et al., 1998). E ganhou força na década seguinte. Mas mesmo assim, duas décadas depois, a temática continuou sendo muito pouco expressiva no âmbito do conhecimento científico gerado na Arquivologia.

Diante disso, o que se vê atualmente é uma necessidade de um profissional que além dos conhecimentos técnicos da gestão de documentos saiba entender as demandas de seu público.

'DURANTI, 2003, p. 72. Original na língua inglesa. 


\section{METODOLOGIA}

Para compreender como é a atual estrutura das disciplinas da área de Estudos de Usuários nos currículos dos 16 cursos de Arquivologia no país foi realizada:

- Revisão de literatura sobre a temática na área;

- Compreensão da situação atual das disciplinas nos cursos de arquivologia do país por meio da leitura da ementa apresentada por cada curso.

- Entrevista com coordenadores dos cursos e/ou professores que ministram as disciplinas. 
Vivemos uma conjuntura histórica permeada por cenários complexos e contraditórios, especialmente no que tange às transformações no mundo do trabalho. Dentre os processos sociais e as polêmicas contemporâneas destacam-se, atualmente, aquelas envolvendo a problemática do conhecimento e da formação profissional face ao processo de reestruturação produtiva do capitalismo global.

\begin{abstract}
No caso brasileiro, as questões teóricas centrais que informam essa problemática não parecem ter sido suficientemente consideradas pelas políticas educacionais em curso no país, destacando dentre outras a atual política relativa aos currículos dos cursos de graduação que vem sendo implementada pelo Ministério da Educação (MEC), a partir da aprovação da Lei no 9.131/95 e da nova LDB (Lei no 9.394/96) (CATANI; OLIVEIRA; DOURADO, 2011, p.68).
\end{abstract}

A tecnologia tornou-se fator fundamental num contexto em que a competitividade e a produtividade se tornaram dogmas absolutos e sinônimo de luta pela sobrevivência no mundo dos negócios. Portanto, nesta ótica empresarial, verifica-se que grande parte das vantagens está associada à qualificação dos recursos humanos e à qualidade dos conhecimentos produzidos. Por isso, a questão da formação e da produção do conhecimento passou a ser de fundamental interesse das empresas, especialmente das transnacionais (CHESNAIS, 1996, p. 12).

A nova forma de operar do capitalismo é explicitada, por Harvey (1992, p. 71) em termos de um regime de acumulação inteiramente novo, associado a um sistema de regulamentação política e social bem distinto, denominado "acumulação flexível". Essa forma de acumulação surge da crise do modelo fordista (modo rígido de acumulação) e do Estado do Bem-Estar ocorrida, sobretudo, na primeira metade da década de 1970. A recessão, a crise fiscal e de legitimidade criaram oportunidades para a reestruturação econômica e o reajustamento social e político. As décadas de 1970 e 1980 foram palco da intensificação da competição global, o que levou

[...] a um período de racionalização, reestruturação e intensificação do controle do trabalho [...]. A mudança tecnológica, a automação, a busca de novas linhas de produto e nichos de mercado, a dispersão geográfica para zonas de controle do trabalho mais fácil, as fusões e medidas para acelerar o tempo de giro do capital passaram ao primeiro plano das estratégias corporativas de sobrevivência em condições gerais de deflação (HARVEY, 1992, p. 137 e 140).

Segundo Catani; Oliveira e Dourado (2001, p. 70), o mercado de trabalho sofre uma radical transformação, valendo-se de regimes e de contratos de trabalho mais flexíveis através, por exemplo, da adoção do trabalho em tempo parcial, temporário ou subcontratado. Para Harvey (1992, p. 142), esse novo modo de operar do capitalismo não significa, no entanto, que ele esteja ficando mais "desorganizado". Pelo contrário,

[...] o capitalismo está se tornando cada vez mais organizado através da dispersão, da mobilidade geográfica e das respostas flexíveis nos mercados de trabalho,nos processos de trabalho e nos mercados de consumo, tudo isso 
acompanhado por pesadas doses de inovação tecnológica, de produto e institucional (HARVEY, 1992, p. 150-151).

Tal organização vem sendo alcançada, em especial, através do acesso e controle da informação, mercadoria valiosa, especialmente na propagação do consumo e desenvolvimento de atividades no sistema financeiro global; do acesso e controle do conhecimento científico e técnico, de importância vital na luta competitiva. O conhecimento tornou-se também mercadoria chave no estabelecimento de vantagem competitiva e, por isso, vem sofrendo processos mais acentuados de subordinação ao capital.

A discussão do mercado de trabalho, especialmente da formação de profissionais, parece perder completamente o sentido quando nos deparamos com uma sociedade que se encaminha rapidamente para o "fim dos empregos". Afirma Rifken (1995) que o mundo se dirige para um declínio inevitável dos níveis de emprego e para uma redução da força de trabalho. O desenvolvimento tecnológico ocasionou a terceira revolução industrial e permitiu mudanças revolucionárias no processo produtivo e organizacional da produção, constituindose no grande aliado dessa eliminação dos empregos. O declínio da força de trabalho global é registrado na indústria, na agricultura e até no setor de serviços. As mudanças tecnológicas ampliaram a produtividade, aumentaram os lucros e diminuíram os empregos. A exceção acentuada por Rifken (1995) com relação à redução da força de trabalho global encontra-se no setor do conhecimento.

De acordo com Catani, Oliveira e Dourado (2001, p. 72), na ótica empresarial tem prevalecido o entendimento de que os novos perfis profissionais e os modelos de formação exigidos atualmente pelo paradigma de produção capitalista podem ser expressos, resumidamente, em dois aspectos: polivalência e flexibilidade profissionais. Isto estaria posto, com maior ou menor intensidade, para os trabalhadores de todos os ramos e para todas as instituições educativas e formativas, especialmente as escolas e as universidades.

Esse mesmo ideário é elemento basilar das reformas na educação superior, sobretudo, a partir do primeiro mandato do Governo Fernando Henrique Cardoso (19951998), consubstanciado na LDB (Lei no 9.394/96), que tem a flexibilidade e a avaliação como eixos articuladores da reconfiguração deste nível de ensino (CURY, 1997).

De acordo com Dourado e Oliveira (1999), a questão sobre as reformas nos currículos de graduação aumentou a partir de 1995. Dentre os principais elementos que desencadearam essa movimentação na área estão:

a) a Lei no 9.131/95 que, ao criar o Conselho Nacional de Educação (CNE), definiu como uma das competências desse órgão deliberar sobre as Diretrizes Curriculares propostas pelo MEC, para os cursos de graduação (letra "c" do parágrafo $2^{\circ}$ do art. $9^{\circ}$ ); 
b) a nova LDB que, no inciso II do artigo 53, cria a necessidade de Diretrizes Curriculares para os cursos de graduação e permite a eliminação dos chamados "currículos mínimos", tornando os currículos de graduação mais flexíveis;

c) a intensificação das discussões internacionais e nacionais sobre diplomas e perfis profissionais, face as mudanças na sociedade contemporânea e,particularmente, no mundo do trabalho:

d) o processo desencadeado pela Secretaria de Educação Superior (SESu) do MEC, em 1997, objetivando a implementação das Diretrizes Curriculares para os cursos de graduação;

e) a definição de "Padrões de qualidade para os cursos de graduação", pela SESu;

f) o estabelecimento de critérios sobre a constituição de comissões e procedimentos de avaliação e verificação de cursos superiores;

g) o posicionamento assumido pelo Fórum de Pró-Reitores de Graduação, especialmente no "Plano Nacional de Graduação" em prol de Diretrizes Curriculares gerais e fortalecimento dos projetos pedagógicos institucionais nos cursos de graduação.

O projeto do Ministério da Educação era adaptar os currículos às mudanças dos perfis profissionais. Para isso foram adotados alguns princípios orientadores para as mudanças curriculares na graduação: a) flexibilidade na organização curricular; b) dinamicidade do currículo; c) adaptação às demandas do mercado de trabalho; d) integração entre graduação e pós-graduação; e) ênfase na formação geral; f) definição e desenvolvimento de competências e habilidades gerais. Em suma, o objetivo geral que vem orientando a reforma é, justamente, "[...] tornar a estrutura dos cursos de graduação mais flexível" (BRASIL,1996). Ao mesmo tempo, o CNE aprovou, em 3 de dezembro de 1997, o Parecer no 776/97 que trata da "[...] orientação para as diretrizes curriculares dos cursos de graduação" (BRASIL, 1997).

Neste documento, o Conselho assume posição em favor da eliminação da 'figura dos currículos mínimos', que teria produzido 'excessiva rigidez' e 'fixação detalhada de mínimos curriculares', especialmente no que tange ao "excesso de disciplinas obrigatórias" e ampliação desnecessária do tempo de duração dos cursos (CATANI; OLIVEIRA; DOURADO, 2001, p. 74).

Portanto, as Diretrizes Curriculares devem garantir ampla liberdade para as definições dos currículos plenos.

A Universidade de São Paulo (USP) e a Universidade Federal de Minas Gerais foram pioneiras no início de elaboração de processo de elaboração de diretrizes curriculares gerais para a reformulação de seus cursos de graduação. Atualmente várias outras instituições federais vêm propondo uma maior flexibilização dos seus cursos de graduação.

Segundo Catani, Oliveira e Dourado (2001, p. 71) é importante destacar que: 
[...] discussões sobre a identidade institucional e sobre os projetos e processos de formação das IES, particularmente das universidades, a questão da flexibilização curricular era vista como possibilidade de 'oxigenação' dos componentes curriculares e, consequentemente, como expressão do projeto acadêmico de formação de cada IES, não se reduzindo às demandas e parâmetros do mercado (CATANI; OLIVEIRA; DOURADO, 2001, p. 77).

Baseados nesta ótica, os estudos sobre reformulação curricular devem traçar parâmetros norteadores que levem a uma reflexão social sobre a formação profissional e a indissociabilidade no âmbito acadêmico entre ensino, pesquisa e extensão.

O curso de arquivologia e o profissional arquivista também sofreram todos os impactos devido às transformações ocorridas na sociedade nas últimas décadas. A reflexão sobre sua funções, novas habilidades necessárias para atender a uma nova demanda social são temas recorrentes em pesquisas da área. Este processo tem ainda como objetivo final o auto reconhecimento e consolidação da disciplina arquivística como campo científico. Buscando não mais apenas o desenvolvimento das práticas, mas a reflexão de um pensamento sobre as práticas.

\subsection{A FORMAÇÃO DO ARQUIVISTA NO CENÁRIO INTERNACIONAL}

Há mais de 100 anos, três arquivistas holandeses, Samuel Muller, Johan Feith e Robert Fruin, publicaram umas das obras consideradas fundamentais para o desenvolvimento da arquivologia, o "Manual de arranjo e descrição de arquivos" . Em mais de um século, a arquivologia confrontou-se com profundas modificações, em especial nas últimas quatro décadas, resultantes de novos parâmetros de produção, circulação e uso da informação arquivística. Tais modificações vêm implicando redefinições diversas nos marcos teóricos da disciplina, nos serviços de informação arquivística, e na formação do arquivista. Nessa perspectiva, segundo Michael Cook as "tradições" ou modelos de ensino, no âmbito internacional, podem ser classificadas em cinco categorias: a tradição européia, a tradição ítalo-hispânica, a tradição britânica, a tradição norte-americana e aquelas dos países em desenvolvimento, em que, apesar de uma homogeneidade, possuem também algumas características específicas.

"Antes do século XIX, a arquivologia era uma ciência empírica, a serviço da organização dos arquivos para fins administrativos" (DUCHEIN, 1993, p. 19). Com o incremento da pesquisa histórica do século XIX, ela passou a ser uma ciência auxiliar da história. A origem de um ensino sistemático de arquivologia situa-se nesse período (primeira metade do século XX na Europa. Portanto, foi nas escolas europeias que a arquivologia se 
desenvolveu enquanto ciência (GAGNON-ARGUIN, 1992, p. 207). Em seguida, influenciada pelas grandes mudanças socioeconômicas do começo do século $X X$, ela se tornará novamente uma ciência auxiliar da administração. E, finalmente, com o movimento da sociedade da informação, fundada sobre a criação e domínio do saber, caracterizada pela rapidez, pela inovação e pelo efêmero, desencadeará a tomada de consciência de sua missão e de sua própria definição (JARDIM; FONSECA, 1999, p. 10). Segundo Menne-Haritz, a passagem da arquivologia de "ciência descritiva" para "ciência multifuncional" conduzirá sua transformação como ciência ligada às ciências da informação (MENNE-HARITZ, 1992, p. 9).

A tradição do ensino europeu foi estruturada, de acordo com a sua gênese, na história e suas ciências auxiliares. A primeira escola criada data de 1811, a Scuola di archivistica (Itália / Nápoles). Dez anos depois duas escolas são fundadas: a Escola des Chartes (França) e a Bayerische Archivschule (Alemanha). Outro ponto representativo se refere ao papel pioneiro do Estado italiano na pedagogia arquivística. Diversas "scuola di archivistica" emergiram a partir da segunda metade do século XIX: em Veneza (1854), em Palermo (1855), em Florença (1856), em Genova (1873), em Parma (1876), em Roma (1878) e em Roma Pontifícia (1884) - o futuro Estado do Vaticano (MATOS, 2011, p. 2). Na mesma linha, final do século XIX, segundo Menne-Haritz (1996, p. 57), registra-se a origem da Marburg Archivschule, que dá início à profissionalização dos arquivos na Alemanha.

Atualmente, de modo geral, todos os países europeus oferecem programas de ensino universitário de arquivologia. Esses estabelecimentos são, em sua maioria, autônomos (independentes das universidades), e financiados por seus governos, com o objetivo de formar o quadro integrado pelas instituições públicas.

Dentro dessa ótica, duas tendências emergiram. A primeira baseada na concepção de uma arquivologia histórico-erudita, na qual os conhecimentos são dirigidos grandemente para a história e suas ciências auxiliares. A segunda seguiu a corrente de uma arquivologia bibliodocumental, enfatizando as problemáticas concernentes à informação contemporânea, como, por exemplo, o controle da produção de documentos (JARDIM; FONSECA, 1999, p. 11). A primeira reunindo os arquivistas, profissionais encarregados dos arquivos permanentes, na qual os conhecimentos são dirigidos, grandemente, para a história e suas ciências auxiliares. $\mathrm{Na}$ segunda, situam-se os records managers, profissionais encarregados da gestão de documentos. A formação desses profissionais enfatiza as questões concernentes ao controle da produção de documentos. Tal cisão vai muita além do que poderia qualificar como problemas corporativos e profissionais. De fato, observa-se a separação entre a Arquivologia e a Gestão de Documentos (MATOS, 2011, p. 3).

Na tentativa de superar essa cisão, os canadense, e mais especificamente no Canadá francês, no Québec, formula-se o conceito de uma "arquivística integrada" que segundo Rousseau e Couture (1994) "[...] tem como objetivo ocupar-se simultaneamente do valor 
primário e do valor secundário do documento". A formação arquivística ministrada pela École de Bibliothéconomie et des Sciences de l'Information (Ebsi), da Université de Montréal baseiase nessa abordagem.

A tradição arquivística latino-americana remonta ao século $\mathrm{XVI}$, no momento da colonização espanhola e portuguesa (TANODI apud JARDIM; FONSECA, 1999, p. 20). Tanodi considera que o desenvolvimento das instituições de arquivo e do pessoal responsável pela organização desses estabelecimentos pode ser dividido em três fases.

A primeira é denominada período colonial espanhol e português, perpassa os séculos XVI, XVII, XVIII, além do primeiro decênio do século XIX. A segunda pode ser definida como uma época de forte emancipação, de consolidação nacional e de desenvolvimento republicano abrangendo o século XIX e a primeira metade do século XX. E, finalmente a terceira, prolonga-se até o momento atual (TANODI apud JARDIM; FONSECA, 1999, p. 20)

Em um primeiro momento, as administrações legislativa, executiva e judicial dos territórios de além-mar foram regidas pelos reis da Espanha e de Portugal. Isso significava que os procedimentos utilizados (teóricos e práticos) eram estabelecidos segundo as bases legais, as tradições e os costumes da península hispano-portuguesa. O pessoal responsável pela produção, conservação e arquivamento dos documentos era composto por secretários ou tabeliães. Esse papel Ihes concedia, de acordo com a legislação e a cultura importada da metrópole, o direito de impor taxas de serviço. A experiência requerida para a prática dessas funções fundamentava-se na prática documental transmitida às gerações. Ao longo do tempo, algumas mudanças práticas foram estabelecidas para atender melhor às necessidades da administração local. No fim do século XVIII, o desenvolvimento educacional e o papel importante que teve a igreja católica fizeram com que fosse atribuído "naturalmente" ao clero, além das suas diversas responsabilidades, a missão de organizar seus próprios documentos. Essa missão fundamentava-se sobre as tradições e experiências do mundo europeu. No entanto com o tempo os conhecimentos empíricos deram margem ao reajuste de alguns procedimentos (JARDIM; FONSECA, 1999, p. 20).

Num segundo tempo, o poder exercido pelas coroas espanhola e portuguesa foi substituído por novas autoridades locais, dando origem a 20 países, no mundo hispanoamericano. Criados sobre princípios democráticos, os Estados independentes terão uma organização política dividida entre os poderes legislativo, executivo e judiciário. Essas mudanças ocasionaram grandes modificações, principalmente no que se refere à produção de documentos. "Paralelamente, o desenvolvimento do tratamento dos documentos e dos arquivos foi ampliado graças ao "savoir-faire" de outros países europeus, assim como o do Estados Unidos" (TANODI apud JARDIM; FONSECA, 1999, p. 21). 
Um terceiro período caracteriza-se pela continuidade da fase precedente e a implantação, propriamente dita, do ensino. Os métodos se revelavam arbitrários no âmago das administrações e, assim, o acesso aos arquivos permanecia restrito.

\footnotetext{
Podemos constatar que houve uma penetração progressiva de princípios teóricos e práticas arquivísticas a partir de 1940, para atender os novos métodos da pesquisa histórica, onde enfatizavam-se os métodos quantitativos e qualitativos. Assistimos, também, nessa época a algumas reformas administrativas (JARDIM; FONSECA, 1999, p. 21).
}

A comunidade latino-americana tem demonstrado uma preocupação constante com o ensino dos profissionais de arquivo. A Associación Latino Americana de Archivos (ALA) organizou diversos colóquios sobre o tema; dentre eles destacamos os de 1980, no Rio de Janeiro (Brasil), e 1981, em Buenos Aires (Argentina). Além disso, no final de 1995, encontros nacionais de professores universitários de arquivologia desenvolveram-se no Brasil e na Argentina (JARDIM; FONSECA, 1999, p. 24).

$O$ ensino de arquivologia apresenta-se abrangente e sólido, propondo uma interrelação entre as duas tendências, o que resultou em uma arquivologia integrada. Essa abordagem exprime, claramente, a harmonização dos dois modelos tradicionais de ensino. No entanto, a explosão das tecnologias de informação provocou uma instabilidade no que se refere aos papéis tradicionais do arquivista. Alguns esforços foram empreendidos a fim de promover debates sobre a identidade profissional dos arquivistas, porém essa questão ainda permanece irresoluta no continente europeu. E é por isso que, no momento da unificação européia, segundo René Bazin, "[...] seria prematuro falar de um arquivista europeu [...]" (RENÉ-BAZIN, 1992, p. 227).

Nos Estados Unidos, o "Relatório Bermis", considerado o mais importante da arquivística americana, recomendava um ensino de acordo com as tradições européias. Este relatório fazia uma crítica aos bibliotecários, dizendo que não estariam aptos a cuidar dos arquivos, o que incitou a inclusão de disciplinas de natureza arquivística nas escolas de biblioteconomia. O primeiro programa oferecido foi o da University of Columbia, em 1938 (JARDIM; FONSECA, 1999, p. 13).

Durante os anos 40, 50 e 60 diversos debates concentraram-se em analisar o lugar onde seria mais vantajoso situar o ensino da arquivologia. Isto é, a que área deveríamos vincular o ensino de arquivologia no meio universitário. Nos departamentos de história, e formar historiadores-arquivistas ou nas escolas de biblioteconomia e formar bibliotecáriosarquivistas? Três pesquisadores participaram dessa discussão: H.C. Jones e T.R. Schellenberg, ambos arquivistas, além de John C.Colson, professor de biblioteconomia na University of Maryland (SCHELLENBERG apud JARDIM; FONSECA, 1999, p. 13). 
Para H.C. Jones , a única possibilidade seria incorporar a arquivística enquanto uma disciplina do programa de biblioteconomia, da American University. Segundo ele, os arquivistas haviam perdido a ocasião de integrar as duas tendências. Ele defendia a ideia de uma arquivologia unificada, como indica o título da disciplina que ele propôs: "História e administração dos arquivos". Paradoxalmente a sua opinião final foi que o lugar mais viável para a formação dos arquivistas era nos departamentos de história. Quanto a Schellenberg, ele afirma que "[...] apesar dos princípios e das técnicas de ambas as profissões serem distintas, existe, igualmente, uma certa complementaridade. $\mathrm{E}$ os objetivos das duas profissões são, obviamente, os mesmos: tornar disponíveis os recursos de pesquisa do país". Segundo Schellenberg, os arquivistas tem muito a aprender da biblioteconomia, visto que ela comunga do mesmo objeto de estudo que a arquivologia, isto é, a informação. Mas é evidente que cada um tem uma identidade, que agrupa seus princípios, métodos e sua terminologia. Ele conclui afirmando que a melhor solução seria localizar a arquivologia nas ciências da informação (JARDIM; FONSECA, 1999, p. 14).

Já Colson questiona de que forma as escolas de Biblioteconomia e Ciência da Informação poderiam integrar o ensino dos bibliotecários e dos aqruivistas, partindo do princípio de que se trata apenas de eixos conexos. Poderia existir segundo ele, um corpo comum e duas especializações independentes (JARDIM; FONSECA, 1999, p. 14).

Nos Estados Unidos a maioria dos programas oferecidos está ligada a escolas de Biblioteconomia e Ciência da Informação. E todos os diplomas são concedidos através do mestrado.

Essas contradições apresentadas nos modelos de formação do arquivista nos diversos países, continua nos dias atuais. Assumindo hoje um caráter de afirmação da arquivologia como campo científico. Estes diversos modelos nos levam a uma reflexão sobre qual tipo de profissionais as universidades querem formar, e que tipo de profissional o mercado precisa. Na verdade o que é possível perceber é que a formação universitária deve estar em harmonia com o mercado e com as suas necessidades regionais específicas.

\subsection{DEFICIÊNCIAS NA FORMAÇÃO DO ARQUIVISTA}

A regulamentação da profissão de arquivista ocorreu há 37 anos e percebe-se que hoje há uma busca para entender que tipo de profissional a sociedade necessita. Segundo Souza (2011, p. 14), "[...] em princípio, o mercado deveria demonstrar uma simbiose com os espaços de formação, mas os arquivistas apresentaram, como tema recorrente, a necessidade de adequação do currículo, sobretudo com um enfoque centrado nas novas tecnologias." 
A profissão de arquivista surgiu inicialmente para facilitar o acesso aos documentos, à informação, ainda que sua função estivesse vinculada fundamentalmente à custódia de documentos, sendo, inclusive reconhecida como homem-arquivo ou arquivo-historiador (DUCHEIN, 1991). Segundo Peter Horsman:

[...] um arquivista não é exatamente um profissional da informação: o trabalho arquivístico não é exatamente dar acesso à informação senão dar acesso ao registro, à prova. E isso é mais que informação. Isso é prova registrada das atividades dos organismos públicos ou das organizações privadas (HORSMAN, 2002, p.48).

De acordo com Souza (2011), nas últimas décadas do século XX, as investigações sobre os arquivos se ampliaram, e se converteram em objeto de análise de pesquisadores $e$ estudiosos em geral. Alguns resultados dessas investigações sobre os arquivos revelam que:

- O número de pesquisadores nos arquivos é reduzido;

- A política de informação está pouco desenvolvida na maioria deles;

- A questão da transmissibilidade da informação é um problema não solucionado;

- Ocorre uma tendência de quebra de paradigma dos arquivos como meros lugares de custódia em benefício de um paradigma informacional;

- A atividade profissional dos arquivistas adota como função fundamental, a valorização do objeto físico da informação, do suporte, ainda que nos últimos anos o concurso da tecnologia da informação venha provocando alterações neste sentido.

Estes resultados assinalam mudanças na arquivologia e levam os profissionais e pesquisadores da área a repensarem sobre seu papel na atual sociedade. Neste trabalho pretende-se abordar também a representação da arquivologia na sociedade, baseada na formação profissional representada pelos cursos de graduação e o que o mercado de trabalho e a sociedade de forma geral espera desse profissional. Pretende-se ainda investigar a existência de uma homogeneidade nos currículos de formação em arquivologia e analisar a incidência de disciplinas voltadas para os estudos de usuários

Segundo Murilo Cunha "[...] uma profissão existe porque existe uma necessidade social que deve ser cumprida" (CUNHA, 1981, p. 155). Logo, pode-se entender que também a arquivologia tem seu papel perante a sociedade, as profissões são legitimadas pelo trabalho que prestam a uma comunidade, e esta Ihe devolve o reconhecimento.

Como já foi mencionado anteriormente, as atividades práticas desenvolvidas pelos arquivistas estão reconhecidas desde 1978, e sofreram poucas modificações. As atribuições previstas na legislação propõem o tratamento dos arquivos nas três fases (arquivos correntes, intermediários e permanentes). Atualmente o que se encontra no mercado de trabalho são atividades ligadas às práticas inerentes à gestão de documentos, o que revela uma grande 
preocupação com o tratamento dos documentos, mas também com o seu acesso. $O$ arquivo trata os documentos para que eles possam ser disponibilizados. Os profissionais também trabalham com esta preocupação, mas a questão a ser tratada aqui é se os currículos vigentes hoje nas instituições de ensino que oferecem a formação em arquivologia atendem a esta necessidade. No âmbito acadêmico, conforme Bellotto,

\begin{abstract}
[...] muitos dos especialistas que têm se preocupado com a formação e o desenvolvimento profissional do arquivista, em âmbito internacional são unânimes em reconhecer as deficiências da formação, falta de relação entre o mercado de trabalho e o mundo universitário, assim como apontar as fraquezas internas da profissão advindas não só da debilidade de formação, mas também da carência da maior consolidação das teorias, das normas, da evolução vertiginosa das novas tecnologias não acompanhada pelo mesmo ritmo no ensino e aprendizagem. (BELLOTTO, 2004, p. 24).
\end{abstract}

Percebe-se então que uma maior diálogo entre as associações profissionais e universidades, seria uma caminho, que já foi apontado por Souza (2011), para fechar as lacunas ainda existentes nos currículos de formação dos cursos. Essa aproximação permitiria uma compreensão mais precisa e eficaz das mudanças do quadro social, e consequentemente sobre a influência que essas mudanças podem provocar nos arquivos, exigindo por vezes, uma nova postura profissional, ou um novo pensamento sobre as práticas já existentes.

Bellotto $(2004$, p. 2) ainda destaca as capacidades necessárias à profissão:

Quando se fala do arquivista para o século XXI, esperando dele que se assenhore das novas tecnologias para um eficiente desempenho de seu trabalho, não nos esqueçamos que não se pode prescindir daquelas qualidades esperadas de tal profissional, em qualquer situação, tempo e lugar- com ou sem tecnologia. Alguns especialistas assim as tem arrolado: 1. Capacidade de análise e síntese, juntamente com uma aptidão particular de esclarecer situações complexas e ir ao essencial; 2. Habilidade de formular claramente suas ideias, tanto de forma escrita quanto verbal; 3 . Capacidade de julgamento seguro; 4 . Aptidão para tomar decisões sobre questões ligadas à memória da sociedade; 5 . Abertura às novas tecnologias da informação; 6 . Bom senso para tomar resoluções; 7. Adaptação à realidade, às condições de seu tempo e lugar (Grimard, 1993). E, como se tudo isso fosse pouco, falase, ainda, nas qualidades de adaptabilidade, pragmatismo, curiosidade intelectual, , rigor, método, continuidade, capacidade de compreensão e de escuta relativamente ao produtor, ao pesquisador e ao cidadão. (BELLOTTO, 2004, p.2)

A partir dos apontamentos da autora é possível notar principalmente a capacidade de adaptação do profissional tanto nas questões tecnológicas, acompanhando os seus avanços, mas também sem ignorar o que já foi feito, respeitando sempre o contexto social e econômica em que a instituição a qual serve está inserida. Sua flexibilidade juntamente com a sua capacidade de escutar devem estar principalmente direcionadas aos usuários, no momento da realização do atendimento presenciais ou virtuais. Essas habilidades serão extremamente favoráveis para a elaboração de novos serviços ou para a melhoria do serviços já existentes. 
Heloísa Belloto também destaca as considerações do arquivista sueco Berndt Fredriksson, em que ele descreve o papel do arquivista na sociedade contemporânea:

O papel dos arquivistas na sociedade contemporânea, definitivamente está mudando. Ele torna-se mais amplo e torna-se mais proativo em relação ao resto da sociedade. Isto significa que temos a capacidade de antecipar mudanças e caminhar com ela. Ele insiste em que nós, arquivistas, temos um papel a desempenhar na sociedade do conhecimento. Mas, primeiro precisamos definir mais detalhadamente o que queremos que nosso papel seja. Fazendo isto teremos convencido o resto do mundo sobre a nossa competência, isto porque na sociedade contemporânea o profissionalismo arquivístico tem um papel essencial a desempenhar (BELLOTTO, 2004, p.5).

A questão da invisibilidade dos arquivos diante da sociedade, da falta de conhecimento da sociedade, principalmente do cidadão comum sobre os serviços dos arquivos, se dá na maioria das vezes pela falta de posicionamento do profissional, que deve se mostrar aberto e atento ás necessidades de todos os tipos de consulentes, sejam eles pesquisadores habilidosos, estudantes, pesquisadores curiosos, ou o popular que desconhece as formas de utilização das ferramentas de busca e recuperação da informação, ou antes da utilização das ferramentas, não conseguiram elaborar de forma clara o seu problema de pesquisa.

\subsection{O ARQUIVISTA}

De acordo com Bellotto (2002, p.1):

O objetivo da arquivologia é o acesso à informação, desde aquela que é imprescindível para o processo decisório e para o funcionamento das atividades governamentais e/ou das de uma empresa privada ou pessoa física, assim como a que atua como testemunho dos direitos do cidadão, até a que visa à crítica e 'explicação' das sociedades passadas pela historiografia, tanto quanto a que permanece como componente de um corpus informacional que possibilite a transmissão cultural de geração a geração. (BELLOTTO, 2002, p.1).

A partir desses aspectos é que deve se delinear as características e habilidades ideais para o arquivista na sociedade contemporânea. Uma definição puramente técnica não é mais suficiente, sendo necessária a ampliação de suas funções, que devem estar voltadas tanto para a preservação, quanto para a difusão.

O termo "arquivista" remonta ao surgimento dos arquivos. No entanto, a literatura arquivística apresenta alguns conceitos que definem o arquivista e seu exercício laboral. $\mathrm{O}$ código de ética profissional proposto pelo Conselho Internacional de Arquivos (CIA) o define como "[...] todo aquele que atua no controle, no cuidado, conservação e administração de documentos" (1996, p. 1). Segundo Duchein (1999), 


\begin{abstract}
[...] o arquivista é um gestor da informação e todas as suas tarefas estão orientadas para satisfazer as necessidades informativas, de modo que a administração desenvolva suas funções com rapidez, eficiência e economia, para salvaguardar direitos e deveres das pessoas, conteúdos nos documentos, e para fazer possíveis a pesquisa e a difusão cultural. Em resumo, é um instrumento para o bom funcionamento de qualquer organização, cuja tarefa- a gestão dos recursos informativos dos documentos- resulta tão vital como a gestão dos recursos humanos, financeiros e materiais (DUCHEIN, 1999, p. 13-14).
\end{abstract}

Nesta definição de Durchein fica evidente a função social do profissional arquivista não somente na difusão e no acesso à informação, mas também de garantir o exercício de cidadania quando garante o cumprimento dos direitos e deveres das pessoas. Algumas definições por vezes apontam para um viés tecnicista da profissão, mas dentro das atividades desenvolvidas pelos profissionais, elas não são mais suficientes. A organização ou o tratamento dos documentos é essencial dentro do sistema de arquivo, mas não é suficiente para caracterizar a arquivologia e sua função.

A vinculação no passado da arquivologia com a história favoreceu a elaboração de um perfil de arquivista como guardador de documentos. Em 1993 Duchein rejeita essa ideia e diz que,

\begin{abstract}
Uma formação puramente histórica já não é certamente, suficiente para exercer a profissão de arquivista, sobretudo se dispõe a gerenciar arquivos modernos. Por outro lado, um arquivista não pode deixar de ter uma boa base histórica concernente, no mínimo, à instituição ou às instituições nas quais vai classificar os arquivos. [...] A formação profissional ideal do arquivista deve então unir, e não contrapor, os dois aspectos- 'histórico' e 'modernista'. (DUCHEIN, 1993, p. 28-29).
\end{abstract}

Então o que se busca hoje na arquivologia é uma união com os conhecimentos históricos e não uma subordinação à história. O Arquivo Nacional do Brasil, em sua terminologia arquivística o define como "[...] profissional de nível superior, com formação em arquivologia ou experiência reconhecida pelo estado" (ARQUIVO, 2004, p. 19). Ao longo do tempo o profissional experimentou alterações em suas atribuições. Além da sua função como gestor, Souza (2011, p. 51), destaca que "[...] além disso exerce uma função social que se inicia desde o momento da produção documental e se estende a todos os usuários". Novamente fica destacada a função social que está associada às funções de gestão de documentos.

Dentre as atribuições ao profissional arquivista definidas pela Lei 6.546, de 4 de julho de 1978, que regulamenta a profissão, existe um item que revela mais uma vez o trabalho integrado entre o profissional arquivista e a comunidade ao qual atende, que se segue: "[...] desenvolvimento de estudos sobre documentos culturalmente importantes" (BRASIL, 1978). Este item reafirma a necessidade do arquivista desenvolver não apenas um trabalho técnico, 
mas necessita de dominar conceitos sobre cultura, memória e patrimônio para que possa ter a sensibilidade necessária para tratar e conservar documentos importantes para a manutenção de processos e costumes de uma comunidade.

A Sociedade dos Arquivistas Americanos (SAA) em suas diretrizes de procedimentos e condutas dos arquivistas destaca o esforço que o profissional deve empenhar para garantir o acesso aos usuários de arquivos e que ainda devem se esforçar para "[...] informar aos usuários sobre a existência de pesquisas paralelas realizadas por outros pesquisadores com a utilização dos mesmos materiais, e se os indivíduos referidos concordarem, fornecerem seus nomes para outros pesquisadores" (SAA). Neste caso o arquivista além de garantir o acesso funciona como um mediador entre pesquisadores, fomentando o avanço de pesquisas nas mais diversas áreas de conhecimento. Em Portugal a Associação Portuguesa de Documentação e Informação na Saúde (APDIS), Associação Portuguesa de Bibliotecários, Arquivistas e Documentalista (BAD), e a Associação Portuguesa para o Desenvolvimento da Informação Científica e Técnica (INCl-TE) firmaram um código de ética profissional em 1999 que coloca como dever central do profissional o serviço ao usuário. Além da difusão da informação, segundo Souza (2011, p. 69), os arquivistas "[...] revelam-se também como investigadores, na reconstituição da memória social."

Ainda destacando a missão social do arquivista, a Associação de Arquivistas Quebequenses (AAQ) considera três ações fundamentais:

- Contribuir para a manutenção e o desenvolvimento da democracia assegurando que o acesso aos cidadãos seja protegido;

- Contribuir para a constituição/construção da memória coletiva;

- Assegurar que a memória coletiva seja parte integrante da cultura da sociedade. A arquivologia passa por uma mudança de paradigma que segundo Souza (2011),

[...] se anteriormente o perfil exigido era eminentemente técnico, inclusive com a primazia de uma função de guardador da informação, atualmente os arquivistas além das qualidades apresentadas, devem ter um perfil com competência para as tecnologias da informação e atuar, fundamentalmente, como disseminadores das informação. (SOUZA, 2011, p. 76)

Não deve haver portanto, uma separação entre acesso e gestão documental, entre custodial e pós-custodial. Deve-se destacar que o acesso é parte do processo de gestão, onde todas as diretrizes são formuladas e aplicadas a fim de disponibilizar o documento ao usuário. Criar dicotomias não colabora para o avanço dessa discussão. A conservação, a preservação, a organização, a normalização devem ser trabalhadas para que ao final de todo o trabalho técnico, as demandas dos usuários sejam prontamente atendidas. 
4.4 Áreas de atuação profissional do arquivista

Os espaços de trabalho estabelecidos, pelas instituições formadoras do profissional de arquivo estão definidos nas diversas categorias dos arquivos, seja pelo gênero documental, gênero audiovisual ou pela natureza dos acervos, arquivos médicos, de engenharia e outros. Além disso, os arquivistas também atuam nos arquivos eclesiásticos, históricos, fotográficos, contábeis e outros fundamentalmente do âmbito público, ainda que também na iniciativa privada e nos arquivos pessoais. É uma profissão que conta com um mercado de trabalho em expansão. "O profissional arquivista atua em instituições públicas e privadas, sendo capaz de interpretar e interagir com as diversas realidades organizacionais, no sentido de facultar o acesso a toda e qualquer pessoa" (SOUZA, 2011, p. 70).

De acordo com Mata Castilión (apud SOUZA, 2011, p. 70), as funções atribuídas aos arquivistas são:

- A direção de serviços de arquivos, tanto históricos como das grandes unidades administrativas, ou das seções dos arquivos centrais ou nacionais;

- A responsabilidade da política geral em matéria de arquivos;

- O desenvolvimento dos métodos de seleção de documentos;

- A planificação dos trabalhos de classificação, inventário e descrição dos arquivos;

- A coordenação dos trabalhos que se realizam nos arquivos com os serviços de administração e da investigação científica. Vásquez (1996, p. 111) diz que eles devem estar aptos a:

- Tratar e disponibilizar os documentos e a informação nele contida;

- Dirigir os arquivos e os sistemas e subsistemas de arquivo;

- Propor as especificações para a construção de arquivos e locais de arquivos;

- Exercer a docência da arquivística ou ciência da administração de documentos e arquivos.

Mas, além das atribuições, o arquivista necessita ter determinadas qualidades. Souza(2011) são estas:

- Capacidade de análise e síntese, juntamente com uma atitude particular de esclarecer situações complexas além de ir ao essencial;

- Habilidade de formular claramente suas ideias, tanto de forma escrita como verbal;

- Capacidade de juízo seguro;

- Atitude para a tomada de decisão sobre questões ligadas à memória da sociedade;

- Abertura à novas tecnologias da informação;

- Bom sentido na tomada de resoluções; 
- Adaptação à realidade, às condições de seu tempo e lugar (SOUZA, 2011, p. 26).

Tomando uma referência internacional, em Portugal, as funções de arquivista, indicadas como técnico superior de arquivo, estão registradas no Decreto-lei no 247/91 (SOUZA, 2011, p. 71) e indica que o profissional deve:

- Estabelecer e aplicar critérios de gestão de documentos;

- Avaliar e organizar a documentação dos fundos públicos e privados com interesse administrativo, probatório e cultural, tais como documentos textuais, cartográficos, audiovisuais e legíveis por máquina, de acordo com sistemas de classificação que se definem a partir do estudo da instituição produtora da documentação;

- Orientar a elaboração de instrumentos de descrição da documentação. Tais como guias, inventários, catálogos e índices;

- Apoiar ao usuário, orientando-o na pesquisa de registros e documentos apropriados;

- Promover ações de difusão, a fim de tornar acessíveis as fontes;

- Executar ou dirigir os trabalhos tendo em vista a conservação e a restauração de documentos;

- Coordenar e supervisionar o pessoal vinculado à função de apoio técnico de arquivista. Ainda no cenário internacional, o "Informe sobre los archivos de La Unión Europea ampliada: esfuerzo de La cooperación em el domínio de los archivos em Europa: plan de acción", aprovado em 2005 e elaborado por um grupo de especialistas dos países-membros da União Européia, apresenta como competência para o arquivista do século XXI:

- Conhecimento profundo dos requisitos básicos sobre a gestão dos documentos durante todo o seu ciclo de vida, incluindo a conservação preventiva;

- Capacidade de aproveitar as novas Tecnologias da Informação e da Comunicação (TIC);

- Conhecimento das estruturas orgânicas, dos procedimentos, dos sistemas administrativos e dos documentos produzidos por uma organização;

- Conhecimento acerca da história das instituições e da evolução da administração;

- Aperfeiçoamento contínuo de suas capacidades de comunicação;

- Conhecimento de duas ou mais línguas da União Européia;

- Capacidade de abertura a uma colaboração interdisciplinar com profissionais de outras áreas a nível da União Européia (SOUZA, 2011, p. 72).

De maneira geral, as oportunidades no mercado de trabalho têm se ampliado, e o reconhecimento de suas atribuições começa a mostrar um avanço significativo, principalmente nas últimas décadas. 
Souza (2011, p. 74) fez uma análise das atribuições dos arquivistas, relacionando as propostas de Rousseau e Couture (1998), e Martín-Pozuelo (2009), que propõem as funções principais dos arquivistas, que associadas às atribuições da lei, resulta no Quadro 1, apresentado a seguir:

\section{QUADRO 1}

\begin{tabular}{|c|c|c|c|}
\hline \multicolumn{4}{|c|}{ Atribuições dos arquivistas } \\
\hline $\begin{array}{l}\text { Rosseau } \\
\text { e Couture }\end{array}$ & $\begin{array}{c}\text { Martín- } \\
\text { Ponzuelo }\end{array}$ & Lei $n \circ 6546 / 78$ & análise ${ }^{\text {Nossa }}$ \\
\hline $\begin{array}{l}\text { Criar } \\
\text { Produzir }\end{array}$ & $\begin{array}{l}\text { Planejar } \\
\text { Administrar }\end{array}$ & $\begin{array}{l}\text { Planejamento, orientação e direção } \\
\text { das atividades de identificação das } \\
\text { espécies documentais e participação } \\
\text { no planejamento de novos } \\
\text { documentos e controle de } \\
\text { multicópias; planejamento, } \\
\text { organização e direção de serviços de } \\
\text { arquivo,; planejamento, organização } \\
\text { e direção de serviços ou centro de } \\
\text { documenuação e informação } \\
\text { constituídos por acervos arquivísticos } \\
\text { e mistos; planejamento, orientação, } \\
\text { acompanhamento do processo } \\
\text { documental e informativo. }\end{array}$ & $\begin{array}{l}\text { Planejamento } \\
\text { e direção/Gestão de } \\
\text { documentos }\end{array}$ \\
\hline Avaliar & $\begin{array}{l}\text { Conservar } \\
\text { Organizar }\end{array}$ & $\begin{array}{l}\text { Orientação quanto á classificação, } \\
\text { ordenação e descrição de } \\
\text { documentos; orientação quanto á } \\
\text { classificação, ordenação e descrição } \\
\text { de documentos; promoção das } \\
\text { medidas necessárias para a } \\
\text { conservação dos documentos }\end{array}$ & Conservação \\
\hline \multicolumn{4}{|l|}{ Adquirir } \\
\hline \multicolumn{4}{|l|}{ Classificar } \\
\hline \multicolumn{4}{|l|}{$\begin{array}{l}\text { Conservar } \\
\text { Preservar }\end{array}$} \\
\hline Descrever & Descrever & $\begin{array}{c}\text { Orientação quanto à classificação, } \\
\text { ordenação e descrição de } \\
\text { documentos. }\end{array}$ & Descrição \\
\hline $\begin{array}{l}\text { Difundir } \\
\text { Acessar }\end{array}$ & $\begin{array}{l}\text { Recuperar } \\
\text { Difundir }\end{array}$ & $\begin{array}{l}\text { Planejamento, organização e direção } \\
\text { de serviços de microfilmagem } \\
\text { aplicada aos arquivos; orientação do } \\
\text { planejamento da automação aplicada } \\
\text { aos arquivos; assessoramento dos } \\
\text { trabalhos de pesquisa científica ou } \\
\text { técnico-administrativa; elaboração de } \\
\text { pareceres e trabalhos de } \\
\text { complexidade sobre assuntos } \\
\text { arquivísticos; desenvolvimento de } \\
\text { estudos sobre documentos } \\
\text { culturalemente importantes. }\end{array}$ & $\begin{array}{l}\text { Planejamento } \\
\text { e direção/Difusão }\end{array}$ \\
\hline
\end{tabular}

Fonte: SOUZA, 2011, p. 74 
De acordo com Souza (2011, p. 74),

[...] a análise revela que o foco das práticas arquivísticas, que difere da visão custodial dos arquivos inicialmente criados, é a gestão de documentos. As atribuições equivalentes em sua amplitude são a conservação, a descrição e a difusão sendo de responsabilidade do arquivista o planejamento, a orientação e a orientação dessas atividades.

Os estudos de usuários e uso da informação arquivística estão inseridos no processo de gestão de documentos. Nessa mudança de paradigma em que o arquivo assume o papel de "difusor" da informação é que os estudos de usuários podem ajudar de forma significativa na divulgação da informação dos arquivos.

Segundo Luigi ( apud SOUZA, 2011), a profissão de arquivista evolucionou de um trabalho artesão para uma profissão baseada na preparação científica. No Quadro 2, é possível ver que, neste sentido Maria Madalena García propõe novos paradigmas para os arquivistas (SOUZA, 2011, p. 76).

QUADRO 2

Novos paradigmas para os arquivistas

\begin{tabular}{|c|c|}
\hline De: & Para: \\
\hline Análise processual & Sistêmica \\
\hline Tônica de conservação & $\begin{array}{c}\text { Avaliação (segundo modelo orgânico- } \\
\text { funcional) }\end{array}$ \\
\hline Recuperação por conteúdos & Por contextos (probatórios e funcionais) \\
\hline Papel passivo & $\begin{array}{c}\text { Intervenção ativa e direta na produção } \\
\text { dos documentos }\end{array}$ \\
\hline Conservador & Gestor da informação \\
\hline
\end{tabular}

Fonte: GARCIA, 1997

Se anteriormente o perfil exigido era eminentemente técnico, hoje as suas habilidades profissionais exigem uma competência para explorar as novas tecnologias, direcionando os recursos disponíveis para a dinamização dos serviços oferecidos nos arquivos, e atuando fundamentalmente como mediadores e disseminadores da informação.

\subsection{IDENTIFICAÇÃO DOS ESPAÇOS DE TRABALHO DO ARQUIVISTA}

Prosseguindo as reflexões sobre o novo papel do arquivista e quais habilidades são necessárias para que atendam às necessidades do mercado atual focado para a difusão da informação e não apenas da guarda, é necessário identificar os seus espaços de trabalho, buscando apontar onde são mais solicitados.

Para isto será utilizado como referencial neste trabalho, os resultados de uma pesquisa de Souza (2011), onde a autora por meio de contatos pessoais, listas de discussões, redes 
sociais e comunidades profissionais, enviou um questionário, onde se obteve 522 respostas. Este questionário tem como objetivo conhecer o universo dos arquivistas brasileiros, onde atuam, se exercem ou não a profissão, e por quanto tempo atuam. Foram gerados dados ainda sobre os espaços de formação, faixa etária e sexo dos profissionais. Neste estudo será utilizado apenas os dados sobre os empregadores e a identificação dos espaços de trabalho.

De acordo com os resultados de Souza (2011, p. 79), conforme o Quadro 3, o Estado se destaca claramente como o maior empregador, sendo que $57 \%$ dos arquivistas exercem atividades em instituições públicas, enquanto $39 \%$ o fazem em instituições privadas e $4 \%$ em outros, sobretudo em ONG.

\section{QUADRO 3}

Os espaços de trabalho

\begin{tabular}{|c|c|c|c|}
\hline $\begin{array}{c}\text { Instituições } \\
\text { Empregadoras } \\
\text { Públicas }\end{array}$ & $\begin{array}{c}\text { Instituições } \\
\text { Empregadoras } \\
\text { Privadas }\end{array}$ & $\begin{array}{c}\text { Outras Instituições } \\
\text { Empregadoras }\end{array}$ & Total \\
\hline $57 \%$ & $39 \%$ & $4 \%$ & $100 \%$ \\
\hline
\end{tabular}

Fonte: SOUZA, 2011

Para a classificação das atividades das instituições privadas, públicas e outras, Souza (2011) adotou o cadastro de empresas do Instituto Brasileiro de Geografia e Estatística (IBGE), de acordo com o Quadro 4:

\section{QUADRO 4}

Classificação das atividades dos espaços de trabalho

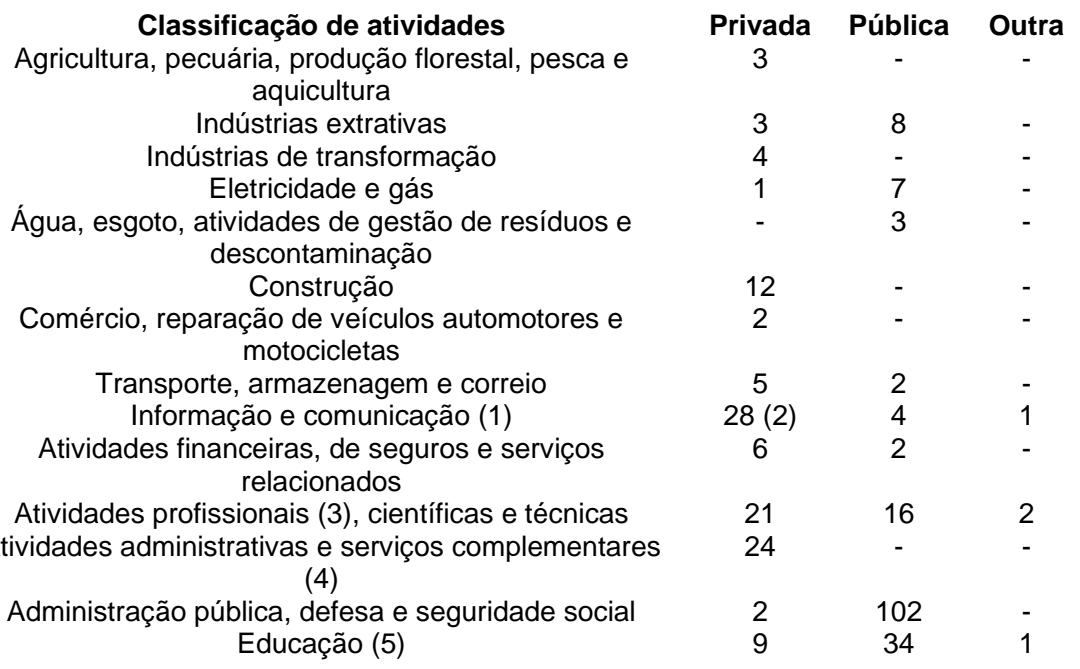


Saúde humana e serviços sociais (6)

Artes, cultura, esporte e recreação Organismos internacionais e outras instituições Fonte:.SOUZA, 2011

\section{Legenda:}

1. As empresas de engenharia, sobretudo.

2. A indicação das empresas de informação, inclusive de arquivistas, bibliotecários, para prestação de serviço de consultoria.

3. Foram indicados, sobretudo, os escritórios de advogados.

4. As empresas de consultoria foram indicadas nessa classificação.

5. As universidades federais apresentaram um percentual considerável.

6. A maior indicação foi das instituições hospitalares.

Nota: IBGE. Estatística do Cadastro Central de Empresas 2007.

De acordo com os dados apresentados nota-se que os arquivistas atuam de forma bastante significativa na administração pública, defesa e seguridade social, com 102 casos, o que caracteriza uma atribuição pública aos arquivistas. Em segundo lugar aparece a área da Educação, seguida pelas atividades de artes, cultura, esporte e lazer. Também é notório as atividades registradas em escritórios de advocacia, registradas 16 vezes. A autora destaca que alguns arquivistas deixaram de informar no questionário aplicado a denominação da instituição em que trabalham, o que impossibilitou a classificação das atividades.

Conforme os dados apresentados, os espaços de trabalho são bastante diversificados, exigindo do profissional uma flexibilidade e uma amplitude do seu conhecimento em relação ao usuário. A literatura arquivística aponta diversos tipos de usuários em um arquivo, que varia de acordo com o tipo de arquivo, se é histórico, público ou administrativo. As pesquisas de estudos de usuários convergem nesse momento para a gestão do conhecimento e gestão de documentos arquivísticos, podendo contribuir muito para o desenvolvimento de novos procedimentos específicos para cada tipo de usuário para ajudar no processo de gestão dos documentos voltadas para o acesso.

\subsection{AS REFLEXÕES SOBRE O CURRÍCULO}

Antes de aprofundar nas discussões sobre currículo no Brasil e de forma mais específica, no ensino superior de Arquivologia, torna-se necessária a compreensão das maneiras como o currículo pode influenciar não somente na formação profissional, sendo hora um objeto de construção social, hora um reflexo do ambiente social.

O currículo aparece pela primeira vez como objeto específico de estudo e pesquisa nos Estados Unidos nos anos 1920, sendo inaugurada a abordagem do tema no livro de Bobbitt, The Curriculum (1918). No discurso curricular de Bobbitt, o currículo é suspostamente 
isso: a especificação precisa de objetivos, procedimentos e métodos para a obtenção de resultados que possam ser precisamente mensurados ( SILVA, 2007, p.12).

De acordo com Silva (2007, p.13) “[...] as chamadas 'teorias do currículo', assim como as teorias educacionais mais amplas, estão recheadas de afirmações sobre como as coisas deveriam ser." Da mesma forma que pretendem "moldar" pessoas, a partir do ensino básico, podemos pensar também em seu objetivo de "moldar" profissionais, tentando alcançar um tipo desejável de profissional capaz de atender as demandas sociais. A partir das reflexões de Bobbitt busca-se um desligamento de um modelo curricular ainda derivado do Trivium e Quadrivium que fundamentaram na Idade Média, as disciplinas básicas do sistema de ensino. A partir da década de 70 inicia-se nos Estados Unidos um movimento de "reconceitualização do currículo". Silva (2007) destaca que o movimento de renovação da teoria educacional explodiu em vários lugares ao mesmo tempo. Neste sentido as teorias críticas sobre o currículo surgem para efetuar uma complexa inversão nos fundamentos das teorias tradicionais, que foram marcadas por classes dominantes manipulando o conhecimento de uma classe manipulada.

Dentro do conjunto das teorias críticas temos as teorias marxista e neo-marxista que criticam o modelo de classes dominantes e dominadas, causando abismos sociais, quando impõem de forma inescrupulosa suas ideologias (SILVA, 2007).

Em meio a essas críticas surge uma "Nova Sociologia da Educação" que traz uma preocupação com as pessoas e não apenas com o processo de conhecimento. $\mathrm{O}$ autor a define da seguinte maneira:

\begin{abstract}
A tarefa de uma sociologia do conhecimento, nessa visão, consistiria em destacar o caráter socialmente construído nas formas de consciência e de conhecimento, bem como suas estreitas relações com estruturas sociais, institucionais e econômicas. Abrangendo então uma sociologia mais geral do conhecimento. (SILVA, 2007, p.66)
\end{abstract}

Isso traz uma reflexão sobre os motivos que fazem com que certas disciplinas tenham mais prestígio que outras. Permitindo compreender qual o lugar, a relevância dos estudos de usuários nos currículos de formação da Arquivologia.

De acordo com Souza (2011), "[...] os cursos de formação iniciaram de forma tímida e nasceram com uma visão para os arquivos de caráter permanente, seguindo a tradição européia. Entretanto, hoje as funções dos arquivos se expandiram, com atuações mais dinâmicas e proativas."

Silva (2007) em seu estudo aponta outras questões sociais também muito sérias, mas que não será aprofundado nesse momento por não ser foco principal dessa pesquisa. Mas vale citar aqui as questões de sexo, gênero e raciais, que estiveram e ainda estão em constante discussão dentro das instituições de ensino. O currículo por vezes ainda provoca de maneira sutil, exclusão de minorias, mantendo resquícios do desejo de uma classe 
dominante. O que é de fato relevante é a necessidade de entender que o currículo é o caminho para a construção de pessoas bem preparadas, profissionais mais eficientes, capazes de atender às demandas sociais. Portanto, temos que entender a sua mutabilidade, a sua necessidade de jamais estacionar, de ser sempre "flexível" diante à sociedade.

De acordo com Alegbeleye (1990), as reflexões sobre os currículos na arquivologia, são importantes pois:

[...] quando investigamos o vazio entre, de um lado, as habilidades, conhecimentos, atitudes e comportamentos transmitidos nos cursos de arquivística no mundo inteiro, e a atual prática da profissão podemos vislumbrar o porquê desse vazio: uma deficiência no desenho curricular. As revisões curriculares são, portanto, urgentemente necessárias. (ALEGBELEYE, 1994 apud BELLOTTO, 2002, p. 51)

Percebe-se que o problema em ajustar o currículo com novas demandas, não é um problema exclusivo do Brasil, ocorrendo também em outros países. Para fechar as lacunas na formação profissional é preciso colocar em prática, o que já foi conquistado por meio de uma legislação favorável, que permite que cada Instituição de Ensino de Superior possa construir suas matrizes curriculares de forma autônoma e que também pode a qualquer momento que achar necessário reorganiza-lo, a fim de colocar em harmonia as necessidades do mercado de trabalho e os interesses institucionais.

\subsubsection{Harmonização}

A proposta de harmonização dos currículos de arquivologia, biblioteconomia e documentação apresentada pela Unesco em 1974, tem suas raízes em 1934 com a preocupação em torno da relação de cooperação entre as áreas apresentadas no Traité de Documetation. A Unesco as valida com a criação do ICA, em 1948; com a aproximação entre a FID e a IFLA; e com a realização da Conferência Inter-governamental sobre a Planificação das Infra-estruturas de Documentação, que marca um "pacto" entre as bibliotecas e os arquivos (MARQUES, 2011).

Marques (2011), ainda destaca um importante acontecimento em 1972 que foi o Seminário Interamericano de Integração dos Serviços de Informação de Arquivos, Bibliotecas e Centros de Documentação na América Latina e no Caribe, no âmbito da Unesco, OEA, Departamento de Estado e Comissão Nacional dos Estados Unidos para a Unesco, American Library Association e Council on Library Resources, realizado em Washington. Foram declarados os princípios, conclusões e recomendações aos governos dos países americanos, considerandose a responsabilidade do Estado em promover o acesso à informação. Nesse sentido, foi defendido: 
- o preparo de um plano nacional integrado de serviços de informação, que priorizasse a formação de pessoal voltada para o ensino comum de arquivistas, bibliotecários e técnicos em comunicação social;

- o preparo de um plano nacional de desenvolvimento dos serviços de informação, compatível com os planos regionais e internacionais, retomando o planejamento de Estruturas Nacionais de Informação Científica e Técnica, organizado pela Diretoria de Educação Ibero-americana (Madri, 1970). Quanto aos arquivos, deveriam ser contemplados nesse plano os administrativos, intermediários e permanentes do setor oficial, bem como do setor privado, quando considerados de interesse público;

- o estudo da legislação vigente sobre arquivos, bibliotecas e centros de documentação que proporcionasse "um marco jurídico atualizado";

- a criação de um grupo, em cada país, que integrasse arquivistas, bibliotecários e técnicos em comunicação social para as decisões em nível nacional;

- a constituição de grupos de trabalho nacionais para a coordenação e estudos de programas-piloto relativos a técnicas e serviços auxiliares;

- e, por fim, a organização de exposições, conferências e visitas para a difusão dos serviços de informação (ARQUIVO NACIONAL, 1974).

A proposta de harmonização surge como uma preocupação em se garantir o acesso à informação, buscando "harmonizar" certas práticas dentro de arquivos, bibliotecas e centros de documentação.

O Brasil participa desse evento, no qual é proposto o NATIS, como um sistema relacionado às ações da Unesco voltadas para o entrosamento entre os arquivos e bibliotecas nas infraestruturas nacionais. O conceito NATIS objetiva ação nacional e internacional como base para uma estrutura geral que abrangerá todos os serviços, que proporcionarão assim informação a todos os setores da comunidade e a todas as categorias de usuários (MARQUES, 2011).

É importante destacar, principalmente no contexto deste trabalho, que a questão do acesso e dos usuários é destacada fortemente nesta iniciativa, demonstrando que esta não é uma preocupação recente, que outros profissionais e organismos mundiais já compreendiam a relevância do tema. Essa mudança de paradigma, de forma especial dentro da arquivologia, saindo de um paradigma de custódia para um paradigma de acesso, vem sendo anunciado e discutido em várias esferas, o que nos faz pensar novamente o porquê de um estado incipiente do tema na área? Porque uma falta de aprofundamento nos "estudos de usuários?

Marques (2011), nos apresenta um quadro bastante esclarecedor sobre a proposta de um tronco comum entre arquivologia, biblioteconomia e documentação conforme podemos observar no Quadro 5: 
QUADRO 5

Proposta de tronco comum nos estudos de documentalistas, bibliotecários e arquivistas

\begin{tabular}{|c|c|c|c|}
\hline & Documentação & Biblioteconomia & Arquivologia \\
\hline $\begin{array}{l}\text { Fundamentos(histórico, } \\
\text { desenvolvimento, } \\
\text { evolução dos } \\
\text { conceitos) }\end{array}$ & $\begin{array}{l}\text { Sociologia da } \\
\text { informação } \\
\text { História da da } \\
\text { Informação } \\
\text { Científica } \\
\text { Teoria da } \\
\text { comunicação } \\
\text { Métodos de } \\
\text { pesquisa }\end{array}$ & $\begin{array}{l}\text { A biblioteca na } \\
\text { sociedade } \\
\text { História das } \\
\text { bibliotecas e } \\
\text { educação a esse } \\
\text { respeito } \\
\text { Legislação relativa } \\
\text { às bibliotecas } \\
\text { Estudos de } \\
\text { usuários } \\
\text { Métodos de } \\
\text { pesquisa }\end{array}$ & $\begin{array}{c}\text { Organização } \\
\text { administrativa } \\
\text { (passado e } \\
\text { presente): } \\
\text { geografia histórica } \\
\text { História dos } \\
\text { arquivos } \\
\text { Legislação relativa } \\
\text { aos arquivos } \\
\text { Teoria da } \\
\text { Arquivologia } \\
\text { Métodos de } \\
\text { pesquisa }\end{array}$ \\
\hline Materiais & $\begin{array}{c}\text { Formas de } \\
\text { documentação: } \\
\text { periódicos, } \\
\text { relatórios, novas } \\
\text { mídias, bases de } \\
\text { dados } \\
\text { Serviços de } \\
\text { informação }\end{array}$ & $\begin{array}{c}\text { Formas de } \\
\text { documentação: } \\
\text { publicações, livros, } \\
\text { periódicos, novas } \\
\text { mídias } \\
\text { Ferramentas } \\
\text { bibliográficas } \\
\text { História das artes } \\
\text { do livro }\end{array}$ & $\begin{array}{c}\text { Formas de } \\
\text { documentação: } \\
\text { dossiês, registros, } \\
\text { manuscritos, } \\
\text { cartas, material } \\
\text { audiovisual, } \\
\text { dossiês legíveis } \\
\text { por máquinas, etc. } \\
\text { Categorias de } \\
\text { dossiês: públicos, } \\
\text { privados, notariais, } \\
\text { etc. } \\
\text { Sistemas de } \\
\text { registro } \\
\text { (organização dos } \\
\text { arquivos } \\
\text { intermediários) }\end{array}$ \\
\hline $\begin{array}{l}\text { Métodos (organização, } \\
\text { interpretação, } \\
\text { avaliação e utilização } \\
\text { dos materiais) }\end{array}$ & $\begin{array}{c}\text { Indexação, } \\
\text { resumos analíticos, } \\
\text { análise de } \\
\text { conteúdo, } \\
\text { armazenamento, } \\
\text { linguagens } \\
\text { documentárias e } \\
\text { sistemas de } \\
\text { pesquisa } \\
\text { documentária } \\
\text { Organização de } \\
\text { bases de dados } \\
\text { Difusão de } \\
\text { informação } \\
\text { Serviços } \\
\text { destinados aos } \\
\text { usuários }\end{array}$ & $\begin{array}{c}\text { Processos de } \\
\text { consulta } \\
\text { Organização do } \\
\text { conhecimento } \\
\text { Indexação, } \\
\text { resumos analíticos, } \\
\text { análise de } \\
\text { conteúdo } \\
\text { Serviços de leitores } \\
\text { Análise sistêmica }\end{array}$ & $\begin{array}{c}\text { Gestão de dossiês } \\
\text { e depósitos } \\
\text { intermediários } \\
\text { Triagem } \\
\text { Classificação e } \\
\text { inventário, } \\
\text { instrumentos de } \\
\text { pesquisa } \\
\text { Operações e } \\
\text { serviços } \\
\text { destinados aos } \\
\text { usuários }\end{array}$ \\
\hline
\end{tabular}




\begin{tabular}{|c|c|c|c|}
\hline $\begin{array}{c}\text { Gestão (fixação de } \\
\text { objetivos e métodos) }\end{array}$ & $\begin{array}{c}\text { Gestão e } \\
\text { administração } \\
\text { Pessoal } \\
\text { Aspectos jurídicos } \\
\text { Planificação de } \\
\text { sistemas }\end{array}$ & $\begin{array}{c}\text { Gestão e } \\
\text { administração } \\
\text { Pessoal } \\
\text { Tipos de operações } \\
\text { Organização de } \\
\text { sistemas }\end{array}$ & $\begin{array}{c}\text { Gestão e } \\
\text { administração } \\
\text { Pessoal } \\
\text { Aspectos jurídicos } \\
\text { Organização e } \\
\text { planificação de } \\
\text { sistemas }\end{array}$ \\
\hline Tecnologia & $\begin{array}{c}\text { Aplicações } \\
\text { informáticas } \\
\text { Reprografia }\end{array}$ & $\begin{array}{c}\text { Aplicações } \\
\text { informáticas } \\
\text { Reprografia } \\
\text { Conservação e } \\
\text { restauração }\end{array}$ & $\begin{array}{c}\text { Aplicações } \\
\text { informáticas } \\
\text { Reprografia } \\
\text { Conservação e } \\
\text { restauração }\end{array}$ \\
\hline
\end{tabular}

Fonte: MARQUES (2011)

Conforme observamos no Quadro 5, na categoria "Métodos", onde são descritos "organização, interpretação, avaliação e utilização dos materiais", além do destaque dados aos processos de indexação e classificação, observa-se a inclusão de "serviços destinados aos usuários" na Documentação; "serviços de leitores" na Biblioteconomia; e "operações e serviços destinados aos usuários" na Arquivologia. Isso demonstra a possibilidade de um encontro entre essas disciplinas, visto que podem utilizar teorias e metodologias originárias de uma mesma fonte, nesse caso específico os "estudos de usuários", que tem suas raízes na Ciência da Informação, e que ao logo das últimas décadas tem mantido um diálogo constante com os três campos.

Apesar de todos os esforços e encontros realizados na década de 1980 em favor do movimento de harmonização, ele perde força na década de 1990.

Nos últimos anos, o que se busca atualmente é uma harmonização entre os currículos de Arquivologia no país, respeitando as especificidades regionais, um movimento que começa a ganhar força no Brasil em 2010, com a realização da I Reunião Brasileira de Pesquisa e Ensino em Arquivologia.

\subsubsection{Os estudos sobre o currículo no Brasil}

No Brasil as discussões sobre a formação do arquivista foram inauguradas em 1995 com a I Reunião Brasileira de Ensino em Arquivologia, que mais tarde se transformou nos Reparqs (Reunião Brasileira de Ensino e Pesquisa em Arquivologia), que já possuem três edições e continuam fomentando a discussão sobre a formação e as novas necessidades dentro da área.

Segundo Couture e Rosseau (1998, p. 120) "[...] não é tarefa única do arquivista unicamente adquirir, tratar e conservar os arquivos. O objetivo final dos arquivistas é tornar acessíveis e preparar a difusão das informações que eles mesmos recolhem". Essa 
discrepância entre a demanda do mercado de trabalho e o curso de formação nas universidades, segundo Souza (2011, p. 152), se justifica pelo fato de

[...] as relações das associações profissionais com os cursos superiores de arquivologia no Brasil serem bastante incipientes. As contribuições dos coletivos profissionais em relação à capacitação se concentram em cursos de curta duração e eventos promovidos com uma certa periodicidade.

O estreitamento desse diálogo entre instituições de ensino e coletivos profissionais podem contribuir muito para melhorias na formação de novos profissionais, conjuntamente com uma reestruturação dos currículos.

Em uma pesquisa de Souza (2011) que buscou avaliar a satisfação dos profissionais em relação às disciplinas ofertadas nos cursos, constatou-se que a maioria dos profissionais avaliou as disciplinas como não satisfatórias. Desde 1996, os cursos de arquivologia alteraram seus currículos para adequá-los à Lei de Diretrizes e Bases da Educação. A adaptação às diretrizes propostas pelo Ministério da Educação favoreceu a inserção de algumas disciplinas, assim como a supressão ou alteração de outras. Fato é que apesar de todas as alterações e estudos sobre o currículo, é necessário destacar a "[...] carga de responsabilidade social do arquivista" (SOUZA, 2011, p. 227).

A partir da década de 70 a arquivologia começa a emergir como disciplina e campo de atividades profissionais. Isto se expressa através de vários marcos como: a criação da Associação dos Arquivistas Brasileiros, realização dos primeiros congressos de arquivologia, regulamentação da profissão de arquivista, instituição do primeiro Sistema Nacional de Arquivos, etc (JARDIM; FONSECA, 1999). O ensino e a pesquisa brasileiros em arquivologia, conforme sugerido por pesquisas recentes, alinham-se, portanto, à tendência internacional após os anos 1990, deslocando-se da centralidade das instituições arquivísticas públicas para as universidades, "novo lócus" de produção e difusão do conhecimento arquivístico. (MARQUES; RONCAGLIO; RODRIGUES, 2011, p. 11). A arquivologia passa por um momento de auto definição e auto reconhecimento que trouxe a necessidade da organização de uma reunião nacional entre pesquisadores, professores e profissionais para uma discussão coletiva sobre a situação do ensino e da pesquisa brasileira na área.

No X Congresso Brasileiro de Arquivologia, realizado em 1994, o professor José Maria Jardim apresenta um trabalho fazendo um primeiro esboço sobre a situação dos cursos de arquivologia no Brasil, e levanta algumas questões importantes a serem discutidas. Como, por exemplo, "harmonização dos currículos". Neste estudo apresenta as disciplinas propostas pela Unesco para a harmonização entre arquivologia, ciência da informação e biblioteconomia, dentre elas destacamos a presença dos "estudos de usuários" como disciplina a ser "compartilhada" pela três áreas. Sugere ao final de sua apresentação a realização no ano seguinte da I Reunião Brasileira de Ensino em Arquivologia, com o intuito 
de aprofundar em diversos aspectos, principalmente no que diz respeito à formação profissional e mercado de trabalho.

Na I Reunião de Ensino em Arquivologia, em 1995 foi apresentado um quadro geral dos quatro cursos que haviam na época situados na UniRio, Univerisdade Federal de Santa Maria (UFSM), Universidade Federal Fluminense (UFF) e na Universidade de Brasília (UnB). Foram avaliados os objetivos dos cursos, duração da escolaridade, conteúdo, admissão, qualificação do corpo docente, recursos pedagógicos e repartição geográfica (JARDIM; FONSECA, 1999). Todas as comunicações realizadas no evento se transformaram na primeira publicação brasileira sobre a formação em arquivologia no país.

Foi apresentado um novo quadro de disciplinas básicas feito a partir do quadro de disciplinas do currículo mínimo proposto em 1974. A partir desse quadro foi elaborada uma nova "proposição de uma disposição hierárquica do conteúdo arquivístico", conforme o Quadro 8, com disciplinas fundamentais da arquivologia, disciplinas temáticas (que demonstra a relação interdisciplinar da área) e atividades dirigidas (que inclui o estágio obrigatório e a pesquisa em arquivologia).

Os Quadros 6 e 7 mostram a evolução desde o currículo mínimo proposto, até a nova proposta de Jardim e Fonseca. Em nenhum momento aparece de forma explícita a preocupação com a criação de disciplinas voltadas para os estudos e uso da informação arquivística. O que nota-se é uma preocupação não só com a conservação dos arquivos, mas também com a difusão da informação (COUTURE, 1992, p. 85).

Quadro 6

Hierarquia das matérias do curriculum minimum

\begin{tabular}{|c|c|c|c|}
\hline Matérias do curriculum minimum & Obrigatória & $\begin{array}{c}\text { Complementa } \\
\text { r }\end{array}$ & Opcional \\
\hline 1.Introdução ao estudo do direito & $\mathrm{X}$ & & \\
\hline 2.Introdução ao estudo da história & & $\mathrm{X}$ & \\
\hline 3.Noções de contabilidade & & & $\mathrm{X}$ \\
\hline 4. Noções de estatística & & & $\mathrm{X}$ \\
\hline 5.Arquivos I a IV & $\mathrm{X}$ & & \\
\hline 6.Documentação & $\mathrm{X}$ & & \\
\hline 7.Introdução à administração & $\mathrm{X}$ & & \\
\hline $\begin{array}{c}\text { 8.História administrativa, econômica e } \\
\text { social do país }\end{array}$ & $\mathrm{X}$ & & \\
\hline 9.Paleografia e diplomática & & $\mathrm{X}$ & \\
\hline 10.Introdução à comunicação & $\mathrm{X}$ & & $\mathrm{X}$ \\
\hline 11.Notariado & & $\mathrm{X}$ & \\
\hline 12.Língua estrangeira moderna & & & \\
\hline
\end{tabular}

Fonte: JARDIM; FONSECA, 1999 


\section{QUADRO 7}

Matérias do curriculum minimum atual e matérias do curriculum minimum

\section{Matérias do Curriculum Minimum}

$$
\text { Atual }
$$

1.Introdução ao estudo do direito

2.Introdução ao estudo da história

3.Noções de contabilidade

4. Noções de estatística

5.Arquivos I a IV

6.Documentação

7.Introdução à administração

8. História administrativa, econômica

e social do país

9.Paleografia e diplomática

10.Introdução à comunicação

$$
\text { 11.Notariado }
$$

12.Língua estrangeira moderna

Fonte: JARDIM; FONSECA, 1999

\author{
Matérias do Curriculum \\ Minimum Proposto

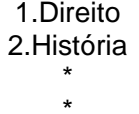

1.Direito

2.História

* \\ 3.Arquivística \\ 4.Biblioteconomia e Ciências \\ da Informação

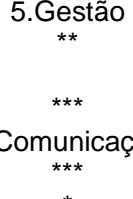

5.Gestão

*** \\ 6.Comunicação
}

7.Informática

\section{QUADRO 8}

Proposição de uma disposição hierárquica do conteúdo arquivístico

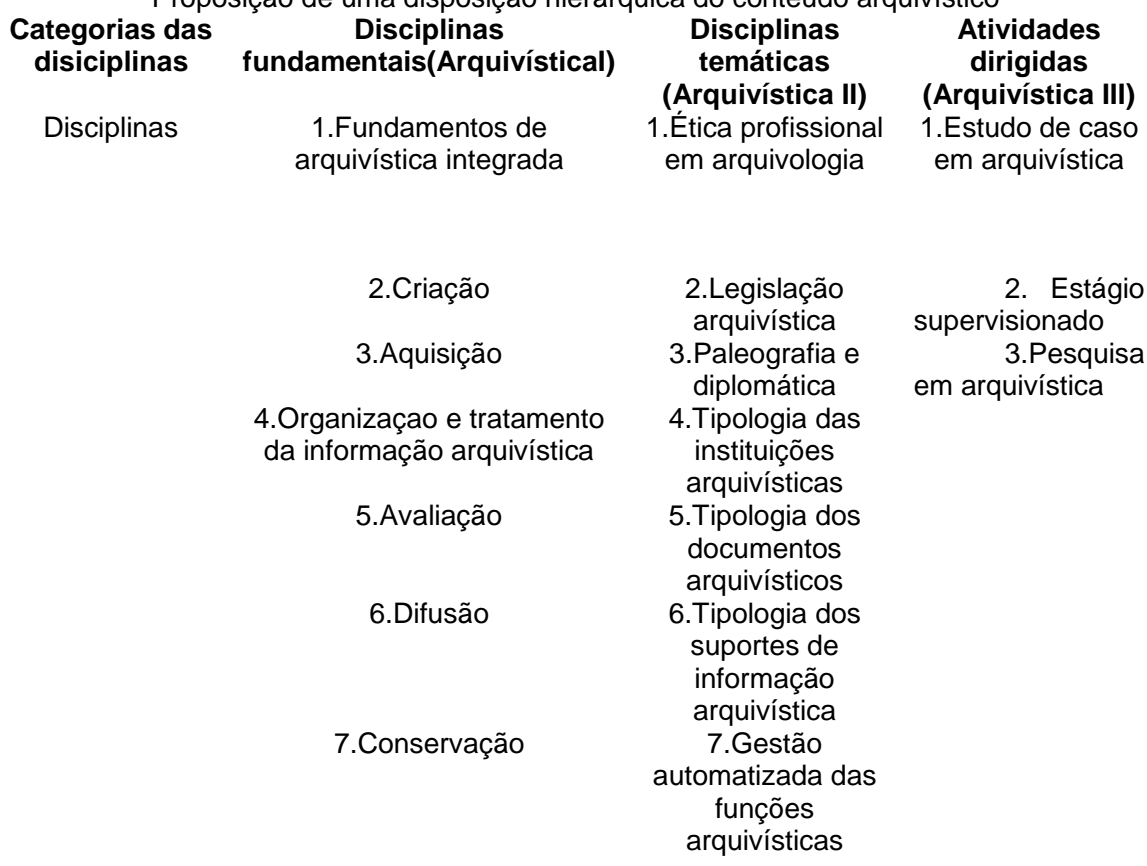


Fonte: JARDIM; FONSECA, 1999.

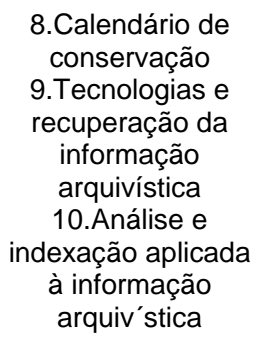

Em um cenário de profundas transformações, o arquivista deve ser formado sobre o paradigma do "Aprender a aprender". "Aprender a fazer" não é mais suficiente para o arquivista da era da informação. Como tal, não pode ser apenas um reprodutor de conhecimento, mas um produtor de conhecimento (JARDIM; FONSECA, 1999, p. 95).

A questão da interdisciplinaridade também é abordada no evento. De acordo com Bottino (1995),

[...] a arquivologia não esgota em si mesma todo o conhecimento necessário ao desempenho de suas funções. Pela própria natureza de seu campo de estudo, assume um caráter interdisciplinar onde o ensino deve estar aberto à interlocução com tantas outras áreas do saber e disciplinas (BOTTINO, 1995, p. 117).

Baseados em um quadro de Bellotto (1992), apontaram um referencial de disciplinas essenciais da arquivologia. Os Estudos de usuários aparecem em três "categorias diferentes", relacionada à história, estatística e ciências da informação, demonstrando as diversas formas de abordagens dessa temática.

A I Reunião Brasileira de Ensino e Pesquisa em Arquivologia vem dar continuidade à discussão iniciada na década de 1990 na Reunião Brasileira de Ensino em Arquivologia. A primeira REPARQ foi realizado na Universidade de Brasília em 2010, onde os coordenadores dos 14 cursos que haviam na época, foram convidados a apresentar o histórico de criação de cada curso, dificuldades enfrentadas, situação do corpo docente e discente e alguns aspectos dos currículos vigentes.

De acordo com Jardim (2011, p. 58), “[...] no marco da democratização do país, vários elementos sugerem alterações significativas no cenário arquivístico brasileiro, quando comparado com períodos anteriores". Essa mudanças referem-se principalmente a dimensão legal do acesso à informação, contemplado na Constituição de 1988, na Lei de Arquivos (Lei 8.159 , de 8 de janeiro de 1991) e outros instrumentos que vem de uma demanda social pela transparência da administração pública e o acesso à informação (BRASIL, 1988; 1991). Novamente percebe-se a necessidade da presença de disciplinas voltadas para os estudos de usuários na formação dos arquivistas. 
Sobre os estudos de usuários nos currículos de arquivologia, o evento apontou que na Universidade de Brasília onde o curso é vinculado `a Faculdade de Ciência da Informação, a disciplina "Estudo de usuários" é ofertada como disciplina optativa.

A Universidade Estadual de Londrina dividiu o currículo em seis eixos integradores, sendo que no segundo eixo integrador denominado "Gestão arquivística da informação" oferece a disciplina "Estudo de uso e usuário de arquivo". A nomenclatura da disciplina já demonstra uma preocupação em desenvolver estudos específicos sobre usuários de arquivos, o que não acontece em todas as universidades.

A Universidade Estadual Paulista apresentou dois grupos de disciplinas: as obrigatórias do núcleo geral e as obrigatórias do núcleo específico, e em nenhuma das categorias é ofertada disciplinas voltadas para o uso ou usuários de arquivos ou informação.

A Universidade Federal de Minas Gerais oferece a disciplina "Usuários da Informação", entre as disciplinas que compõem o "tronco comum" que é o conjunto de disciplinas também ofertadas aos cursos de biblioteconomia e museologia.

A Universidade Federal de Santa Maria apresentou apenas o quadro de disciplinas obrigatórias, onde não consta a presença de "Estudos de Usuários".

A Universidade Federal do Espírito Santo apresentou um quadro dividido em quatro "famílias". A disciplina "Estudo de usuários da informação" aparece na família "Fundamentos da Arquivística".

A Universidade Federal do Rio Grande apresentou a disciplina "Estudo de uso e usuários" no quadro de suas disciplinas obrigatórias.

A Universidade Federal Fluminense destaca a recomendação da Unesco para uma "harmonização na formação profissional, envolvendo biblioteconomia, arquivologia e ciência da informação e cita os "estudos de usuários" com uma área importante para concretização dessas recomendações. Mas no quadro de disciplinas de "formação comum" apresentados no evento ainda não constava nenhuma disciplina voltada para os estudos dos sujeitos.

A Universidade Federal da Paraíba, Universidade Estadual da Paraíba, Universidade Federal de Santa Catarina Universidade Federal do Amazonas e Universidade Federal do Rio Grande do Sul não apresentaram quadros gerais ou específicos das disciplinas ofertadas em seus currículos.

A Universidade Federal da Bahia e Universidade Federal do Rio de Janeiro apresentaram os quadros de disciplinas optativas e obrigatória, mas nenhum deles oferecia disciplinas voltadas para os estudos do sujeitos nos arquivos.

Nesta breve apresentação dos seus currículos e do fluxo curricular é possível notar uma falta de uniformidade nas nomenclaturas das disciplinas voltadas para os estudos de usuários. O que de fato não reflete um "problema" a ser solucionado no momento, visto que ainda não há um consenso dentro desses estudos a respeito da terminologia mais adequada. 
Além disso, também não há um consenso em qual grupo estas disciplinas devem estar presentes, se deve compor o quadro de disciplinas básicas obrigatórias do curso, ou se deve fazer parte do quadro de optativas, deixando o aluno livre para escolher se este tema deve compor ou não sua formação. Os organizadores deste evento citaram entre as recomendações finais "a necessidade de se harmonizarem minimamente os currículos de graduação, de modo a acompanharem os desafios e perspectivas para a arquivologia" (MARQUES; RONCAGLIO; RODRIGUES, 2011).

Em outro trabalho, Marques (2011) também faz uma análise dos currículos de arquivologia no Brasil, buscando "mapear a recepção, a utilização e os desdobramentos do currículo mínimo nos cursos de arquivologia, considerando a flexibilidade propiciada pela Lei de Diretrizes e Bases para a Educação Nacional (1996) quanto às reformas dos currículos, a partir de consultas de suas versões on-line" (MARQUES, 2011, p. 164). A autora fez uma análise qualitativa das denominações das disciplinas que compõem os currículos, buscando tecer algumas reflexões sobre a configuração científica da disciplina e suas relações extra disciplinares nesse processo. Essas reflexões produziram os seguintes resultados:

De acordo com a autora, a Unirio mantém em seu currículo, as disciplinas do currículo mínimo proposto em 1974, e ampliando o currículo em disciplinas voltadas para a organização dos acervos com características particulares (arquivos empresariais, especiais e contábeis). Há também a adaptação de disciplinas mais gerais para as demandas práticas e teóricas da arquivologia, como "Rede de sistemas de informação arquivística" e "Legislação arquivística", além de acompanhar as novas demandas tecnológicas com disciplinas voltadas para a gestão de documentos eletrônicos.

O curso de arquivologia da Universidade Federal de Santa Maria, assim como a UNIRIO, também mantém como base de construção de seu currículo, a proposta de currículo mínimo de 1974. Atualmente oferece disciplinas voltadas para as funções arquivísticas e também adapta disciplinas gerais para as especificidades da arquivologia (Banco de dados aplicados à arquivística, Estatística para a arquivologia, Ética e Legislação arquivística).

O currículo atual de arquivologia da Universidade Federal Fluminense, apresentava a teoria arquivística e os processos arquivísticos em disciplinas gerais de fundamentos e gestão de serviços.

O curso de arquivologia da Universidade de Brasília, segundo Marques (2011, p. 166), "[...] ainda tem um currículo preso á divisão dos arquivos por valores/freqüência de uso (corrente, intermediário e permanente), o qual não reflete a complexidade dinâmica dos processos e das atividades arquivísticas."

O curso da Universidade Estadual de Londrina, apresentava um currículo vigente desde 2005, contemplando disciplinas gerais voltadas para a gestão de documentos e disciplinas que foram adaptadas às especificidades da arquivologia (Elementos da lógica 
aplicados à arquivologia, gestão arquivística de documentos digitais, ética profissional aplicada à arquivologia, tópicos especiais em tecnologias aplicadas á arquivologia, fontes de informação no âmbito de arquivologia).

O curso da Universidade Federal da Bahia, de acordo com Marques, tem como destaque as disciplinas específicas de arquivologia oferecidas optativamente, possibilitando uma formação em que o profissional seja capaz de atuar em organização de acervos especiais e especializados.

A Universidade Federal do Rio Grande do Sul contempla em seu currículo de arquivologia de acordo com Marques (2011, p. 167) "[...] disciplinas que apreendem as funções arquivísticas nas suas peculiaridades e complexidades atuais". Destacando-se as disciplinas voltadas para o TCC, ética profissional e documentos eletrônicos.

O curso da Universidade Federal do Espírito Santo apresenta um currículo com foco "na gestão documental com abordagem tecnológica" (MARQUES, 2011, p. 167).

O curso de arquivologia da Universidade Estadual Paulista Júlio de Mesquita Filho (Unesp/ Marília), apresenta um currículo que conjuga as atividades arquivísticas às fases do arquivo, aliando questões atuais como a gestão eletrônica de documentos ás demandas do mundo do trabalho.

O currículo do curso da Universidade Estadual da Paraíba, focaliza a dinâmica das atividades arquivísticas destacam-se as disciplinas com preocupações com os documentos digitais, questões éticas e com a pesquisa.

A Universidade Federal da Paraíba apresenta um currículo as atividades arquivísticas em diálogo com disciplinas da informação, adapta disciplinas gerais ás especificidades da arquivologia. A autora destaca a disicplina "Marketing" em unidades de informação, que "parece abordar os desafios enfrentados pelos atuais arquivistas no mundo do trabalho" (MARQUES, 2011, p. 168).

O curso da Fundação Universidade do Rio Grande do Sul, apresenta em seu currículo disciplinas gerais adaptadas às especificidades da arquivologia, ética, produção de documentos eletrônicos e a organização de arquivos especiais e especializados. Novamente aparece a disciplina voltada para o marketing, que a exemplo da UFPB, não é específica da arquivologia, mas é ofertada na modalidade optativa.

O currículo do curso da Universidade Federal de Minas Gerais também contempla disciplinas gerais adaptadas às especificidades dos arquivos, mas diante de uma perspectiva de um tronco comum de ensino, compartilha um grande número de disciplinas com outros dois cursos da escola (biblioteconomia e museologia).

$\mathrm{Na}$ Universidade Federal do Amazonas apresenta disciplinas voltadas para as atividades arquivísticas, com ênfase nas práticas profissionais(quatro disciplinas de estágio). 
Destaca-se aqui a presença de disciplinas voltadas para o estudo de usuários de arquivos e de gestão arquivística de documentos.

A Universidade Federal de Santa Catarina, assim como a maioria das universidades, contempla em seu currículo de arquivologia disciplinas adaptadas às demandas dos arquivos, disciplinas sobre ética, arquivo digital, arquivometria e TCC.

A Universidade Federal do Pará, não teve seu currículo analisado neste estudo, pois na época, não disponibilizava tal informação.

Em linhas gerais Marques (2011, p. 169), concluiu que "[...] mesmo considerando somente as denominações das disciplinas, permite-nos observar que, quanto ao modelo de currículo mínimo proposto em 1974, todos os cursos se apropriaram das disciplinas relativas a Arquivo I-IV, numa perspectiva voltada para a sua distribuição conforme os valores/ freqüência de uso dos arquivos (UnB, UFBA), ou de acordo com as funções arquivísticas(Unirio UFSM, UEL, UFRGS, Ufes, FURG, Ufam E UFSC) ou com a combinação das duas perspectivas (UFF, Unesp, UEPB, UFPB e UFMG).

Além dessas temáticas, destacam-se a Universidade Estadual de Londrina (UEL), a Universidade Estadual da Paraíba (UEPB), e a Universidade Federal do Amazonas (UFAM), que contemplavam na época deste estudo em seus currículos a disciplina de "usuários de arquivos". Sendo que a UEPB adaptou a disciplina estudos de usuários para a especificidade da arquivologia, sendo denominada "Usos e usuários da informação arquivística".

Vale lembrar que a maioria das universidades ainda passa por revisão e reconstrução de seus currículos, e o que se espera de acordo com as recomendações do I REPARQ é uma harmonização entre os currículos dos cursos oferecidos no país, não esquecendo, é claro, das necessidades específicas de cada região, que demandam diferentes características na formação do profissional.

Em 2012, foi realizado um novo estudo sobre currículos por Negreiros, Arreguy e Silva, apresentado no $\mathrm{V}$ Congresso Nacional de Arquivologia (CNA). Este trabalho tinha como objetivo

[...] apresentar uma metodologia para análise, avaliação e reestruturação curricular de cursos de Arquivologia, como forma de facilitar os processos de reestruturação das grades de disciplinas, sistematizar as discussões em reuniões com essa temática e acompanhar as preocupações constantes com as questões de ensino e pesquisa na área (NEGREIROS; ARREGUY; SILVA, 2012, p. 3).

Este estudo apresenta um panorama dos currículos de Arquivologia brasileiros, baseado nos trabalhos apresentados na I Reunião Brasileira de Ensino e Pesquisa em Arquivologia, descrevendo tendências no que se refere à formação de discentes na área; discute os processos de reestruturação curricular, apresentando, mais de perto, o caso do curso de Arquivologia da Escola de Ciência da Informação da Universidade Federal de Minas 
Gerais (ECI/UFMG); expõe a metodologia utilizada, tanto no que se refere a sua sustentação teórica, quanto a seus procedimentos metodológicos; realiza reflexões sobre a metodologia criada, com o intuito de indicar qualidades/melhorias e outros estudos possíveis a partir dessa iniciativa.

Os autores utilizaram um quadro de proposições de disciplinas de Couture, Martineau e Ducharme de 1999, conforme demostrado no Quadro 8, para direcionar o que seria as disciplinas que compõem o conhecimento arquivístico. Utilizaram também uma segunda tabela, conforme Quadro 9, com a "tipologia dos campos de pesquisa em arquivística" com temas que abordam as especificidades da área. Usaram como referência um diagrama de Silva e Ribeiro (1999) que traça um "diagrama do campo científico da arquivística" para que pudessem compreender melhor a composição do campo e trabalhar na reestruturação curricular de forma a atender as novas demandas sociais.

\section{QUADRO 9}

Proposições de disciplinas

\begin{tabular}{|c|c|c|c|}
\hline $\begin{array}{c}\text { Arquivística } \\
\text { pura }\end{array}$ & $\begin{array}{c}\text { História sob } \\
\text { medida }\end{array}$ & $\begin{array}{c}\text { Ciências da } \\
\text { Informação }\end{array}$ & Ciências conexas \\
\hline $\begin{array}{c}\text { Arquivística } \\
\text { fundamental }\end{array}$ & $\begin{array}{c}\text { História dos } \\
\text { arquivos }\end{array}$ & $\begin{array}{c}\text { Fundamentos } \\
\text { das ciências da } \\
\text { informação }\end{array}$ & $\begin{array}{c}\text { Organização e gestão de } \\
\text { um serviço de arquivos }\end{array}$ \\
\hline $\begin{array}{c}\text { Gestão de } \\
\text { arquivos }\end{array}$ & $\begin{array}{c}\text { História da gestção } \\
\text { dos documentos e } \\
\text { dos arquivos }\end{array}$ & $\begin{array}{c}\text { Acesso, } \\
\text { recuperação e } \\
\text { difusão da } \\
\text { informação }\end{array}$ & $\begin{array}{c}\text { Análise das } \\
\text { necessidades(diagnóstico) }\end{array}$ \\
\hline $\begin{array}{c}\text { Gestão de } \\
\text { documentos }\end{array}$ & $\begin{array}{c}\text { História da } \\
\text { profissão de } \\
\text { arquivista }\end{array}$ & $\begin{array}{c}\text { Referência e } \\
\text { estudo de } \\
\text { usuários }\end{array}$ & Contabilidade \\
\hline $\begin{array}{c}\text { Funções } \\
\text { arquivísticas }\end{array}$ & $\begin{array}{c}\text { História das } \\
\text { instituições } \\
\text { arquivísticas }\end{array}$ & $\begin{array}{c}\text { Preservação e } \\
\text { conservação }\end{array}$ & Automatização da gestão \\
\hline $\begin{array}{c}\text { Diplomática e } \\
\text { arquivística } \\
\text { descritiva }\end{array}$ & $\begin{array}{c}\text { História da } \\
\text { administração }\end{array}$ & $\begin{array}{c}\text { Análise e design } \\
\text { de sistemas de } \\
\text { informação }\end{array}$ & $\begin{array}{c}\text { Sociologia da } \\
\text { administração }\end{array}$ \\
\hline $\begin{array}{c}\text { Políticas e } \\
\text { gestão de } \\
\text { programas } \\
\text { arquivísticos }\end{array}$ & $\begin{array}{c}\text { História do } \\
\text { contexto social }\end{array}$ & $\begin{array}{c}\text { Bases de dados } \\
\text { Línguas vivas }\end{array}$ & \\
\hline
\end{tabular}




\begin{tabular}{|c|c|c|c|}
\hline $\begin{array}{c}\text { Legislação e } \\
\text { questões } \\
\text { jurídicas }\end{array}$ & História intelectual & $\begin{array}{c}\text { Utilização de } \\
\text { novas } \\
\text { tecnologias }\end{array}$ & \\
\hline $\begin{array}{c}\text { Suportes } \\
\text { especiais }\end{array}$ & $\begin{array}{c}\text { Ciências e } \\
\text { tecnologias de } \\
\text { interpretação } \\
\text { histórica }\end{array}$ & $\begin{array}{c}\text { Gestão dos } \\
\text { documentos } \\
\text { eletrônicos }\end{array}$ & \\
\hline $\begin{array}{c}\text { Documentação } \\
\text { oral }\end{array}$ & Geografia histórica & & \\
\hline $\begin{array}{c}\text { Iniciação á } \\
\text { pesquisa } \\
\text { arquivística }\end{array}$ & $\begin{array}{c}\text { Métodos de } \\
\text { pesquisa histórica }\end{array}$ & & \\
\hline
\end{tabular}

Fonte:COUTURE; MARTINEAU; DUCHARME, 1999, p. 74.

\section{QUADRO 10}

Tipologia dos campos de pesquisa em arquivística

\begin{tabular}{|c|c|}
\hline Campos de pesquisa & Descrição do conteúdo \\
\hline Objeto e finalidade arquivística & $\begin{array}{c}\text { Arquivos enquanto objetos de } \\
\text { intervenção } \\
\text { (informação/documento/arquivos) ; } \\
\text { Finalidade: conservação, acesso, eficácia } \\
\text { administrativa e outras ; } \\
\text { Utilidade de arquivos. }\end{array}$ \\
\hline Arquivos e sociedade & $\begin{array}{l}\text { Papel social e lugar da arquivística na } \\
\text { sociedade ; } \\
\text { Aquivística, enquanto disciplina ; } \\
\text { Arquivística, enquanto profissão. }\end{array}$ \\
\hline História dos arquivos e da arquivística & $\begin{array}{c}\text { História dos arquivos } \\
\text { Desenvolvimento dos princípios e das } \\
\text { bases da } \\
\text { Arquivística }\end{array}$ \\
\hline Funções arquivísticas & $\begin{array}{l}\text { Produção, avaliação, aquisição, } \\
\text { classificação, } \\
\text { descrição, preservação e difusão }\end{array}$ \\
\hline $\begin{array}{c}\text { Gestão dos programas e dos serviços } \\
\text { de arquivos }\end{array}$ & $\begin{array}{l}\text { Teoria e prática das organizações } \\
\text { Planificação e avaliação dos programas } \\
\text { Gestão, marketing e relações públicas. }\end{array}$ \\
\hline Tecnologias & $\begin{array}{l}\text { Informática aplicada aos arquivos ; } \\
\text { Sistemas de informação, } \\
\text { telecomunicação e redes. }\end{array}$ \\
\hline Suportes e tipos de arquivos & $\begin{array}{c}\text { Arquivos audiovisuais, eletrônicos, } \\
\text { iconográficos e } \\
\text { textuais; } \\
\text { Microformas e outros suportes ou tipos } \\
\text { de arquivos }\end{array}$ \\
\hline
\end{tabular}




\begin{tabular}{|c|c|}
\hline Meio profissional dos arquivos & $\begin{array}{c}\text { Instituições governamentais ; } \\
\text { Instituiços de ensino e pesquisa ; } \\
\text { Instituições religiosas ; } \\
\text { Outras instituições . }\end{array}$ \\
\hline $\begin{array}{c}\text { Problemas particulares relativos aos } \\
\text { arquivos }\end{array}$ & $\begin{array}{c}\text { Ética ; } \\
\text { Acesso à informação e proteção da vida } \\
\text { privada; } \\
\text { Outros. }\end{array}$ \\
\hline
\end{tabular}

Fonte:COUTURE; MARTINEAU; DUCHARME, 1999, p. 76.

A partir das referências baseadas em estudos anteriores e na avaliação de currículos de arquivologia de outras universidades brasileiras, criaram um quadro com 11 categorias com temáticas específicas do campo e doze categorias com as "relações interdisciplinares previstas." A partir de uma primeira avaliação foi criado um gráfico com as temáticas que naquela época compunham o currículo de arquivologia da Universidade Federal de Minas (UFMG), totalizando 23 temáticas diferentes. O tema "Usuários" aparece entre essas temáticas, mas ainda de uma forma bastante tímida. O Quadro 10 apresenta as treze categorias de relações interdisciplinares previstas criadas pelos autores.

\section{QUADRO 11}

Relações interdisciplinares previstas

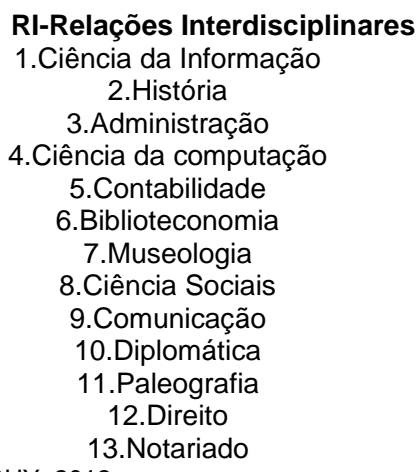

Fonte:NEGREIROS; SILVA; ARREGUY, 2012.

Em outra etapa que envolve a opinião dos professores, foi avaliado a "adequação das disciplinas ao período que são ofertadas". Nesta avaliação a disciplina "usuários da informação" foi classificada como uma disciplina que "[...] necessita ser realocadas na grade curricular" por 40\% dos docentes (NEGREIROS; ARREGUY; SILVA, 2012, p.28).

Percebe-se neste estudo, no caso dos estudos de usuários, que a disciplina "usuários da informação" ainda é motivo de muita divergência e estudos sobre sua adequação no curso de arquivologia. A proposta final dos autores foi realizar esta análise nos outros cursos de 
arquivologia do país. Essas análises foram realizadas pelos mesmos autores e apresentadas na III Reunião Brasileira de Ensino e Pesquisa em Arquivologia.

Nesse novo trabalho Negreiros, Silva e Arreguy criaram 23 categorias de classificação de disciplinas interdisciplinares para mapear os currículos dos 16 cursos de arquivologia do país, conforme o Quadro 12:

\section{QUADRO 12}

Categorias de classificação

\begin{tabular}{|c|c|}
\hline \multicolumn{2}{|c|}{ Relações interdisciplinares } \\
\hline RI1.Ciência da Informação & RI13.Notariado \\
\hline RI2.História & RI14.Letras e línguas \\
\hline RI3.Administração & RI15.Estatística \\
\hline RI4.Ciência da computação & RI17.Antropologia \\
\hline RI5.Contabilidade & RI18.Matemática \\
\hline RI6.Biblioteconomia & RI19.Economia \\
\hline RI7.Museologia & RI20.Psicologia \\
\hline RI8.Ciência Sociais & RI21.Ciências políticas \\
\hline RI9.Comunicação & RI22.Educação \\
\hline RI10.Diplomática & RI23.Temas diversos/tópicos-relações \\
\hline RI11.Paleografia & interdisciplinares \\
\hline RI12.Direito & \\
\hline \multicolumn{2}{|c|}{ Fonte: NEGREIROS; SILVA; ARREGUY, 2012 }
\end{tabular}

Fonte: NEGREIROS; SILVA; ARREGUY, 2012.

Foi criada uma categoria exclusiva para "Usuários", dentro das disciplinas específicas, como demostrado no Quadro 12, que envolve estudos de usos e usuários de arquivos; tipos e categorias de usuários de arquivos; serviços destinados aos usuários de arquivos; demandas e necessidades dos usuários de arquivos; difusão e acesso (NEGREIROS; SILVA; ARREGUY, 2012).

\section{QUADRO 13}

Disciplinas Específicas

\begin{tabular}{|c|}
\hline Específicas \\
\hline 1.Fundamentos da arquivologia \\
\hline 2.O Profissional da arquivologia \\
\hline 3.Gestão de documentos \\
\hline 4.Gestão de documentos eletrônicos e digitais \\
\hline 5.Arquivo permanente \\
\hline 6.Preservação/Conservação/Restauração \\
\hline 7.Planejamento e projetos arquivísticos \\
\hline 8.Usuários \\
\hline 9.Políticas e legislação arquivística \\
\hline 10.Métodos e técnicas de pesquisa em arquivologia \\
\hline 11.Temas diversos/Tópicos em arquivologia/Estágio \\
\hline Fonte: NEGREIRO; SILVA; ARREGUY, 2013.
\end{tabular}

Fonte: NEGREIRO; SILVA; ARREGUY, 2013. 
Além da avaliação dos autores, os resultados tiveram também a avaliação dos coordenadores dos cursos. Utilizou-se como pressuposto para análise da frequência das disciplinas: a) primeira premissa: nas disciplinas obrigatórias os conteúdos específicos deveriam aparecer com mais frequência que os conteúdos interdisciplinares; e b) segunda premissa: nas disciplinas optativas, os conteúdos específicos e interdisciplinares devem aparecer de forma equilibrada.

Seguindo a primeira premissa as disciplinas que tratam sobre estudos de usuários, que estão inseridas na categoria de disciplinas específicas deveriam aparecer com maior frequência. Mas não é isso que acontece. A categoria "Usuários" não aparece na Universidade Federal de Santa Maria(UFSM) e na Universidade Federal Fluminense (UFF). Mas, mesmo assim, os autores consideraram que a temática aparece com uma frequência "média" nos currículos dos cursos, sendo que as maiores frequências aparecem na Universidade Federal do Rio Grande (FURG) e na Universidade Federal do Espírito Santo (UFES). Os resultados demonstram ainda uma discrepância muito grande entre os cursos com a menor e maior frequência de disciplinas com a temática de "Usuários".

$\mathrm{O}$ que percebe-se em todos os estudos avaliados, em um espaço de quase 20 anos desde o estudo inaugural sobre formação do arquivista de José Maria Jardim e Maria Odila da Fonseca, é uma notória "evolução" da discussão sobre o tema e na própria reestruturação dos currículos. Além das discussões entre professores e pesquisadores, a flexibilidade dos currículos permitida pela Lei de Diretrizes e bases da Educação de 1996, foi fundamental nesse processo. O currículo mínimo não existe mais, abolindo a "grade curricular" que enrijecia a formação profissional. O que existe hoje é uma "matriz curricular" sujeita a transformações para acompanhar as exigências da sociedade. "[...] um currículo reflete uma época. Ele sofre influências do estágio de maturidade em que se encontra a área do conhecimento, da atuação dos profissionais no mercado de trabalho, da visão política e ideológica da instituição, dos recursos humanos e financeiros" (CESARINO; VIANNA, 1990, p. 37).

As disciplinas relacionadas aos estudos de usuários e uso da informação arquivística ainda estão em estado incipiente nos currículos dos cursos, se mostrando em alguns casos presas aos métodos de estudos de usuários em bibliotecas, não atendendo as necessidades do arquivista, visto que, o comportamento de busca de informação do usuário de arquivo é bem diferente do usuário de uma biblioteca. A dificuldade de estruturação de uma disciplina específica para estudos de usuários em arquivologia justifica-se também pelos diferentes tipos de usuários de um arquivo. Faltam ainda estudos de caso sobre a temática na área. Mas, o que fica nítido é a vontade e a necessidade dos pesquisadores em colocar a temática dentro das disciplinas específicas da arquivologia. Anteriormente estes estudos eram colocados em um lugar mais distante, estando intimamente relacionada à ciência da informação. 


\subsection{O ACESSO AOS ARQUIVOS}

A pesquisadora Menne-Haritz (2001) coloca como ponto crucial para a mudança de um paradigma custodial para o pós-custodial o fim das divisões entre blocos socialistas e comunistas no mundo. Aqui no Brasil podemos tomar como referência os avanços em relação ao acesso à informação obtidos após o regime militar, que será também abordado ao longo desse tópico. A abertura dos arquivos só foi possível após a abertura política de muitos países, visto que grande parte dos documentos eram e em boa parte ainda são de responsabilidade da administração pública, ficando a cargo do governo criar suas políticas de acesso.

Com a instauração da Comissão da Verdade aqui no Brasil, tem se falado muito sobre a questão da memória, da preservação do passado para a construção de um futuro mais próspero, evitando cometer os mesmos erros, especialmente aqueles que ferem a cidadania e a democracia. De acordo com Menne-Haritz (2001), a memória não está em um suporte de informação, em livros, documentos ou em meios digitais, mas está no conteúdo do documento. E neste sentido o arquivo não funciona como uma "fábrica de memória", visto que a história é uma construção coletiva, e só existe memória a partir desta história vivida e contada. Mas os arquivos "criam memória", pois funcionam como uma prevenção para a amnésia. Ainda segundo a autora, o arquivo existe para responder as questões de uma sociedade, de seus conflitos sobre sua própria história. Portanto, as velhas práticas arquivísticas devem se revestir das necessidades atuais, e para que isso aconteça a mudança na formação e na compreensão dos profissionais se torna essencial.

A partir dessas mudanças estamos diante de um novo paradigma, que Menne-Haritz chama de "paradigma do acesso", que surge "transformando o lugar das diferenças, entre passado e futuro dentro do pensamento arquivístico" (MENNE-HARITZ, 2001, p.60, tradução nossa).

Jardim (1995) aponta que recorre-se atualmente, com muita frequência, à temática da memória, expressão de interesses e paixões e objeto de um campo interdisciplinar. Diversos termos tendem a ser associados à memória: resgate, preservação, conservação, registro, seleção etc.

Le Goff (1984) sugere algumas teses a respeito da memória:

- sua crucialidade, expressa em noções que se remetem mutuamente: tempo e espaço, suporte e sentido, memória individual e coletiva, tradição e projeto, acaso e intenção, esquecimento e lembrança etc.; 
- as diferenças de natureza entre sociedades com escrita ou não, influindo na construção social damemória;

- as diferentes memórias ao longo da história;

- a memória como fonte de identidade individual e de uma dada sociedade;

- a memória como objeto de luta das forças sociais pelo poder.

Segundo Arantes (1984, p.3):

No caso brasileiro os aspectos técnicos têm predominado nas discussões sobre o patrimônio em detrimento do seu sentido político mais amplo. Como resultado, a maior parte dos bens preservados expressariam o nicho lusobrasileiro, agrário e escravista da nossa cultura, pouco acessível a uma população que tenderia à indiferença a este patrimônio 'de um país distante e alheio'. Neste sentido, Santos (1988, p.250) questiona as concepções de patrimônio cultural dominantes no Brasil e suas vinculações ao elogio de poder em diversos níveis, levando à permanente valorização de um padrão de cultura que, orientado pelo iluminismo, mantém-nos distantes de uma apreensão plural e democrática da realidade social que nos envolve.

Isso nos leva a pensar com mais cuidado sobre as raízes dos problemas relacionados ao acesso aos arquivos em nosso país. É um problema histórico, inserido dentro de um contexto complexo que tem sua origem bem antes do período de ditadura brasileira. Suas causas estão mais gravemente ligadas à questões culturais de dominação implantadas desde a colonização do nosso país, onde a cultura branca europeia influenciou e deixou resquícios de uma desvalorização do que é tido como popular. Essas ações prejudicaram ainda trazem um reflexo negativo no processo de democratização cultural e informacional no país.

Jardim (1995) ainda destaca o discurso de Favier na abertura do XII Congresso Internacional de Arquivos (MONTREAL, 1992) onde é enfático a respeito da responsabilidade do profissional na preservação da memória para a construção de um futuro: "Somos arquivistas, não somos homens do passado. Nós temos a responsabilidade da memória comum dos homens e uma responsabilidade na construção do futuro. Estamos a serviço da vida, somos responsáveis por uma memória ativa que é, antes de tudo, um instrumento de trabalho para as sociedades humanas. A memória é o fundamento dos direitos dos cidadãos"(FAVIER apud JARDIM, 1995, p. 5).

Sobre a constituição dos arquivos e seu atendimento e organização ainda precários, Jardim (1995) relata que os arquivos públicos latino-americanos institucionalizaram-se como resultado de um processo de independência e formação dos Estados modernos na região. Sob os projetos emergentes de nação, estas instituições foram consideradas arquivos históricos e, portanto, repositórios de uma memória tida como forjadora da identidade nacional. Isto implicou o desenvolvimento de arquivos públicos e serviços arquivísticos "periferizados" na administração pública, incapazes de fornecer informações suficientes para a pesquisa científica e tecnológica e à sociedade como um todo. 
As investigações, interpretações, e combinações de dados dentro do arquivo, produzem informação em forma de novo conhecimento procurando responder as questões do usuário.

Então, nos dias atuais, a custódia não faz sentido se não houver o acesso. Por isso a importância de se abrir uma agenda de investigação sobre a inserção dos estudos de usuários nesse processo, para que se complete o ciclo. Vale destacar ainda, que ações de educação de usuários, mediação arquivística, que será tratado neste trabalho, vai além de "orientar" os usuários, na verdade é a razão de existência dos arquivos. Veremos então como a questão do acesso evoluiu com o decorrer do tempo.

"O objetivo é o uso". Precisamos estar sempre atentos a esse fato. Identificação, aquisição, descrição e todo o resto são simplesmente os meios que usamos para atingir essa meta. Eles são ferramentas. Precisamos empregar todas essas ferramentas habilmente, mas se, após avaliar meticulosamente, arranjar, descrever e conservar nossos documentos, ninguém vem para usá-los, então nós desperdiçamos nosso tempo (ERICSON apud COUTURE, 2003, p. 379).

De acordo com Costa (2011, p. 22), "[...] o acesso é elemento indispensável para se compreender a relação entre instituição arquivística e usuário". Taylor (1984, p. 23) considera que o mais importante serviço de uma instituição arquivística pode proporcionar é a disponibilização dos materiais demandados pelo usuário.

Os arquivos nasceram com a força de uma representação da herança cultural de uma nação (os arquivos nacionais) e com a promessa de preservação dos registros dos acontecimentos "do presente e do futuro", evitando assim, que se somassem à coleção de ruínas do passado. "O respeito creditado aos arquivos nacionais advém da função de guardiã de documentos produzidos pelo estado, por conseguinte, responsável pela proteção dos direitos e interesses do povo neles registrados" (COSTA, 2011, p. 23).

A lei de 7 Messidor, editado no segundo ano da Revolução Francesa, garantiu a todo e qualquer cidadão o acesso aos documentos públicos. Mas, Silva et al. (1999), ao mesmo tempo em que conferem à Revolução Francesa a autoria da abertura dos arquivos ao cidadão, afirmam que a lei não foi seguida de imediato pela prática. Segundo Souza et al. (1999),

[...] é, com efeito, uma ordem nova que nasce para os arquivos, se bem que, como vimos, não isenta de contradições e de aplicação não imediata, pois só em meados do século XIX surgem, de fato, salas para consulta nos arquivos, requisito de certo modo imposto pelas necessidades da ciência histórica. (SOUZA et al., 1999, p. 102).

Como percebe-se os historiadores e os processos de investigação histórica "pressionaram" a abertura dos arquivos para consulta à suas coleções. A esse respeito, Duchein (1983) diz que: 
[...] as leis e os regulamentos foram concebidos exclusivamente para facilitar a investigação de caráter histórico e erudito baseado nos documentos do passado, mas não para permitir que o cidadão comum conhecesse os procedimentos governamentais e administrativos recentes e atuais. (DUCHEIN, 1983, p. 5, tradução nossa) ${ }^{2}$

O interesse cultural foi o baluarte dos historiadores para impor a abertura dos arquivos. A partir de 1830, a École des Chartes abriu cursos de paleografia e diplomática promovendo o que Silva et al. (1999, p. 108) denominaram "[...] movimento de renovação da historiografia [...] e graças aos qual se assiste a uma forte valorização das fontes históricas e da pesquisa nos arquivos".

Segundo Costa (2011),

[...] até a primeira metade do século XX não se observam mudanças substantiva com relação à abertura dos arquivos ao público. $O$ direito à informação só foi cogitado em 1948, com a publicação da Declaração Universal dos Direitos do Homem pela Assembleia Geral das Nações Unidas. (COSTA, 2011, p. 24).

Conforme o artigo 19 da Declaração Universal do Direitos Humanos, de 10 de dezembro de 1948 "Toda pessoa tem direito à liberdade de opinião e expressão; este direito inclui a liberdade de, sem interferência, ter opiniões e de procurar, receber e transmitir informações e ideias por quaisquer meios e independentemente de fronteiras" (DECLARAÇÃO..., 1948).

A lei, então tira o privilégio de consulta dado apenas aos historiadores e garante a todos os povos conhecer o conteúdo dos documentos produzidos e preservados pelo Estado. Especialmente a partir dos anos 1960, as instituições arquivísticas passaram por um novo desafio. O grande público começa a manifestar um crescente interesse por documentos antigos existentes nesses repositórios. À medida que o cidadão começa a conhecer e exercer os seus direitos, aumenta no cenário mundial a propagação e o consumo da informação. Duchein (1983, p. 9), conceituou esse novo "personagem" da seguinte maneira; por "grande público", nós entendemos que são todos aqueles que não são historiadores profissionais ou amadores, nem estudantes, nem interessados profissionalmente pelos arquivos: é como são chamados, numa expressão familiar e simpática, "o homem da rua".

A Declaração dos Direitos do Homem representou a formalização legal do acesso à informação, porém, ainda ficou a cargo de cada nação regulamentar como se dará o acesso. O acesso passa a ser então um "acordo" estabelecido entre o Estado e o povo.

Mas, de modo geral, de acordo com Costa (2011, p. 24), quando se fala de acesso a informações de arquivo, o direito do cidadão encontra limitações em todos os países, uns

${ }^{2}$ DUCHEIN, 1983, p. 5. Original na língua Inglesa. 
mais, outros menos. Segundo Duchein (1983, p. 7), as restrições mais comuns decorrem de obrigações do Estado, tais como:

- Resguardar o direito dos cidadãos a respeito de sua vida privada;

- Proteger a segurança dos estados e suas relações multilaterais e bilaterais;

- Garantir ordem pública e a segurança dos cidadãos e, em particular, de perseguir os culpados por crimes e delitos e impedir-Ihes que prejudiquem a sociedade;

- Proteger a propriedade intelectual;

- Proteger o segredo industrial e comercial;

- Em se tratando de arquivos privados, garantir o direito de livre uso dos bens privados por seus proprietários.

Diferentemente de registros documentais encontrados em bibliotecas e museus, os documentos de arquivo produzido por autoridade pública no exercício de suas funções deve ser administrado pelo Estado. Compete então ao Estado interferir na administração desses documentos sob o argumento da proteção a intimidade, ao bem-estar do cidadão, da defesa nacional e da propriedade intelectual. Os arquivos públicos são gerados primeiro por necessidades administrativas e de governo e não para servir de fonte de informação à terceiros. Então, de acordo com este raciocínio, a função de disponibilizar informação para a população seria uma função secundária dos arquivos (COSTA, 2011, p. 24)

Antes da Segunda Guerra Mundial, a maioria dos países adotava prazos de manutenção de sigilo variando entre cinquenta anos, sessenta ou mais. Após a Segunda Guerra os arquivos se viram forçados a avaliar suas restrições de acesso. Alguns elementos impulsionaram esse processo de abertura dos arquivos, de acordo com Duchein (1983, p. 5):

- A mudança temática dos estudos históricos, cada vez mais interessados em eventos ocorridos em épocas recentes;

- O desenvolvimento dos métodos da pesquisa quantitativa (história demográfica, história econômica, etc.), exigindo a consulta de uma massa de documentos para extração de dados numéricos mensuráveis;

- O crescente interesse em aspectos econômicos e sociais da história, despertando a consulta a arquivos de empresas, associações, sindicatos, até então pouco conhecidos e pouco procurados;

- A ampliação das relações internacionais e intercontinentais, influenciando os deslocamentos de pesquisadores de um país a outro e cobrando dos arquivos adaptações para atender o pesquisador estrangeiro;

- A emergência progressiva, especialmente a partir dos anos 1960, da noção de direito à informação, como um direito democrático de todo cidadão; 
- A expansão dos estudos históricos, em contrapartida, trazendo o risco de deterioração dos documentos nos arquivos, devido ao grande número de manipulação;

- Enfim, os progressos tecnológicos, colocando possibilidades inéditas de preservação dos documentos e acesso aos arquivos.

Quando o Arquivo Nacional foi criado no Brasil em 1838, a lei não previa demarcar uma consciência de preservação do patrimônio nacional. A proteção dos documentos históricos só veio a ser mencionada nas Cartas Constitucionais de 1934 e 1937. A defesa dos direitos dos cidadãos e esclarecimentos junto à administração pública, só apareceu mais tarde, nas leis de 1946 e de 1967. Mas, o "[...] cidadão brasileiro teve que aguardar até o final do século XX para exercer seus direitos" (COSTA, 2011, p. 26). Em 1988 foi promulgada a Constituição que começa a garantir, ao menos em lei, a cidadania do povo brasileiro, com a seguinte redação:

De acordo com o artigo. 5ำ da Constituição Federal Brasileira, de 1988, dos direitos e garantias fundamentais são invioláveis a intimidade, a vida privada, a honra e a imagem das pessoas, assegurando o direito à indenização pelo dano material ou moral decorrente de sua violação. No inciso XXXIII deste artigo prevê que todos têm direito a receber dos órgãos públicos informações de seu interesse particular, ou de interesse coletivo, ou geral, que serão prestados no prazo da lei, sob pena de responsabilidade, ressalvadas aquelas cujo sigilo sejam imprescindíveis à segurança da sociedade e do Estado (BRASIL, 1988).

Com base na Constituição de 1988, Bastos e Araújo (1989), criaram um quadro com o objetivo de demonstrar as garantias reais de acesso possíveis de acordo com a legislação brasileira. O Quadro 13 mostra a realidade jurídica documental brasileira, dando esclarecimentos sobre o que de fato o cidadão pode acessar.

\section{QUADRO 14}

Realidade jurídica documental, com base na Constituição da República

\begin{tabular}{|c|c|c|}
\hline Tipo & Característica & Acesso \\
\hline $\begin{array}{c}\text { Arquivo de documentos } \\
\text { governamentais }\end{array}$ & $\begin{array}{c}\text { Documentos produzidos } \\
\text { por autoridade pública }\end{array}$ & $\begin{array}{c}\text { Consulta franqueada nos } \\
\text { termos da lei }\end{array}$ \\
\hline $\begin{array}{c}\text { Arquivo de documentos } \\
\text { patrimoniais(de valor } \\
\text { histórico) }\end{array}$ & $\begin{array}{c}\text { Documentos públicos de } \\
\text { importância histórica } \\
\text { produzidos por autoridade } \\
\text { pública }\end{array}$ & $\begin{array}{c}\text { Aceso } \\
\text { pleno(constitucional) }\end{array}$ \\
\hline $\begin{array}{c}\text { Arquivo público de } \\
\text { informações cadastrais } \\
\text { privadas }\end{array}$ & $\begin{array}{c}\text { Cadastro de referência de } \\
\text { atos individuais privados } \\
\text { de efeitos públicos }\end{array}$ & Acesso ao cadastro \\
\hline $\begin{array}{c}\text { Arquivo público de } \\
\text { informações de } \\
\text { interesse para a } \\
\text { segurança do Estado e } \\
\text { da sociedade }\end{array}$ & $\begin{array}{c}\text { Cadastro de referência e } \\
\text { dados do governo }\end{array}$ & Sigiloso \\
\hline
\end{tabular}




\begin{tabular}{|c|c|c|}
\hline $\begin{array}{c}\text { Banco de dados de } \\
\text { informações cadastrais } \\
\text { privadas }\end{array}$ & $\begin{array}{c}\text { Cadastro de caráter } \\
\text { público sobre atos } \\
\text { individuais privados de } \\
\text { efeitos sociais }\end{array}$ & $\begin{array}{c}\text { Sigiloso } \\
\text { Aberto ao cadastro }\end{array}$ \\
\hline \multicolumn{2}{|l}{ Fonte: BASTOS; ARAÚJO, 1989, p.27 }
\end{tabular}

Desde a criação deste quadro em 1989, houveram algumas mudanças significativas no cenário de acesso à informação no país. Em 2000 a lei de responsabilidade fiscal-lei complementar 101 de 2000- começaria a mudar a forma que a administração pública deveria se comportar em relação a divulgação de seus atos.

Em 2009 a lei complementar 131 acrescenta dispositivos à lei 101, estabelecendo procedimentos de divulgação de despesas e receita para conhecimento da população.

Após nove anos em tramitação no Congresso, a Lei de Acesso à informação-Lei 12.527 de 18 de novembro de 2011- foi aprovada, representando a adesão do país a um novo regime de informações, demostrada pela adesão de vários países nesse sentido. É interessante destacar aqui, que na mesma data de promulgação da Lei de Acesso à Informação, também foi promulgada a Lei de Criação da Comissão Nacional da Verdade (Lei 12.528), com o intuito de abrir os arquivos de processos do período da ditadura militar brasileira (1964-1985), para desvendar os abusos cometidos pelo Estado contra desaparecidos e condenados políticos. Mas, mais do que isso, com o intuito de oferecer uma resposta aos familiares das vítimas desses abusos. Destaco este fato aqui, por não se tratar apenas de uma coincidência de datas, mas pelo fato de que a Lei de Acesso à Informação disponibiliza ferramentas para que esta investigação de uma passado tão sombrio e oculto seja possível. Este fato deixa claro a sinalização de que o acesso à informação abre portas para a democracia, indo em sentido contrário a regimes totalitários.

Segundo Frota (2013, p.79), "[...] a atual Lei de Acesso à informação trata da questão do sigilo, mas inclui também diversas normas e os procedimentos necessários à viabilização do acesso à informação governamental pelos cidadãos". Para atender essa demanda do cidadão comum, foi recomendado através dessa mesma lei, a criação de serviços de informação ao cidadão (SICs), e quando oferecidos em meio digital, chamados de "e-SIC". Neste sentido a Lei nos faz refletir sobre o uso de ferramentas tecnológicas para facilitar o acesso do usuário. $O$ acesso remoto pode ser então uma boa solução para atender a demanda de informações de interesse público. Pensar em serviço de referência virtual como forma de mediação para que a informação chegue de forma mais natural e rápida ao cidadão é uma necessidade para o crescimento dos serviços oferecidos pelos arquivos e na função desempenhada diante da sociedade pelos arquivistas. Quando digo, que a informação precisa chegar de forma mais natural, é para destacar o valor da função de mediador que o arquivista deve exercer. De acordo com Batista (2013, p.145), "[...] no processo de apropriação da 
informação estão envolvidos sujeito e objeto numa relação dialética na qual o sujeito torna seu um objeto do mundo, transformando-o em uma expressão de si, num elemento simbólico constitutivo de sua identidade". Ou seja, no processo de busca e compreensão de uma informação, ou do mundo, o sujeito precisa se sentir inserido na realidade abordada, precisa se sentir parte do mundo investigado, em um processo de atribuição de significado ao conhecimento adquirido, para que de fato possa fazer mudanças na sua forma de compreender as coisas.

A mediação cultural então "é uma ação de produção de sentido que se contrapõe à intermediação e à transmissão neutra de signos. O arquivista então, assumindo sua postura de mediador, coloca o sujeito (cidadão) e o objeto (informação), em uma relação em que o sujeito não se sinta estranho ao objeto, tornando esta relação mais 'familiar"'

Ainda há muito o que avançar neste sentido, mas a regulamentação de uma lei de acesso à informação é um prenúncio de uma vontade de caminhar rumo a promoção de cidadania e de concretização de uma democracia plena.

Taylor (1984 apud COSTA, 2011, p. 27) divide o acesso em dois aspectos: físico e intelectual. $\mathrm{O}$ acesso físico em arquivos públicos é orientado por medidas relativas à constituição do acervo que envolve a avaliação e aquisição de conjuntos documentais, e por requisitos operacionais, tais como horário de funcionamento, existência de sala de consulta, serviço de reprodução e serviço de informação. O acesso intelectual é dependente das operações arquivísticas de tratamento do acervo, da disponibilidade de meios de recuperação e do profissional envolvido. "Acesso físico e acesso intelectual são, portanto, complementares" (TAYLOR, 1984 apud COSTA, 2011, p. 27).

O que Taylor divide em físico e intelectual, Duchein (1983, p. 7) denomina de condições materiais, e enumera alguns fatores que dificultam ou impedem o acesso aos arquivos públicos (COSTA, 2011, p. 27):

- A necessidade de conservar em bom estado o documento de arquivo;

- A limitação de fornecimento de cópias a fim de proteger esse material;

- A dificuldade de se elaborar instrumentos de pesquisa suficientemente pormenorizados para que todos possam tomar conhecimento da existência do arquivo e de seu conteúdo;

- A limitação de dias e horários para funcionamento das salas de consulta e número insuficiente de empregados destinados ao atendimento do usuário;

- O difícil manejo de equipamentos necessários para consultas à documentação especial, como, por exemplo, leitoras de microfilmes. 
Conforme observamos, as restrições podem ser reduzidas ou ampliadas em razão da existência ou ausência e padrões de gerenciamento informacional, bem como da disponibilidade de recursos humanos, materiais e tecnológicos.

Honório e Damasceno (2006 apud COSTA, 2011, p. 28) consideram prejudiciais os limites burocráticos a que são submetidos os arquivos públicos tais como: horário de atendimento limitado ao horário comercial; deficiência dos instrumentos de controle intelectual dos fundos arquivísticos depositados nos arquivos permanentes; deficiências na interação entre arquivo público, custodiador dos documentos de valor permanente, e administração pública produtora e responsável pelos documentos em fase corrente e intermediária; falta de espaço físico e condições adequadas de armazenamento e preservação; carência de infraestrutura para atendimento ao usuário. Costa (2011), ainda destaca que soma-se a esses fatores a falta de infraestrutura dos arquivos públicos, comum em países como o Brasil, para a organização dos seus acervos.

Um outro fator importantíssimo levantado por Costa (2011), é a falta de habilidade do usuário em utilizar os instrumentos de recuperação da informação nos arquivos: guias, catálogos, inventários e índices. Esses instrumentos de pesquisa são obras complexas, especializadas e de difícil elaboração a ponto de não serem inteligíveis aos usuários de arquivo. É por isso que o arquivista deve se sentir responsabilizado por essa incompreensão das ferramentas que elabora. Cabe ao profissional de arquivo, o treinamento do seu usuário para possibilitar que ele tenha acesso pleno à todas as informações disponíveis.

Diante do que foi exposto fica claro que nos últimos anos, o Brasil avançou no processo de democratização da informação. A implantação de leis e normas para que os arquivos se voltem para a questão do acesso é essencial. Mas é preciso que o governo continue buscando ferramentas para que a lei de fato funcione. Além de problemas burocráticos ainda existentes, a falta de estrutura e de profissionais qualificados ainda são fatores impeditivos importantes na questão do acesso. A necessidade de criação e aplicação de políticas de preservação e conservação dos acervos dos arquivos também é emergencial. Este momento é propício para buscas de soluções e renovação da esperança de um país que desfruta de uma democracia de fato e de direito.

\subsection{HISTÓRICO DOS ESTUDOS DE USUÁRIOS DA INFORMAÇÃO}

Estudos de usuários são investigações que se fazem para saber o que os indivíduos precisam em matéria de informação, ou então, para saber se as necessidades de informação por parte dos usuários de uma biblioteca ou de um centro de informação estão sendo satisfeitas de maneira adequada. (FIGUEIREDO, 1994, p. 7). 
Esta definição apresentada por Nice Figueiredo já demonstra a origem dos estudos de usuários vinculada à avaliação dos serviços de bibliotecas, o que pode estar ligado ao fato de que já na década de 1930, foram realizados estudos de comunidade por essas instituições.

A maioria dos estudos neste campo foi realizada a partir da segunda metade da década de 40. Na Conferência da Royal Society, em 1948, foram apresentados trabalhos que vieram contribuir para a preocupação em criar estudos orientados às necessidades dos usuários. A Conferência Internacional de Informação Científica, em Washington, em 1958, também muito contribuiu para o desenvolvimento desta área de investigação, com diversos trabalhos apresentados sobre o assunto. Este evento foi o ápice da preocupação em entender o comportamento de busca da informação dos usuários das ciências experimentais e de tecnologia, dedicando uma parte dessa reunião ao tema: "Literature and reference need sof scientists: knowledge now available and method sof acertaining requirements". O evento convidava os pesquisadores a desenvolver métodos para melhorar a disseminação da informação científica e criar instrumentos e serviços de referências mais eficazes, buscando levantar os pontos fortes fracos dos padrões atuais da comunicação científica (GONZÁLEZ TERUEL, 2005, p. 45).

$\mathrm{Na}$ década de 60 os estudos de usuários seguem principalmente duas linhas: a necessidade de conhecer o comportamento de busca de informação de outros tipos de usuários, diferentes do cientista, e a necessidade de obter resultados mais precisos que permitam melhoras concretas dos sistemas de informação. Os estudos desenvolvidos nessa época tratam de investigações que procuram conhecer o usuário e o processo de comunicação científica de forma mais detalhada, dentro de um determinado contexto, tentando relacionar suas necessidades de informação e o uso dessas informações com as tarefas desenvolvidas por eles. Isso aponta mais um avanço nos estudos de usuários. Mas, o fato mais importante nessa década é que neste momento começam a ser desenvolvidos estudos, investigando os cientistas sociais, grupo desconhecido até o momento. Esse desconhecimento se devia ao fato de que consideravam que esses cientistas tinham que trabalhar com um volume menor de informação. Mas com o desenvolvimento de diversos temas na área e com o aumento do volume de publicações, começam a ser criados os primeiros centros de informação especializados nesta área. Para que estes centros pudessem oferecer serviços de qualidade era preciso conhecer as necessidades de seus usuários.

Buscava-se conhecer detalhadamente o que ocorria em cada uma das fases do processo de comunicação científica: a produção da informação, transmissão, armazenamento e uso. O objetivo da série de investigações que foram realizadas foi obter informação sobre os ruídos no fluxo informacional, a estrutura e função das redes de comunicação formais e informais, a transferência de informação desde o domínio informal ao formal, e a correlação entre as características dos usuários e o uso dos vários meios de comunicação. $O$ 
desenvolvimento desses estudos permitiu conhecer um tipo heterogêneo de usuário, até então desconhecido, e estabelecer uma imagem rica em detalhes do seu comportamento na troca de informações. Permitiu ainda, a aplicação de métodos próprios das ciências sociais, que possibilitaram compreender melhor as necessidades e o uso da informação (GONZÁLEZ TERUEL, 2005, p. 51).

Menzel em 1966 aponta que diante da falta de qualidade de alguns trabalhos do passado, era necessário utilizar uma base teórica e metodológica voltadas para disciplinas como a sociologia e a psicologia. No entanto, Lipetz (1970) afirma que os avanços ocorridos com a incorporação destas disciplinas ainda se apresentam em um estado incipiente, sendo necessário um aprofundamento na elaboração dos métodos (GONZÁLEZ TERUEL, 2005, p. 51).

Lipetz (1970 apud GONZÁLEZ TERUEL, 2005) destaca que:

\begin{abstract}
[...] os anos seguintes deveriam trazer progresso e conhecimento das necessidades e uso da informação, mas provavelmente nada que revolucione imediatamente os métodos predominantes de trabalho e desenvolvimento dos sistemas de informação. O conhecimento do uso da informação abarca conceitos abstratos relacionados com a motivação humana que são difíceis de serem estabelecidos e aceitos de forma geral (LIPETZ, 1970 apud GONZÁLEZ TERUEL, 2005, p. 52, tradução nossa) $)^{3}$.
\end{abstract}

A década de 70 incluiu uma maior diversidade de grupos em seus estudos. Foi uma década "dedicada aos estudos das necessidades dos cientistas sociais, e dos altos escalões da administração governamental" (FIGUEIREDO, 1994, p. 9). No entanto, se fazem mais fortes as críticas sobre a falta de aplicação dos resultados e as deficiências metodológicas de investigação. Um importante fato na história dos estudos de usuários foi a criação no ano de 1975 do "Center for research on users studies" na Universidade de Sheffield por iniciativa da "British Library Research and Development Departament'. A criação desse centro de estudos foi devido à tradição e investigação nesta área de sua pós-graduação, atualmente denominada "Departamento of Information Studies". "A motivação principal para a sua criação foi a falta de habilidade no uso das técnicas de investigação social e dos investigadores junto com a necessidade de fomentar uma uniformidade no uso da metodologia" (GONZÁLEZ TERUEL, 2005, p. 52, tradução nossa) ${ }^{4}$.

Entre os estudos realizados neste centro de pesquisa, se destaca o INISS (Information Needs and Services in Social Services Departaments), que marca os estudos de usuários nas estratégias e métodos empregados. "Este estudo tinha como objetivo investigar o comportamentos e os hábitos de informação dos trabalhadores sociais britânicos com a 
finalidade de obter uma imagem de suas necessidades que pudesse servir para determinar quais serviços de informação seriam mais eficazes" (GONZÁLEZ TERUEL, 2005, p. 53, tradução nossa) $)^{5}$. Em um primeiro momento foram realizadas uma série de visitas aos departamentos administrativos para que a equipe de investigação conhecesse de maneira mais profunda a estrutura organizacional e os serviços de informação que estavam disponíveis. Depois, foi realizado um estudo de observação e entrevista com vinte e dois indivíduos, com escalas de trabalho diferentes. Os resultados obtidos foram transformados em melhorias que foram incorporadas aos serviços de informação para atender e antecipar as necessidades de informação dos usuários (GONZÁLEZ TERUEL, 2005).

Com os esforços desprendidos nos anos anteriores, a década de 1980 foi marcada pela atenção especial dada ao desenvolvimento teórico e metodológico nos estudos de usuários. Essa tendência foi citada por Dervin e Nilan (1986) no "Annual Review of information science and technology", onde realizaram uma revisão de literatura dos trabalhos anteriores, destacando a mudança de orientação sofrida por estas pesquisas, passando de um modelo tradicional voltado para os sistemas, para um modelo centrado no usuário. Os estudos centrados nos sistemas consideravam o usuário com um receptor passivo de informação, sem considerar os aspectos que influenciam seu comportamento no processo de busca da informação. O modelo centrado no usuário atribui a ele um papel ativo na busca de informação, de tal maneira que o valor atribuído à informação depende de sua percepção. De acordo com Fidel (2000), o modelo centrado no usuário, busca mais que ensinar ao usuário como utilizar um sistema de busca de informação, trata-se de descobrir como o usuário busca a informação, e a partir daí, desenvolver sistemas que se adaptem às suas necessidades.

Dervin e Nilan (1986) identificaram um problema nos estudos tradicionais sobre necessidades e uso da informação. Trata-se de uma falta de definição e delimitação de conceitos fundamentais presentes no processo de busca da informação. De acordo com os autores, este problema acabou impedindo a construção de um marco conceitual apropriado para este tipo de investigação. Por este motivo, vários autores, no início dos anos oitenta se esforçaram para identificar estes problemas e desenvolver alternativas. Esses esforços resultaram no desenvolvimento de uma série de modelos e teorias com diversas formas de investigação no campo das necessidades e uso.

Brenda Dervin (1983), desenvolveu a teoria Sense-Making, onde se considera que cada indivíduo tem uma imagem do mundo que vai variando conforme vai adquirindo diferentes informações. Por isso é centrada no modo que o usuário utiliza a informação ao longo do processo. Essa teoria apresenta um processo de busca da informação, constituído

5Idem, p. 53. Original na língua inglesa. 
por três elementos: uma necessidade, em um tempo, e em um espaço, que define o contexto que os problemas de informação surgem.

Wilson (1981), desenvolveu um modelo para explicar a motivação que leva o usuário a buscar informação. Seu modelo de comportamento de busca da informação (information see king behaviour), considera as necessidades psicológicas, cognitivas e afetiva do indivíduo, como necessidades básicas das quais derivam as necessidades de informação.

Além dos modelos de Dervin e Wilson, Elis (1989), descreve o processo de busca de informação de cientistas sociais e engenheiros, a partir de uma série de características comuns que os definem. O modelo propõe que se formos capazes de definir o tipo de comportamento de cada indivíduo no processo de busca da informação, será possível adaptar o sistema de recuperação a este comportamento intuitivo do usuário.

Carol Kuhlthau (1991) caracteriza o processo de busca da informação com a sucessão das seguintes etapas: iniciação, seleção, exploração, formulação, coleção e apresentação. Da mesma forma que Elis, Kuhlthau tenta estabelecer possíveis padrões de comportamento de busca da informação, neste caso para determinar o tipo de intervenção necessária por parte das unidades de informação diante das necessidades dos usuários. O trabalho de Kuhlthau é baseado na Information Literacy ou Competência Informacional.

De acordo com Dudziak (2010, p. 5), “[...] a expressão Information Literacy (literalmente traduzida como alfabetização informacional) surgiu pela primeira vez na literatura em novembro de 1974, em um relatório intitulado: 'The information service environment relation ships and priorities', de autoria do bibliotecário americano Paul G. Zurkowski que era, naquele momento, o Presidente da "Information Industry Association" (IIA), e integrava a equipe da "National Commission on Libraries and Information Science". A meta de Zurkowski e sua equipe era estabelecer as diretrizes para um programa nacional de preparação e acesso universal à "Information Literacy", que seria concluído até 1984. Este direcionamento teve origem nas constatações feitas por Zurkowski em seu próprio ambiente de trabalho." Para compreender melhor o significado deste conceito, será utilizado a definição da ALA (American Library Association), de 1989 que diz que:

Para ser competente em informação, uma pessoa deve ser capaz de reconhecer quando uma informação é necessária e deve ter a habilidade de localizar, avaliar e usar efetivamente a informação. [...] Resumindo, as pessoas competentes em informação são aquelas que aprenderam a aprender. Elas sabem como aprender pois sabem como o conhecimento é organizado, como encontrar a informação e como usá-la de modo que outras pessoas aprendam a partir dela. (ALA, 1989, p. 1).

Ainda de acordo com Dudziak (2010), 
[...] o relatório da ALA ressaltava a importância da InformationLiteracy para indivíduos, trabalhadores e cidadãos, reforçando o papel da informação na resolução de problemas e tomada de decisão. As recomendações se concentraram na implantação de um novo modelo de aprendizado, com a diminuição da lacuna existente entre sala de aula e biblioteca. (DUDZIAK, 2010, p. 7).

Apesar de todo o contexto do desenvolvimento de todo processo de competência informacional apresentar seus maiores estudos ligados à biblioteca, de forma especial à biblioteca escolar, as suas metodologias podem ser utilizadas em qualquer ambiente que tenha um usuário que tenha que aprender a lidar com informação. De modo que treinar o usuário de arquivo, para que ele aprenda a buscar informação, para que ele exerça sua cidadania tendo acesso às informações a que the cabe, o torna mais capaz diante da resolução de problemas ou tomada de decisão, são todas as características que definem o aprender a aprender. E é de fundamental importância a participação do arquivista neste processo.

De acordo com González Teruel (2005, p. 57), o desenvolvimento desses modelos possibilitou:

- Delimitar, definir e relacionar os diferentes aspectos do processo de busca da informação;

- Foi possível estabelecer as diferenças entre os variados modelos de investigação de estudos centrados no usuário, desde o ponto de vista de seus objetivos, até a aplicabilidade de seus resultados;

- Permitiu sistematizar o nível de abstração da investigação;

- O uso de uma base teórica permitiu utilizar um marco de referência para interpretar o comportamento do usuário diante de sua necessidade de informação;

- Permitiu estabelecer uma relação entre teoria e investigação empírica, de tal maneira que a teoria guia a investigação e esta alimenta a teoria. (tradução nossa).

$\mathrm{Na}$ década de 1990, os marcos teóricos e metodológicos desenvolvidos nos anos 80 são reconhecidos e incorporados às novas investigações. Nessa década surgem cada vez mais eventos voltados à discussão dos estudos de usuários e uso da informação. Dentre eles destaca-se o "Information Seeking in Context", iniciado em 1996 e celebrado posteriormente a cada dois anos. Os estudos apresentados focam cada vez mais a importância de considerar a vida social, a historicidade, a influência do ambiente, as organizações e as culturas no processo de busca da informação do indivíduo.

Nesse momento ocorrem uma "popularização" da internet e o aumento do uso da Web como fonte de informação. Esse novo cenário demonstra que existem vários usuários que não necessitam de um mediador para ter acesso à informação. Isto leva os pesquisadores a tentar adaptar os diferentes modelos desenvolvidos a este novo quadro e encontrar um modo de 
atender esse "usuário virtual". Um exemplo é o trabalho desenvolvido por Choo, Derlor e Turnbull (1998), que criaram um modelo de comportamento informacional na Web, baseado, entre outros, no modelo proposto por Ellis (1989).

Já são mais de 60 anos de investigação sobre as necessidades e uso da informação. Atualmente, o que se pode afirmar é que os estudos estão numa fase de consolidação diante os diversos modelos adotados. Pode ser considerado também como o campo da biblioteconomia e da documentação que mais tem desprendido esforços dos pesquisadores para o desenvolvimento de uma base teórica consolidada.

Os resultados dos estudos de usuários, embora nem sempre generalizáveis, oferecem, contudo, uma visão ampla dos problemas e tendências dos usuários na consulta das bibliotecas e/ou de suas coleções (FIGUEIREDO, 1994, p. 13). Vale lembrar que essa constatação de Figueiredo pode ser aplicada a qualquer unidade de informação, incluindo também os arquivos.

O estudo da demanda e das necessidades de informação dos usuários pode ser realizado através da aplicação de questionários, entrevistas, observação direta (onde o investigador observa a ação do usuário), e através do controle da interação do usuário com os sistemas computadorizados. Este controle de sistemas automatizados possibilita conhecer o comportamento do usuário, a atuação do sistema, levantar estatísticas sobre o uso do vocabulário para busca, frequência de uso de um documento, inclusive o tempo gasto na busca. De acordo com Figueiredo (1994, p. 11), esses dados coletados podem revelar:

- Deficiências ou insuficiências do sistema representadas pela alta revocação de documentos não relevantes ou baixa revocação do documentos relevantes;

- A necessidade de aprimoramento da estratégia da busca, a fim de evitar dificuldades para os usuários na operação do sistema;

- Necessidade de alteração das políticas de indexação, de desenvolvimento de vocabulário, e de dar importância a maior uniformidade, inclusão de dispositivos de precisão, etc.;

- Necessidade de treinar os usuários nos processos de pesquisa;

- Atualização dos requisitos dos perfis;

- Frequência de descritores e, portanto, assuntos que se acham em demanda ou mudança de interesses.

Os estudos de usuários, mesmo apresentando algumas limitações, de acordo com Figueiredo (1994, p. 26) apontam algumas constatações relevantes:

- Acessibilidade e facilidade do uso são os fatores mais determinantes para a utilização ou não de um serviço de informação; o canal mais acessível, embora não o melhor, é 
escolhido primeiro e assim, considerações sobre qualidade e confiabilidade são secundárias. Por outro lado, a percepção da acessibilidade da informação por parte do usuário, é influenciada pela experiência pessoal, ou seja, quanto mais experiência no uso de um canal, mais ele se torna acessível para o usuário;

- Muitos profissionais sentem existir um volume excessivo de informação, isto é, existe na realidade mais informação do que a desejada. Nesse caso o que é solicitado então é que haja seletividade por parte do sistema de informação. Esta seletividade é caracterizada pela produção de revisões críticas da literatura e por avaliação e síntese da informação adequada, em áreas especializadas de assunto;

- Há necessidade de que a informação fornecida seja corrente, especialmente na área das ciências. Os serviços de informação precisam assim disseminar de maneira mais rápida e eficiente os resultados de pesquisas científicas;

- Os canais informais de comunicação são considerados mais importantes do que os canais formais para satisfazer muitos tipos de necessidades de informação. Arquivos pessoais têm demonstrado ser de grande importância pois, como muitos estudos mostraram, são a fonte primeira de busca. Vem a seguir a preferência pela conversa com os colegas na própria instituição e fora dela. Somente após estes passos iniciais é que a biblioteca (ou outra unidade de informação) será considerada. A preferência pelos arquivos pessoais é justificada por retratarem o interesse individual do cientista e serem fáceis de manusear, estarem em local conveniente e serem constantemente atualizados. As conversas com colegas, por outro lado, propiciam a troca de ideias entre cientistas com os mesmos interesses e, acima de tudo, propicia o "feedback" imediato, ou seja, a aprovação dos pares, tão importantes nas ciências;

- A educação do usuário ou de usuários em potencial é uma área negligenciada;

- A falta de promoção ou de marketing adequado para os produtos elaborados pelos serviços de informação é outro problema relacionado com a negligência na educação do usuário.

As constatações apontadas por Figueiredo demonstram a pouca evolução dos estudos iniciais em relação ao estado atual dos estudos sobre o tema na arquivologia. $\mathrm{O}$ arquivista ainda negligencia a educação dos usuários e não apresenta para o mesmo, os serviços oferecidos pelo arquivo. Os estudos de usuários de arquivos, ainda se encontram em um estado incipiente. Lancaster (1979), relata algumas observações importantes para planejadores e administradores de sistemas de informação e que são resultados de estudos de usuários:

- Diferentes usuários em potencial têm necessidades diferentes de informação e as necessidades de um mesmo indivíduo podem sofrer grande variação com o tempo; 
este tipo de problemas foi clara e amplamente demonstrado nos estudos de relevância/pertinência;

- De maneira semelhante, a utilidade de um documento é relativa não somente à combinação do assunto deste documento com os interesses do usuário, mas são importantes também as variáveis de nível, língua, formato da informação;

- Deve haver um acompanhamento ou a possibilidade de o sistema de informação propiciar a acessibilidade ao documento, isto é, obter a cópia desejada, e não somente fornecer a referência bibliográfica e deixar ao usuário o problema da localização do documento;

- É necessário que o usuário tenha confiança no serviço de informação; para que isto seja alcançado, é necessário que haja continuidade na prestação de serviços e que o pessoal tenha capacidade para dialogar inteligentemente com o usuário;

- Existe evidência de que muitos indivíduos não reconhecem ter necessidade de informação e se reconhecem isto, podem não ter contudo capacidade de converter ou traduzir esta necessidade em demanda a um serviço de informação.

Os estudos de usuários são úteis para não somente conhecer as necessidades de seus usuários reais, mas também de seus usuários potenciais ou não-usuários. De acordo com Lancaster apud Figueiredo (1994, p. 41), em muitas situações, são conhecidas apenas as demandas dos usuários atuais, pouco ou nada é sabido das necessidades de informação dos que não estão fazendo uso do serviço de informação. E destaca ainda que nem todas as necessidades dos usuários são convertidas em demanda. Essa dificuldade se dá porque nem sempre as necessidades expressas pelo usuário refletem as suas necessidades reais. Então, "existe um fator bastante perturbador: os serviços podem ser dirigidos mais para as necessidades expressas e afastadas das necessidades reais, atrás das expressas; e das necessidades dos usuários reais que não são nunca convertidas em demandas" (FIGUEIREDO, 1994, p. 42).

Figueiredo ainda destaca que o não usuário é aquele indivíduo que não conhece o produto oferecido, não podem encontrar o produto, não precisa do produto, não entende o que seu produto pode fazer por ele, não espera um bom serviço, não confia na sua marca ou não conhece a sua marca (FIGUEIREDO, 1994, p. 43).

Dessa forma a autora destaca que para transformar um não usuário em usuário basta que o profissional informe o que a unidade de informação tem para oferecer para ele, fazê-lo confiar no produto oferecido e fornecer não somente respostas, mas respostas úteis a ele.

No tópico seguinte será abordada a trajetória dos estudos de usuários na arquivologia e de que forma esses estudos podem ajudar na promoção do acesso aos arquivos. 


\subsection{OS ESTUDOS DE USUÁRIOS NA ARQUIVOLOGIA}

A discussão sobre os usuários em arquivos começou na década de 1960, sendo discutido em três grandes eventos: Conselho Internacional de Arquivos: o Congresso Extraordinário, realizado em Washington, em 1966; a X Conferência da Table Rounde, que ocorreu em Copenhagen, em 1967; e o VI Congresso Internacional, que aconteceu em Madri no ano de 1968 (SILVA et al., 1998). E ganhou força na década seguinte. Mas mesmo assim, duas décadas depois, a temática continuou sendo muito pouco expressiva no âmbito do conhecimento científico gerado na Arquivologia.

Segundo Araújo (2013), na década de 1980, basicamente duas linhas de pesquisa se delinearam. Por um lado, desenvolveram-se estudos para garantir maior acesso aos documentos arquivísticos, por meio da eliminação de barreiras (DUCHEIN, 1983), criação de instrumentos de recuperação (DOOLEY, 1992 apud ARAÚJO, 2013) e maior conhecimento dos interesses dos públicos (PUGH, 1982 apud ARAÚJO, 2013). De outro lado, desenvolveuse um conjunto de estudos que buscaram perceber, na prática de estudos com usuários, uma reorientação da prática profissional como um todo, de forma a que os resultados desses estudos interferissem nas demais ações e práticas arquivísticas (JIMERSON, 1989apud ARAÚJO, 2013). Essas duas linhas acabaram por aproximar os arquivos das temáticas de necessidade de informação.

De acordo com Ávila e Souza (2011),

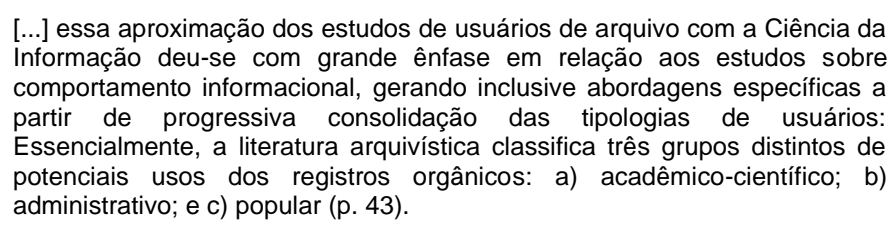

Dentro de novas demandas provocadas por uma chamada "sociedade da informação", nos últimos anos temos vivenciado, em diversos níveis e realidades sociais, vários aspectos resultantes da ampliação do uso das tecnologias da informação e da comunicação. Esse processo vem moldando novas dimensões às relações políticas, econômicas, culturais entre indivíduos, grupos sociais e Estados. A emergência de práticas inéditas de produção, transferência e uso da informação abre possibilidades ilimitadas para seu uso e oferta, envolvendo um conjunto cada vez mais amplo e "anônimo" de indivíduos (JARDIM; FONSECA, 2004, p. 2). De acordo com Jardim (1999):

- O conceito de "lugar" torna-se secundário para o profissional da informação e para os usuários; 
- Onde a informação se encontra não é o mais importante e sim o acesso à informação;

- A ênfase na gestão da informação desloca-se do acervo para o acesso, do estoque para o fluxo da informação, dos sistemas para as redes;

- Instituições como arquivos, bibliotecas e centros de documentação adquirem novas vocações, renovam funções que the são históricas e superam outras;

- Sob a banalização das tecnologias da informação, os usuários (aos menos os não excluídos do acesso às tecnologias da informação), produzem novas demandas aos arquivos, bibliotecas, centros de documentação e provocam a realocação ou supressão de fronteiras que demarcam tais espaços;

- Emergem espaços informacionais virtuais (bibliotecas, arquivos. etc.) cuja existência, longe de excluir as instituições documentais tradicionais, sugereIhes novas possibilidades de gestão da informação.

Segundo Jardim e Fonseca (2004) do ponto de vista dos impactos deste contexto no universo arquivístico, alguns autores sugerem que não apenas necessitamos nos movermos em direção a um paradigma da pós-custódia arquivística, mas também partirmos do modelo "arquivos direcionados para os arquivistas" para "arquivos direcionados para os usuários". É cada vez mais ressaltado que arquivistas não servem aos arquivos, mas à sociedade e seus diversos agentes. No Congresso Internacional de Arquivos de 1996, assinalava Ketellar:

Aqui estamos nós, 2500 arquivistas juntos, conversando uma semana inteira sobre a nossa profissão. Mas onde estão os usuários, nossa razão de ser? Eles estão do lado de fora, num mundo que nós não podemos ver porque não há janelas, não há janelas neste salão, não há janelas nos depósitos arquivísticos, não há janelas em nosso pensamento profissional. (KETELLAR, 1996).

Esta reflexão de Ketellar chama a atenção para a necessidade de uma arquivologia cada vez mais centrada no usuário. Como lembra-nos Tálamo (1996, p. 12), “[...] a informação é inseparável do sujeito, tanto daquele que a gera, como daquele que a transforma e a trata, como daquele que a recebe e a aplica, transformando-a ou não em outros conteúdos". De acordo com Wilson (1995) estamos efetivamente, no limite de uma necessária e vital transformação na disciplina e nas práticas arquivísticas.

Em um estudo de Jardim e Fonseca (2004), onde procuravam mapear os estudos sobre estudos do usuários em arquivologia, seus resultados detectaram que:

- A literatura arquivística sobre estudos de usuários é pouco expressiva quando comparada a outros temas como transferência de documentos, avaliação, arranjo e descrição, etc; 
- A preocupação com o acesso à informação é evidente, reiterando o compromisso ético-profissional do arquivista com este tema. A ênfase, porém, encontra-se nos aspectos legais, oferta de instrumentos de pesquisas, normalização, etc;

- A noção de acesso à informação arquivística tende a estar mais relacionada aos atributos do arquivista e aos deveres da instituição arquivística do que a um processo de transferência da informação que envolve necessariamente a participação do usuário.

- De maneira geral, o usuário não se configura como sujeito do processo de transferência da informação e sim como objeto (nem sempre explicitado) do acesso à informação;

- $\quad$ No que se refere aos estudos de usos e usuários de arquivos não se plasma uma literatura que aprofunde este tema do ponto de vista teórico e prático;

- $\quad$ A preocupação com o acesso aos arquivos não parece estar calcada numa perspectiva efetivamente dialógica envolvendo arquivista, arquivos e usuário;

- Os estudos tendem privilegiar o usuário do arquivo permanente, sem contemplar as especificidades que envolvem os usos e usuários das demais fases do ciclo vital arquivístico,

- $\quad$ Parece ocorrer no campo arquivístico algo semelhante ao que menciona Le Coadic (1997, p. 7) quando aborda a questão no campo da Biblioteconomia e da Documentação, ou seja, inicialmente procuraram-se respostas

[...] aos problemas colocados pelas coleções (constituição, crescimento, classificação, catalogação, conservação), depois aqueles colocados pelas biblioteca em si, enquanto serviço organizado (regulamento, pessoal, contabilidade, local, mobiliário) e somente por último, os problemas colocados pelos leitores, pelos usuários.

- Sem minimizar os mecanismos que determinam o predomínio da difusão de conhecimento em nosso campo, aparentemente é no âmbito da literatura arquivística norteamericana que a questão do usuário mostra-se mais enfatizada.

Esses aspectos apontam para uma arquivologia mais preocupada com a gestão arquivística, com os problemas de classificação, com legislação e menos voltada para o acesso de usuários. No Brasil, na pesquisa de Jardim e Fonseca (1999) sobre a produção e difusão de conhecimento arquivístico no país nos anos 1990, revela que dos 109 artigos, comunicações e relatos de experiência publicados, apenas um tem como tema central os usos e usuários dos arquivos. Esta baixa produção científica sobre o tema pode ser também um reflexo da ausência ou da pouca importância dada ao tema nos cursos de graduação em arquivologia. Kurtz (1990) em um trabalho abordando a temática de estudos de usuários em arquivos, destaca alguns aspectos que podem explicar a pouca discussão sobre o tema, dentre eles, o autor destaca: "[...] a pouca ênfase da formação de arquivistas no estudo dos usuários e usos dos arquivos." 


\begin{abstract}
A ausência do tema se reproduz também nos principais manuais da área, ao contrário do que ocorre em obras deste mesmo teor na área de Documentação e Biblioteconomia, nas quais verifica-se frequentemente um capítulo voltado para as necessidades informacionais e estudos de usuários. (JARDIM; FONSECA, 2004, p. 6).
\end{abstract}

Dowle (1992) sugere uma agenda de investigação sobre a disponibilidade e uso dos arquivos: "[...] se os arquivistas desejam compreender o mecanismo das práticas arquivísticas e as razões dos princípios e teorias, devemos dirigir nossa atenção dos acervos físicos ao uso da documentação." Para tal, Dowle sugere que os arquivistas busquem nas Ciências Sociais e na teoria da informação os marcos conceituais e métodos para investigar os diversos aspectos da prática arquivística. Recorrendo a Freeman, Dowle assinala: "[...] devemos começar a aprender de maneira sistemática e não por simples impressões como fazemos agora quem são nossos usuários... temos de pensar a administração de arquivos como uma administração centrada no cliente e não nos materiais". Na sua perspectiva, identificar não só o uso real bem como o uso potencial de arquivos ("comunidade de usuários") é fundamental: "[...] as perguntas colocadas pelos usuários, os métodos que utilizam e inclusive os usos potenciais são tão importantes como o conhecimento sobre o que realmente se utiliza".

Outro fator importante é em relação às definições do termo usuários na arquivologia. Diferente da biblioteconomia e da documentação, o próprio arquivista em alguns casos é considerado também como usuário, o que Silva (2011) chama de "usuário do lado de dentro do balcão ou agente público", já que em muitas instituições, o arquivista realiza a função de gestor da informação, mas também é função dele consultar as informações com o auxílio das ferramentas desenvolvidas por ele mesmo. Ao se recorrer a alguns dicionários arquivísticos nacionais, percebeu-se que o termo usuário está ligado àqueles que consultam arquivos permanentes, conforme exposto no Quadro 14. No Dicionário Brasileiro de Terminologia Arquivística (2005, p. 159) usuário é definido como a "[...] pessoa física ou jurídica que consulta arquivos. Também chamada consulente, leitor ou pesquisador". (PORTELLA; PEREZ, 2011, p.4).

\title{
QUADRO 15
}

Dicionário

Associação dos Arquivistas

Brasileiros(1990)

Camargo e Bellotto (1996)

Arquivo Nacional (2005)
Terminologia

\section{Definição}

Pessoa que consulta ou pesquisa documentos num arquivo.

Pessoa que consulta ou pesquisa documentos num arquivo.

Pessoa física ou jurídica que consulta documentos de arquivo. Também chamada de consulente, leitor ou pesquisador. 
Cunha e Cavalcanti (2008

Fonte: SILVA, 2011, p.11
Pessoa que consulta os documentos de um arquivo. Erroneamente denominado leitor.

As definições apresentadas acima permitem notar que:

\begin{abstract}
[...] o perfil daqueles que recorrem aos documentos de arquivo é estabelecido de acordo com a idade do documento procurado, mas pelo viés da terminologia usuário. Aqueles que recorrem aos arquivos correntes e intermediários são definidos como usuários que exercem suas funções na própria instituição e que necessitam da documentação para dar continuidade as suas atividades ou para comprová-las. Já os usuários que recorrem ao arquivo permanente são em grande parte pesquisadores que buscam documentos cujo valor já não mais corresponde à finalidade para a qual foi produzido/ acumulado institucionalmente, mas sim às potencialidades informacionais vinculadas a fins científicos, sociais ou culturais. (SILVA, 2011, p. 12).
\end{abstract}

Ávila e Souza (2011), ainda apresentam de forma mais aprofundada o perfil de cada tipo de usuário de arquivo. Segundo os autores, existe um usuário interno que se caracteriza por solicitar ao arquivo o cumprimento das funções básicas que dele se espera; organizar, transferir e tornar acessível a documentação. Quanto aos usuários externos, são definidas quatro categorias: os investigadores profissionais, os investigadores aficionados, os estudantes e os cidadãos em geral.

Os investigadores profissionais se direcionam ao arquivo com o intuito de satisfazer suas necessidades intelectuais ou de estudo, tendo uma formação universitária definida. "Além disso, querem ter acesso à documentação sem a ajuda dos documentos de descrição. Porém são mais pacientes e familiarizados com os serviços" (ÁVILA; SOUZA, 2011, p. 42). Em contrapartida os investigadores aficionados têm uma formação variável e por isso apresentam necessidades estranhas aos arquivos. Por isso, sentem-se muitas vezes frustrados por não conhecer o funcionamento e a realidade da instituição. A categoria dos estudantes geralmente busca os documentos de arquivo devido a um trabalho de curso. "Chegam à instituição sem uma preparação prévia e sem o contato anterior com as técnicas e metodologias de investigação" (ÁVILA; SOUZA, 2011, p. 42). Isso acaba gerando impaciência, ao observar que o trabalho requer tempo para execução. Os autores ainda destacam a falta de cuidado desse tipo de usuário com o documento, que na realidade é um patrimônio histórico.

Os cidadãos em geral são descritos como aqueles que realizam consultas esporádicas nos arquivos, e a aparição desse grupo se relaciona ao direito de acesso à informação. "Muitas vezes se equivocam na maneira como veem tais serviços por considerá-los um 
departamento administrativo, negligenciando os conceitos de patrimônio documental que estão atrelados a esta fase" (ÁVILA; SOUZA, 2011, p. 43).

Mas seja qual for o perfil do usuário, Portella e Perez $(2011$, p.2) destacam que:

\begin{abstract}
O arquivista, como profissional da informação deve disponibilizá-la para quem dela precisar, independentemente do perfil do usuário do arquivo. Compreender e prever o seu comportamento, hábitos e necessidades são vitais para que a infraestrutura adequada ao seu pleno acesso à informação seja concretizada, satisfazendo as suas necessidades de informação, além de buscar a continua melhoraria da qualidade do atendimento (PORTELLA; PEREZ, 2011, p.2)
\end{abstract}

De acordo com Ávila e Souza (2011), as concepções apresentadas para usuário na arquivística guardam uma estreita vinculação com o receptor dos documentos da fase permanente. Borrás (2001), assevera que estas concepções acabam por não fazer menção a outras categorias de usuários externos e, sobretudo, excluem os próprios produtores dos documentos ou usuários internos da organização. Borrás (2001), aprofunda as definições sobre os usuários internos e os divide em três categorias: a) os diretores, que planejam e supervisionam os procedimentos administrativos; b) os responsáveis pelas unidades administrativas, que coordenam junto com os arquivistas os sistemas de gestão de documentos, e; c) aqueles que executam diretamente a implantação da gestão. Segundo Borrás, o arquivista deve coordenar suas ações em conjunto com todos esses atores do ambiente interno.

Blais (1995 apud ÁVILA; SOUZA, 2011, p. 43), ressalta que com a democratização de acesso às informações arquivísticas resulta a aparição de um novo estrato aos sistemas de arquivo, que a autora designa como "usuário-cidadão". Além dessa categoria, a autora especifica um grupo a mais: o "pesquisador-amador". "O principal motivo para o contato desse usuário com o arquivo é a sua curiosidade pessoal por grandes fatos e eventos históricos" (BLAIS, 1995 apud ÁVILA; SOUZA, 2011, p. 43).

No contexto atual em que vivemos, a valorização da informação traz uma exigência ao arquivista: não vincular os serviços do arquivo apenas aos documentos permanentes, mas também aos documentos correntes e intermediários.

A utilização dos estudos de usuários nos arquivos pode ajudar de forma bastante significativa no avanço das discussões sobre o acesso. A afinidade entre arquivista e usuário se estabelece no atendimento direto realizado pelo profissional, seja na sala de consulta, no atendimento à distância, por meio de telefone, correio, correio eletrônico ou fax; na disponibilização dos documentos para consulta; na reprodução e no empréstimo de documentos. Nestes contatos o arquivista deve estar atento às manifestações do usuário e fazer bom uso delas. De acordo com Couture (2003, p. 374), "[...] além da atenção ao usuário que se dirige ao arquivo, o arquivista deve implementar ações de difusão, acenando para um 
público potencial. Para tanto, o profissional que lida com público deve atuar na promoção de conferências e palestras relativas aos arquivos e a sua utilização, organizar workshops sobre metodologia de pesquisa, preparar exposições, etc".

O profissional do arquivo deve também ter uma boa fluência na sua comunicação com o usuário. Essa capacitação, segundo Costa (2011), deve incluir:

\begin{abstract}
[...] o desenvolvimento de uma percepção holística do indivíduo para a interpretação das suas necessidades de informação; o aprimoramento da capacidade de percepção do mundo de informações em que o atendente está inserido e o estímulo à compreensão do universo que está do lado de fora do balcão de atendimento, pois é nesse espaço externo que são forjadas as lacunas, dúvidas e a demanda pela informação. (COSTA, 2011, p. 29).
\end{abstract}

A utilização de sistemas informatizados vem ajudar os arquivos na preservação do documento, que poderá ser acessado em meio digital, garantindo o cumprimento de deveres e o respeito aos direitos dos cidadãos. $O$ arquivista neste caso deve atuar de forma a moldar sistemas amigáveis aos usuários. A padronização de linguagem contribui também de forma significativa para a eficiência da gestão de documentos.

\begin{abstract}
É preciso haver um padrão, mas não um padrão imposto com o qual as pessoas não se identifiquem, e sim um padrão construído que leve em consideração os termos já utilizados, estabelecendo-se correspondências entre as diferentes linguagens, por exemplo, na elaboração de instrumentos de gestão, de instrumentos de pesquisa e sistemas informatizados de gerenciamento arquivístico de documentos. (SILVA, 2011, p. 15).
\end{abstract}

Os estudos de usuários surgem então, de acordo com Figueiredo (1994), com os seguintes objetivos:

- Verificar por que, como e para que os usuários usam a informação;

- Verificar quais fatores afetam o contexto de uso destas informações; e,

- Prever a demanda de informações e realizar mudanças no sistema informacional de modo a agilizar o atendimento.

Voltando-se para a organização dos arquivos, é importante lembrar que em cada uma das suas três idades, o uso da informação e os usuários possuem peculiaridades que os diferenciam. De acordo com Paes (2007, p.20), os arquivos são classificados de acordo com:

- As entidades mantenedoras;

- Os estágios de sua evolução;

- A extensão de sua atenção;

- A natureza dos documentos." (PAES, 2007, p.20) 
E em relação aos documentos, lembra que eles podem ser ostensivos ou sigilosos. Sendo que os documentos sigilosos são aqueles que sua divulgação não prejudica a administração. É importante destacar as peculiaridades dos documentos, para que fique claro que a produção e toda a gestão de documentos nos arquivos dependem, além de normas e regras de classificação, de uma legislação que define sua destinação e acesso. A definição e sua destinação e de quem pode acessá-lo influencia diretamente nas políticas a serem desenvolvidas em cada tipo de arquivo.

Paes (2007, p.35), apresenta as etapas de trabalho, que segundo a autora, são necessárias para a organização dos arquivos:

- Levantamento de dados;

- Análise dos dados coletados;

- Planejamento;

- Implantação e acompanhamento." (PAES, 2007, p.35)

Pode-se observar que entre as etapas apresentadas não existe uma que seja dedicada de forma exclusiva aos usuários, ou que proponha estudos para conhecer suas necessidades. Apenas na fase de planejamento que o usuário é citado, mas não aprofunda-se no estudo do tema. De maneira geral os manuais de arquivologia estão mais voltados para a gestão de documentos, esquecendo-se da presença do usuário. Comprovando esta afirmação, Paes (2007) apresenta os seguintes pontos indispensáveis nos manuais da área:

- Apresentação, objetos e abrangência do manual;

- Informações sobre os arquivos da instituição, suas finalidades e responsabilidades; sua interação e subordinação;

- Organogramas e fluxogramas;

- Conceitos gerais de arquivo, definição das operações de arquivamento; terminologia;

- Detalhamento das rotinas, modelos de carimbos e formulários utilizados; planos de classificação de documentos com seus respectivos códigos e índices;

- Tabelas de temporalidade de documentos, que, pela sua amplitude, pode ser apresentadas em separado." ( PAES, 2007,p.51)

Os arquivos correntes são aqueles que estão em uso constante pela administração pública ou instituições privadas, onde a busca pelo documento é exigida de forma imediata pelo usuário.

Os arquivos intermediários e permanentes encontram-se em grande parte nas instituições públicas em face do grande volume de documentação oficial e de sua descentralização física. As empresas e entidades de caráter privado dificilmente necessitam desse organismo, salvo no caso de instituições de grande porte (PAES, 2007, p. 50). 
Já os arquivos intermediários, são constituídos de documentos que já não estão mais em uso corrente e estão aguardando sua destinação, de acordo com cada tipo de documento para serem descartados ou encaminhados para arquivos permanentes. Nesta fase apenas as entidades produtoras é que tem acesso aos documentos.

A função de um arquivo permanente é reunir, conservar, arranjar, descrever e facilitar a consulta dos documentos oficiais, de uso não-corrente, ou seja, concentrar sob sua custódia, conservar e tornar acessíveis documentos não-correntes, que possam tornar-se úteis para fins administrativos, pesquisas históricas e outros fins. Por ser resultado da reunião de arquivos de vários setores, sua administração é bem mais complexa.

A autora destaca nesta fase a necessidade da criação de instrumentos de pesquisa que terão como função "[...] orientar os usuários nas diversas modalidades de abordagem a um acervo documental." (PAES, 2007, p.126).

Sobre os arquivos permanentes Bellotto $(2002$, p.3) destaca que:

\begin{abstract}
Sua herança na comunidade deve se fazer sentir, seja como aglutinador dos especialistas-pesquisadores das áreas atinentes ao seu acervo, seja como animador de atividades culturais locais, principalmente nas pequenas cidades. $\mathrm{O}$ arquivo público permanente, voltando-se para fora de suas paredes para inteirar-se com a população, inclusivamente quanto a angariar os documentos privados, testemunhos de histórias-de-vida, cumpre seu papel centralizador de informações da evolução administrativa e social do meio a que serve.
\end{abstract}

Tendo em vista as características dos documentos e dos usuários em cada um dos estágios de evolução dos arquivos, deve-se destacar que o "usuário" está sempre presente. Cada um com suas peculiaridades, mas o fato é que o documento está lá, e será solicitado em algum momento, e o arquivista deve estar pronto no exercício de dar acesso de forma eficiente e eficaz, preocupando-se principalmente na elaboração de ferramentas de organização e recuperação da informação capazes de atender a cada uma dessas peculiaridades. Essa compreensão só é possível a partir da aproximação e da compreensão de seus clientes, é neste ponto que os estudos de usuários trazem uma mudança de paradigma nos arquivos.

\title{
5 SISTEMATIZAÇÃO E ANÁLISE DAS ENTREVISTAS
}

Para se obter um maior entendimento a respeito da importância dos estudos de usuários na formação do arquivista e do lugar de disciplinas voltadas para tais estudos nos 
currículos dos cursos de arquivologia, aplicou-se uma entrevista semi-estruturada ${ }^{6}$ à professores e coordenadores dos cursos de arquivologia. Inicialmente foi feito contato com coordenadores e professores dos dezesseis cursos de Arquivologia oferecidos no país, porém apenas representantes de oito cursos de diferentes universidades se disponibilizaram a participar: Universidade Júlio Mesquita- Campus Marília, Universidade Federal do Espírito Santo, Universidade Federal de Minas Gerais, Universidade de Brasília, Universidade Federal Fluminense, Universidade Estadual de Londrina, Universidade Federal de Santa Maria e Universidade Federal do Amazonas.

Dos dezesseis cursos existentes atualmente, apenas um, o da Universidade Federal Fluminense (UFF) não oferta uma disciplina voltada para Estudos de Usuários em seu currículo. A disciplina é ofertada como obrigatória nos cursos da Universidade Federal de Santa Maria(UFSM), Universidade Estadual de Londrina (UEL), Universidade Federal do Rio do Sul(UFRGS), Universidade Júlio Mesquita-Campus Marília (Unesp), Universidade Estadual da Paraíba (UEPB), Universidade Federal do Rio Grande (FURG), Universidade Federal de Minas Gerais (UFMG), Universidade Federal de Santa Catarina (UFSC) e Universidade Federal do Amazonas (Ufam). É ofertada na modalidade optativa na Universidade Federal do Estado do Rio de Janeiro(Unirio), Universidade de Brasília (UnB), Universidade Federal da Bahia (UFBA) e na Universidade Federal do Espírito Santo (UFES). Sendo que em dois cursos são ofertadas duas disciplinas voltadas para a temática dos Estudos de Usuários: na UFBA; com as disciplinas "Marketing em serviços de informação" e "Ação cultural e educacional nos arquivos"; e na UFES; onde são ofertadas as disciplinas "Estudo de público da Informação" e "Estudo de Usuário". A duração das disciplinas em todos os cursos variam de 30 a 60 horas.

O Quadro 16 mostra o nome adotado em cada curso, em sua respectiva instituição de ensino. Além da expressão "Estudos de Usuários", aparecem também em seus títulos as palavras “Marketing”, "Difusão", “Usuários da Informação" e "Estudo de Público".

\section{QUADRO 16}

Nome das disciplinas voltadas para "Estudos de Usuários" nos cursos de Arquivologia:

\begin{tabular}{|c|c|}
\hline Instituição & Nome da Disciplina \\
\hline UFSM & Marketing \\
\hline
\end{tabular}

\footnotetext{
${ }^{6}$ Conforme anexo 1
} 


\begin{tabular}{|c|c|}
\hline UFF & Não oferece nenhuma disciplina voltada para Estudos de Usuários \\
\hline Unirio & Uso e Usuários da Informação \\
\hline UnB & Estudos de Usuários \\
\hline UFBA & Marketing em Serviços de Informação/Ação Cultural e Educacional nos \\
& Arquivos \\
\hline UEL & Estudos de Usuários de Biblioteconomia e Arquivologia \\
\hline UFES & Estudo de Público da Informação/ Estudo de Usuários \\
\hline UFRGS & Difusão em Arquivos \\
\hline Unesp & Serviços e Usuários da Informação em Arquivos \\
\hline UEPB & Usos e Usuários da Informação Arquivística \\
\hline FURG & Estudo de Uso e Usuários da Informação \\
\hline UFMG & Estudos de Usuários de Arquivo \\
\hline UFPB & Não informado \\
\hline UFSC & Estudo de Usuários da Informação \\
\hline UFAM & Estudo de Usuários \\
\hline UFPA & Não informado \\
\hline
\end{tabular}

Fonte: Elaborado pela autora

Após análise do conteúdo das entrevistas, foram elaboradas 11 categorias: 1)Habilidades Profissionais, 2)Formação Acadêmica, 3)Harmonização dos currículos, 4)Acesso, 5) Sociedade e Arquivo 6)Ações de Marketing e mediação cultural, 7)Uso e Usuários de Arquivos, 8)Usuário remoto, 9) Desenvolvimento dos Estudos de Usuários na Arquivologia, 10) Contribuições dos Estudos de Usuários para a Arquivologia, e 11) Bibliografia para Estudos de Usuários.

\subsection{CATEGORIAS}

Neste capítulo serão apresentadas trechos das transcrições das entrevistas agrupadas em cada uma das categorias criadas seguidas de uma análise que busca relacionar os resultados obtidos com o referencial teórico levantando até o momento. Os entrevistados receberam um código de identificação (E1, E2, E3, E4, E5, E6, E7, E8). É importante destacar que o código criado não está relacionado com nenhuma instituição ou pessoa, sendo utilizado apenas para diferenciar os participantes.

a) Habilidades Profissionais: 
Nesta categoria foram relatadas quais as habilidades profissionais que 0 arquivista deve ter para atender as demandas da sociedade atual.

Dos oito entrevistados, quatro destacaram as habilidades relacionadas a gestão documental conforme demonstra o trecho abaixo:

[...] Então, a visão que se tinha era muito essa, de uma pessoa responsável por ser o guardião da documentação, digamos assim. Hoje, eu percebo... e aqui no Brasil, como a gente não tem essa diferenciação do arquivista e do eco management, então na verdade você é formado para atuar nas 3 fases, nas 3 áreas, mas eu percebo uma tendência pra que o arquivista esteja mais voltado realmente para a gestão [...] (informação verbal) ${ }^{7}$.

Outro entrevistado também deixa claro a importância da habilidade de saber gerir documentos:

O arquivista hoje, a maior parte dos profissionais que lida com arquivologia, os nossos egressos, eles vão atuar especialmente nos arquivos correntes e intermediários. Então, um conteúdo que hoje a gente considera fundamental é a questão da gestão de documentos, para a grande maioria dos alunos... ainda que a gente conheça a importância de trabalhar com os arquivos permanentes, mas sem conhecer todo o ciclo de vida do documento, o arquivista não tem condição de se formar, mas a grande maioria deles vai atuar com gestão de documentos (informação verbal) ${ }^{8}$.

b) Competência Social

Em três entrevistas, destacou-se entre as habilidades necessárias para o arquivista contemporâneo, além de sua habilidade como gestor, no processo de gestão documental, uma habilidade que vamos chamar de competência social, pois destaca sua atuação direta na sociedade:

[...] E uma competência na visão e na percepção das questões sociais, das questões culturais. Porque o arquivo presta um serviço de grande importância para a sociedade, então, nesse sentido, ele tem que ter uma formação, uma competência, pra atender ou pra responder a essa demanda social dos arquivos (informação verbal) ${ }^{9}$

Então, independente do currículo, o projeto pedagógico do curso de arquivologia deve primar por essas três dimensões: a dimensão técnica, que é no caso das disciplinas; a dimensão social; e a dimensão do senso crítico, que o formado em arquivologia, o arquivista, deve ter (informação verbal) ${ }^{10}$.

c) Diálogo interdisciplinar:

Apenas um entrevistado destacou além da habilidade de gestor, uma necessidade de desenvolver-se habilidades profissionais a partir do diálogo com outras áreas do conhecimento:

Ele não pode ter o conhecimento somente prático, mas também o conhecimento teórico, e que possibilite discutir com outras áreas do

\footnotetext{
7 E3

${ }^{8} \mathrm{E} 1$

9 E8

${ }^{10} \mathrm{E} 4$
} 
conhecimento nessa questão da interdisciplinaridade, com a História, com a Sociologia, com a Administração, que ele realmente se sinta o gestor de documentos e não simplesmente um técnico.

Apesar de por vezes haver variações em certas categorias de habilidades, a necessidade do arquivista ser um gestor de documentos aparece nas respostas de todos os entrevistados.

É importante destacar que ao explorar este tema, inevitavelmente volta-se para a reflexão sobre a definição do que é um arquivista, quais são suas funções dentro do arquivo e diante e da sociedade.

Conforme foi levantado neste trabalho, o Conselho Internacional de Arquivos traz uma definição de Arquivista como um profissional responsável por organizar e gerir o documento dentro dos arquivos. A Sociedade dos Arquivistas Americanos em suas diretrizes de procedimentos e condutas dos arquivistas destaca o esforço que o profissional deve empenhar para garantir o acesso aos usuários de arquivos.

No primeiro caso, pode-se considerar uma definição que refere-se à Arquivologia como uma área mais preocupada com a custódia e preservação de acervo, dialogando de forma bastante clara, com os depoimentos de quatro entrevistados que destacaram em seus relatos a gestão documental como algo essencial no conjunto de habilidades de um bom profissional. Em contrapartida, três entrevistados destacaram, o que denominou-se de acordo com a estrutura das categorias criadas, de "competência social", pois destaca a necessidade desse profissional se preocupar com as necessidades da sociedade. A Associação dos Arquivistas Quebequenses em suas diretrizes sobre as funções a serem desenvolvidas por estes profissionais também destaca a sua função social, relacionando a preservação da memória, e aqui pode-se entender memória como documento, com a garantia e promoção de cidadania conferindo de maneira clara a necessidade da "competência social".

É importante destacar que para se permitir o acesso é preciso também contar com uma gestão documental bem feita em todas as suas fases, são etapas complementares dentro de qualquer unidade de informação. A "competência social" então é uma atitude complementar a todo o processo de gestão nos arquivos. Conforme já foi destacado por Taylor (1984), o acesso intelectual é dependente das operações arquivísticas de tratamento do acervo, da disponibilidade de meios de recuperação e do profissional envolvido. Acesso físico e acesso intelectual são, portanto, complementares.

Um entrevistado fala sobre a importância de um "Diálogo interdisciplinar" como parte da habilidade profissional do arquivista, algo talvez muito mais ligado à formação acadêmica e à construção dos currículos de formação. Mas é claro que a formação também reflete sobre o conjunto de habilidades, já que o currículo funciona como "molde" profissional. O entrevistado destaca a importância do diálogo com a História, Administração e Sociologia, 
como forma de enriquecimento e fortalecimento do campo, contribuindo de forma significativa em questões relacionadas à gestão, à pesquisa e preservação da memória.

Diante das informações que foram apresentadas ao longo da pesquisa e com os relatos dos entrevistados pode-se concluir que o profissional deve ser um bom gestor, conhecer bem as normas e técnicas aplicadas aos arquivos, assim como também deve conhecer das leis que regem essas instituições, e tudo isso, deve estar associado à uma constante preocupação com o usuário, no intuito de promover o acesso e ao mesmo tempo preservar a memória e a história de um povo.

\title{
e) Formação acadêmica:
}

Nesta categoria foi investigado se a formação atual oferecida nas universidades, na visão dos entrevistados consegue atender as demandas e habilidades profissionais exigidas pelo cenário atual.

Dois oito entrevistados, três responderam que consideram que o curso na sua situação atual em suas respectivas universidades conseguem formar profissionais capazes de atender a todas as demandas exigidas do arquivista na nossa sociedade atual: "[...] o currículo do curso, eu considero muito bom. É abrangente, amplo, conseguiria dar conta de todos os objetivos" (informação verbal)11 ; "Hoje, a gente atende, mas digamos que o aluno precisa de um esforço a mais para chegar a essas competências que eu te disse" (informação verbal) ${ }^{12}$. Outro entrevistado destaca:

\begin{abstract}
Hoje com o novo currículo, a gente buscou exatamente atender essa nova demanda, as demandas principais da área. Inclusive a questão de lidar com documento eletrônico, que é uma necessidade que antes o profissional de arquivo não precisava e que hoje ele é essencial. Então, com a adequação do currículo, a gente atende sim. Atualmente, sim (informação verbal) ${ }^{13}$.
\end{abstract}

Três entrevistados consideram que os cursos em suas respectivas unidades não conseguem formar profissionais capazes de atender as demandas atuais: "Não, eu acho que não. Pelo menos na nossa universidade, hoje a gente tem um tronco comum que privilegia mais o estudante de Biblioteconomia do que o de arquivologia" (informação verbal) ${ }^{14}$.; "Eu acho que ainda existe uma deficiência muito grande" (informação verbal) ${ }^{15}$; "Olha, eu acho que quem disser que o curso está bem, que atende tudo, é meio perigoso. Eu acho que deve haver sempre uma certa inconformidade, a gente sempre querendo melhorar mais e mais" (informação verbal) ${ }^{16}$.

$$
\begin{aligned}
& { }^{11} \mathrm{E} 4 \\
& { }^{12} \mathrm{E} 8 \\
& { }^{13} \mathrm{E} 1 \\
& { }^{14} \mathrm{E} 2 \\
& { }^{15} \mathrm{E} 3 \\
& { }^{16} \mathrm{E} 6
\end{aligned}
$$


E ainda dois entrevistados, disseram não saber responder, conforme mostra o trecho: "Eu não sei... eu não tenho tanta experiência pra saber" (informação verbal) ${ }^{17}$.

É importante destacar que ainda nesta categoria um dos entrevistados atribui o formação acadêmica deficiente oferecida pelo curso ao seu currículo atual:

Ele (o currículo) foca muito mais naquilo que se entende comum às duas áreas, que é o arquivo e a biblioteca, mas ele não explora áreas que são muito específicas pra quem trabalha com arquivo, com documento de arquivo, como por exemplo, História, Administração, Direito (informação verbal) ${ }^{18}$.

Outro entrevistado atribui essa deficiência à questões de "administração do currículo": "O problema é a administração desse currículo, é como as coisas acontecem no cotidiano, no dia a dia. As coisas parecem que desencontram, não fecha, não harmoniza" (informação verbal) ${ }^{19}$.

Esta categoria relaciona-se de forma direta com a categoria anterior, onde portanto busca-se traçar um paralelo para entender melhor a questão das instituições e um deslocamento de lugar de produção do conhecimento e desenvolvimento de habilidades para as universidades.

Esta categoria relata as falas dos entrevistados a respeito do diálogo entre as instituições de ensino e o mercado de trabalho, entre as demandas sociais atuais e o tipo de profissional que o currículo atual dos cursos está formando. O currículo não é imutável, assim como a sociedade também não é, e portanto o currículo deve refletir em sua estrutura as necessidades de uma época, apesar de neste momento ainda ser difícil explicar quem reflete quem, mas pode-se dizer que a sociedade sendo composta por atores sociais em constante mutabilidade de desejos, necessidades e ideologias influencia de maneira direta a formação educacional de maneira geral e também, no caso especifico deste trabalho na formação profissional.

A partir da década de 1990 acentua-se no Brasil a preocupação com as questões relacionadas à construção do currículo, principalmente após a aprovação da Lei de Diretrizes e Bases de Educação de 1996, que deu maior flexibilidade às instituições na construção de seus currículos que não estariam mais presos a uma grade curricular mínima, que por vezes acabou por engessar o avanço de pontos importantes na educação, impedindo que houvesse uma harmonia entre as necessidades sociais e a formação oferecida.

Três entrevistados afirmam que os cursos aos quais estão vinculados conseguem formar profissionais capazes de atender às demandas sociais, e quando afirmam isso, podese recorrer a categoria anterior onde descrevem as habilidades que consideram importantes 
no desempenho da atividade profissional. Destaca-se isso devido ao fato de que de acordo com as habilidades consideradas necessárias, terá então uma formação que seja adequada às mesmas. Estes entrevistados ainda ressaltam que mesmo os seus respectivos cursos conseguindo atender as necessidades atuais, não se deve deixar de estar atento para futuras mudanças, reconhecendo então a mutabilidade social e consequentemente a necessidade de haver uma mutabilidade do currículo.

Outros três entrevistados consideram que seus respectivos cursos não conseguem atender as demandas sociais atuais, sendo que um atribui essa não adequação devido a um currículo ainda baseado em um "tronco comum", onde o curso de Arquivologia ainda divide muitas disciplinas com o curso de Biblioteconomia, não se preocupando com as especificidades de formação do Arquivista. O que leva o tema também para uma reflexão sobre quais habilidades são inerentes aos profissionais que lidam com a informação de maneira geral e o mais importante que é se elas realmente existem, e se existem de que maneira poderia adequar-se dentro dos currículos.

Um entrevistado atribui o não atendimento das demandas ao que chamou de "administração do currículo", que está relacionado à questões burocráticas de implantação dos currículos na instituição no qual atua. Além dos problemas burocrático-administrativos a que toda universidade e cursos estão sujeitos, a própria organização estrutural das instituições de ensino influenciam bastante na formação, pois em cada universidade o curso de apresenta vinculado a departamentos de História, Comunicação, Ciência da Informação e Arquivologia, que acaba se tornando um fator importantíssimo na construção da matriz curricular de cada curso.

Faz-se importante lembrar que grande parte dos cursos ainda passa por reformulação de seus currículos e este quadro pode ser alterado de maneira bastante rápida.

\section{f) Harmonização dos currículos}

Esta categoria avalia a resposta dos entrevistados em relação a posição de cada um diante de uma proposta de harmonização entre os currículos dos cursos de arquivologia no país.

Todos os entrevistados veem a harmonização entre os currículos dos cursos de arquivologia de maneira favorável, porém com ressalvas, destacando a importância de respeitar as especificidades regionais:

Eu acho que a harmonização tem que acontecer. A harmonização entre os currículos é um fator positivo. [...] Então, a harmonização tem que ir até um determinado ponto. Cada estrutura, cada universidade, cada escola tem um perfil diferente, então eu acho que esse perfil, essa especificidade tem que ser mantida (informação verbal) ${ }^{20}$. 


\begin{abstract}
Ah, é favorável sim. Precisa. Você tem que ter uma linguagem comum. Já basta que a abordagem vai ser sempre diferente em cada curso. Porque as pessoas são diferentes, as realidades de cada curso e de cada localidade são um pouco diferentes, então você vai ter abordagens diferentes (informação verbal) $^{21}$.
\end{abstract}

Um dos entrevistados favoráveis à harmonização ainda destaca que poderia ser mais que uma harmonização mínima do currículo: "Não precisa de ser mínimo, acho que pode ser mais que isso. Deve haver uma harmonização nos currículos, sem dúvida nenhuma, mas não precisa ser mínima. Mais da metade das disciplina no mínimo" (informação verbal)22.

Outro entrevistado, também favorável à harmonização, acha importante destacar a diferença entre os termos "harmonizar e equalizar": "[...] é bom fazer isso, distinguir 'harmonizar' de 'equalizar'. A ideia não é formar igual, e formar harmônico. São coisas diferentes" (informação verbal) ${ }^{23}$.

Um dos entrevistados ainda destaca que acha a proposta de harmonização favorável, mesmo tendo vivenciado uma experiência ruim no curso onde atua:

Só pra esclarecer, eu não acho que a harmonização possa ser prejudicial não, eu acho que, pela minha experiência, a forma como ele está organizado aqui na universidade, está sendo prejudicial. Isso é uma questão específica. Eu não conheço essa harmonização proposta pela Unesco. [...] Eu não acho que a gente tem deformar arquivista em caixinha, padronizado, igualzinho não. Cada instituição tem o seu contexto, cada local tem a sua especificidade, mas a gente tem que ter questões mínimas que sejam fundamentais para o arquivista, que a gente saiba que estão sendo cumpridas (informação verbal) ${ }^{24}$.

A harmonização dos currículos proposta pela Unesco em 1974, que levou para uma reflexão de aproximação entre arquivos, bibliotecas e centros de documentação. $O$ plano inicial não queria apenas determinar um ensino baseado em um tronco comum nos cursos de Arquivologia, Biblioteconomia e documentação, queria ir além: tinha como meta criar diretrizes que harmonizassem os serviços prestados dentro das unidades de informação. Durante a entrevista é possível perceber um certo receio em relação a esta proposta, por acreditar-se que seu objetivo era simplesmente "uniformizar" disciplinas básicas do currículo. Mas, é evidente que diante dos avanços conquistados até aqui no Brasil, principalmente após a Lei de Diretrizes e Bases da Educação de 1996, entenda-se essa proposta como um retrocesso.

Ao longo das décadas, principalmente a partir da década de 1990, essa proposta perde força, pois percebe-se a necessidade de flexibilizar o ensino. Reconhece-se a mutabilidade da sociedade e os novos anseios que ela imprime em todos os setores. 
Todos os entrevistados se declararam favoráveis a uma harmonização entre os currículos dos cursos de Arquivologia no país, desde que as especificidades regionais sejam respeitadas, visto que o Brasil é um país de dimensões continentais e com uma diversidade cultural imensa. Com a implantação do projeto Reuni do Governo Federal, o número de cursos de Arquivologia cresce no país, provocando a necessidade de conhecer a situação desses novos cursos e dos antigos também, não fazendo comparações, mas buscando a partir do que foi apresentado, delinear novas metas para a consolidação da Arquivologia como campo científico.

Os oito entrevistados destacaram também que é importante ter um currículo base para a formação de arquivistas. Um entrevistado declara que seria importante ter mais do que um currículo minimamente harmonizado, essa igualdade de formação deveria ser acima de $50 \%$ do currículo. Mas parece ser difícil precisar em números qual seria a quantidade ideal, visto que tem que se pensar nas especificidades regionais e nas questões internas de cada instituição ao qual os cursos estão vinculados.

A ideia não é criar um "currículo mínimo" para os cursos de Arquivologia, mas propor uma harmonia entre os cursos, facilitar o diálogo apenas e não criar novas grades curriculares. A criação de um novo currículo mínimo traria um retrocesso nos avanços conquistados a partir da flexibilização das matrizes curriculares. Além disso, estaria ferindo a autonomia das instituições de ensino no processo de construção do currículo dos cursos.

\section{g) Acesso}

Essa categoria demonstra quais são as barreiras que dificultam o acesso aos arquivos para os usuários atualmente e demonstra também seus relatos a respeito dos impactos ou avanços na área em decorrência da aprovação da Lei de Acesso à Informação em 2011.

Dos oito entrevistados, três atribuem como principal fator que dificulta o acesso aos arquivos, a falta de profissionais qualificados atuando nos arquivos. Um entrevistado enfatiza a falta de profissionais de forma muito clara.

Barreira principal é a falta do pessoal pra trabalhar os arquivos. No nível tanto técnico como no nível superior. O que está faltando é gente pra trabalhar e localizar o material para disponibilizar. Tem as exceções que nos salvam, né? Tem arquivos que tem bons profissionais que estão suprindo essa demanda, mas podia estar melhor (informação verbal) ${ }^{25}$.

Sendo que deste grupo, dois entrevistados, relacionam a falta de profissionais qualificados principalmente no tocante na relação com o usuário de arquivo:

Não. Eu acho que principalmente da questão de formação. Porque como ele nunca ouviu, na sua formação, que existe essa figura do usuário... ele sabe, sim, que ele precisa fazer um plano, que ele precisa fazer uma tabela, então os instrumentos para ele lidar com a gestão, isso é primordial, isso não pode faltar. Mas, a questão do usuário, como não é discutida, então acaba não sendo prioritário. Então é um desdobramento: ele não soube na formação, 
consequentemente ele não vai enfocar em primeiro plano o usuário. Isso, de certa forma, acaba prejudicando o Acesso (informação verbal) ${ }^{26}$.

O mesmo entrevistado acima, foi o único que citou a necessidade de criação de Serviços de Informação ao Cidadão, que já é prevista na Lei de Acesso à Informação: "O que a lei estabelece? Precisa ser criado um serviço de informação ao cidadão, chamado e-SIC." (informação verbal) ${ }^{27}$.

Nos arquivos permanentes eu acho que a gente ainda tem um problema de formação do profissional voltado ao usuário. Muito embora o termo usuário, do serviço de arquivo, do atendimento ao usuário esteja muito em voga nos últimos anos, a percepção que eu tenho é que o atendimento ao usuário é uma coisa que ainda fica em segundo plano. Os arquivistas ainda gostam muito mais de fazer serviços de organização do que serviços de atendimento. $E$ veem um valor maior nessas atividades de organização do que nas atividades de atendimento ao público. (informação verbal) ${ }^{28}$. (E5)

Outros três entrevistados atribuem como principal barreira ao acesso, à organização dos acervos:

\begin{abstract}
A falta de organização sem sombra de dúvidas. O arquivos é sempre o patinho feio da história, então a maioria das instituições não se preocupa com os arquivos, não se preocupa em tê-los organizados, não se preocupa de forma nenhuma nesse acesso, principalmente para o usuário que não é aquele que não produziu o documento. Então eu entendo que o maior problema hoje é a organização dessa informação pra você ter acesso." (informação verbal) ${ }^{29}$.
\end{abstract}

"A forma de tratamento do acervo, se você fala dos arquivos públicos, vão produzir instrumentos de pesquisa muitas vezes que o arquivista vai saber lidar, mas que não são adequados para o usuário, então isso é uma barreira" (informação verbal) ${ }^{30}$.E o mesmo entrevistado citado acima também destacou de forma clara a questão da responsabilidade do Estado como um fator que dificulta a organização e o acesso aos arquivos:

O serviço é organizar documentos, é ter a documentação organizada. Eu acho que às vezes a gente fica imaginando uma situação utópica, e quando você vai pra prática e vai conhecer a realidade dos arquivos intermediários no Brasil. Por não investir nos arquivos, sem dúvida, ele (o Estado) dificulta. Não entender a importância dos arquivos, sem esse investimento, não tem como ter acesso (informação verbal) ${ }^{31}$.

"Bom, a própria organização dos arquivos... Ao menos aqui é assim, os arquivos não possuem estrutura..." (informação verbal) ${ }^{32}$.

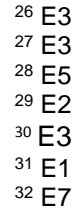


E os outros dois entrevistados atribuíram como principal barreira a falta de visibilidade dos arquivos diante da sociedade:

[...] quando se fala de informação arquivística, aquele que ainda não faz uso dos arquivos, o grande impedimento é a visibilidade que o arquivo não tem para a sociedade atual, para o cidadão comum. Então as pessoas não sabem onde fica o arquivo. $O$ arquivo em sua política de disseminação, de mediação, ele não tem ações que de alguma maneira consiga trazer esse público não usuário (informação verbal) ${ }^{33}$.

A gente é espionado pelos Estados Unidos, mas o cidadão brasileiro não tem acesso às informações mais relevantes do seu país. O cidadão brasileiro não... um pouco não se interessa, e outro pouco para que os nossos governantes se aproveitam disso pra deixar que a informação realmente não flua. (informação verbal) ${ }^{34}$.

Ainda, dentre esses, dois entrevistados também destacaram o período de atendimento dos arquivos como uma fator limitador ao acesso:

Então hoje o arquivo funciona-estou te dando o nosso exemplo aqui- o arquivo funciona num horário administrativo, de segunda a sexta, de meiodia às 17. Então, o cidadão comum não tem acesso a esse espaço, porque esse espaço não foi pensado para ele. [...] Quando ele coloca um horário administrativo, ele vai escolher apenas aqueles pesquisadores e não o cidadão comum que trabalha de segunda a sexta em horário administrativo (informação verbal) ${ }^{35}$

"[...] Bom, eu tentei marcar essa viagem com eles durante dois meses seguidos. Por que? Eles só atendem na quarta-feira, é o único dia da semana que eles atendem." (informação verbal) ${ }^{36}$.

\section{h) Serviço de Informação ao Cidadão}

Um entrevistado citou a necessidade de criação de Serviços de Informação ao Cidadão, que já é prevista na Lei de Acesso à Informação:

"O que a lei estabelece? Precisa ser criado um serviço de informação ao cidadão, chamado e-SIC." (informação verbal) ${ }^{37}$.

Sobre a Lei de Acesso à Informação, os entrevistados também relataram sobre o impacto da lei na Arquivologia e na prática do trabalho dentro dos arquivos.

As respostas podem ser divididas nos seguintes grupos:

1. Ainda não trouxe todas as mudanças necessárias:

Dos oito entrevistados, três acreditam que a lei não trouxe todas as mudanças esperadas, sendo que um deles, atribuiu a existência de algumas lacunas, à falta de mobilização do próprio profissional: "Olha, poderia ter contribuído mais. [...] Então eu acho 
que a gente poderia ter aproveitado mais a Lei de Acesso e a gente não aproveitou" (informação verbal) ${ }^{38}$.

O segundo entrevistado destaca, dentre as lacunas ainda existentes, a pouca importância ainda dada aos usuários, mais uma vez alertando para a atuação do profissional.

Eu acredito que a LAI tem um aspecto bastante positivo, no sentido que vem definir, diferenciar bem essa questão da categoria de sigilo. Mas, com relação ao usuário, ainda tem um outro trabalho, um outro percurso pra ser realizado, e que isso interfere basicamente na própria atuação do profissional arquivista também (informação verbal) ${ }^{39}$.

Outro entrevistado apenas destaca que ela deveria ser sinal de mudança, mas ainda há muito o que se fazer, destacando mais uma vez a atitude do profissional:

Ela deveria trazer. Eu acho que a área vem se posicionando e vem lutando para que isso aconteça. Ainda não é algo estabelecido, mas eu entendo que, em médio ou longo prazo, sim, se a gente se mobilizar e a gente trabalhar pra isso, a gente consegue o nosso espaço sim (informação verbal) ${ }^{40}$.

\section{Mudanças a longo prazo:}

Outros três entrevistados acreditam que a LAl traz mudanças para a área, mas a maioria ainda virá a longo prazo: "Ah, com certeza. Com toda certeza. Essa lei foi fundamental... não que tenha acontecido muita coisa, mas ela foi fundamental pra mudar um pouco o rumo disso no nosso país. Eu acho que ela traz muito impacto sim pra área de Arquivologia" (informação verbal) ${ }^{41}$.

"Traz, sem dúvida. Eu acho que não é um impacto de curto prazo. Não é um impacto de curo prazo, porque hoje todos os órgãos que estão se adaptando à lei estão criando um mecanismo de fornecimento de informação" (informação verbal) ${ }^{42}$.

Pois é. Foi um momento e uma oportunidade para os arquivistas se colocarem no mercado. Mais uma. [...] Na divulgação da lei, em tudo que a gente vê nas discussões em relação à lei, pouco se fala de arquivo, pouco se fala de documento. E aí, cabe a nós informar pras pessoas e fazer essa ligação [...] (informação verbal) ${ }^{43}$.

\section{Trouxe mudanças apenas na teoria:}

Um entrevistado afirma não ser possível ver ainda as mudanças na prática: “Teoricamente sim; na prática não. [...]. Nós estamos analisando aqui na universidade pra ver se depois dessa lei houve um aumento pelo menos da procura por informação da sociedade. E não houve" (informação verbal) ${ }^{44}$.

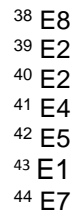


Outro entrevistado relaciona a Lei de Acesso à Informação ao acesso remoto e à digitalização de documentos:

O que eu percebo é que tem duas correntes mais fortes: Uma: tem pessoas que acham que a gente tem que pegar e digitalizar todos os documentos e disponibilizar na internet. [...] Outra coisa: a partir do momento que tu pegar e disponibilizar tudo na internet, não vai mais ter a figura do usuário presencial, só vai ter o usuário a distância, ou seja, vai perder totalmente o contato com o usuário. Eu sou de outra corrente. Eu sou da corrente em que tu tem que disponibilizar... algumas informações tu pode disponibilizar... tem de ver prazo, uma série de coisas. Mas, eu prefiro fisgar, ou atrair o usuário pra dentro do arquivo (informação verbal) ${ }^{45}$.

Nesta categoria observa-se o relato dos entrevistados a respeito de três temas centrais que envolvem as discussões sobre o acesso aos arquivos: as barreiras que dificultam esse acesso, a criação de um Serviço de Informação ao Cidadão, muito semelhante ao que é chamado de serviço de referência em outras unidades de informação, que é um serviço previsto na Lei de Acesso à Informação, e a Lei de Acesso à Informação propriamente dita, pontuando seus impactos, avanços e lacunas a serem preenchidas.

Antes, é importante lembrar que quando falamos em acesso aos documentos de arquivos, deve-se sempre preponderar as questões legais que regem esse assunto, visto que no Brasil, assim como em outros países, nem todos os documentos são de livre acesso, dependendo da sua classificação de sigilo e do tempo determinado para cada caso. E neste sentido, entende-se que também é papel do arquivista estar pronto para levar esse tipo de informação ao usuário, principalmente o cidadão comum que nem sempre tem conhecimento da legislação e consequentemente de seus direitos. Em alguns casos o cidadão até tem acesso ao que dia a lei mas por vezes não consegue compreendê-la, e é também papel do profissional ser um mediador da informação, procurando diminuir o máximo possível os ruídos, a falta de compreensão por parte do usuário.

Sobre as barreiras encontradas, Costa (2011) já destacava em seu trabalho alguns pontos importantes a serem considerados: a necessidade de conservar em bom estado 0 documento de arquivo; a limitação de fornecimento de cópias a fim de proteger esse material; a dificuldade de se elaborar instrumentos de pesquisa suficientemente pormenorizados para que todos possam tomar conhecimento da existência do arquivo e de seu conteúdo; a limitação de dias e horários para funcionamento das salas de consulta e número insuficiente de empregados destinados ao atendimento do usuário; e o difícil manejo de equipamentos necessários para consultas à documentação especial, como, por exemplo, leitoras de microfilmes. Das questões levantadas pelos entrevistados, algumas se alinham aos fatores levantados pelo autor. 
Três entrevistados apontam como principal barreira a falta de profissionais qualificados para atuarem nos arquivos. E de maneira específica, dentre esses entrevistados, associa de forma clara a falta de habilidade profissional, com a falta de habilidade em lidar com o usuário do arquivo. Conforme demonstrado no desenvolvimento do trabalho, a formação acadêmica precisa acompanhar as mudanças e os novos anseios da sociedade. E quando falamos em sociedade, não precisa-se necessariamente trabalhar com um pensamento "macro", podemos pensar em ambiente menor, como a cidade onde atua, o estado onde atua, a região onde atua. Continuando sobre a falta de habilidade levantada por um entrevistado, talvez se deva ao fato de os Estudos de Usuários ainda estarem em um estado de desenvolvimento ainda bastante inicial dentro das matrizes curriculares dentro dos cursos, em alguns casos ainda passando por ajustes, procurando encontrar a sua melhor forma.

Outros três entrevistados atribuem como barreira principal à falta de organização dos arquivos, destacando a falta de tratamento e de instrumentos de pesquisas capazes de atender todos os usuários. É hora de se pensar então, em incluir em todo o processo da gestão documental, um objeto central, onde todas as ações, todas as decisões serão direcionadas para ele: o usuário. Isso, é claro, inclui também o desenvolvimento de instrumentos de busca manuais ou digitais, amigáveis aos usuários e não apenas aos arquivistas. Mas, para isso, é necessário que o profissional esteja em contato direto com esse usuário, para conhecer sua linguagem, seu comportamento diante da informação. Neste grupo de entrevistados um atribuiu ao Estado, à sua falta de investimento nas instituições públicas, como fator importante para essa falta de organização dos arquivos.

Dois entrevistados atribuíram a falta de visibilidade dos arquivos diante da sociedade como principal fator que dificulta o acesso. Sendo que um pontua a responsabilidade dos profissionais e dos próprios arquivos nesse desconhecimento das pessoas em relação aos arquivos, destacando a ausência de ações que possam transformar o arquivo em um ambiente mais próximo da realidade do cidadão. O outro entrevistado relata que o desconhecimento sobre os arquivos é tão grande que não se vê com frequência na mídia os arquivos e os arquivistas. Mas pode-se pensar também que talvez seja papel do profissional trabalhar na construção da sua própria imagem e na divulgação da sua função e não esperar o contrário. Conforme já apontou Menne-Haritz (2001), o arquivo não funciona como uma "fábrica de memória", visto que a história é uma construção coletiva, e só existe memória a partir desta história vivida e contada. Mas os arquivos "criam memória", pois funcionam como uma prevenção para a amnésia. Ainda segundo a autora, o arquivo existe para responder as questões de uma sociedade, de seus conflitos sobre sua própria história.

O período de atendimento também foi apontado como um fator limitador de acesso, tanto referente aos dias, como também aos horários de funcionamento, que na maioria dos casos se limitam aos dias úteis em horário comercial, ou seja, um período que não consegue 
atender o cidadão comum, o trabalhador, que também necessita de informação, é a maior parte da população, mas por vezes não é lembrado no momento do planejamento de funcionamento das instituições. Costa (2011) também levantou a limitação do período de atendimento como um dos principais fatores que impedem o acesso entre aqueles que compõem os "limites burocráticos" a que são submetidos todos os arquivos.

Quanto ao Serviço de Informação ao Cidadão, previsto na Lei de Acesso à Informação, apenas um entrevistado relatou sobre a necessidade dos profissionais estarem atentos a sua implantação, justamente com o intuito de diminuir inúmeras barreiras de acesso que aqui foram relatadas. Um ponto tão importante e determinante da lei não poderia deixar de ser citado quando o assunto é facilitar o acesso, intensificar o uso e colocar o usuário como razão de ser do arquivo.

A Lei de Acesso à Informação, Lei no 12.527 representa não só uma evolução na história dos arquivos, mas uma revolução na história do país. O fato de termos promulgadas no mesmo dia uma lei de acesso e a lei de criação da Comissão Nacional da Verdade (lei no 12.528) demonstra a importância histórica e democrática dos arquivos, demonstra a necessidade de lembrar para não esquecer, de preservar para não se perder, mas principalmente promover um Estado transparente nas suas ações para que episódios de abuso e torturas ocorridos na Ditadura Militar não voltem a se repetir.

Os entrevistados então falaram sobre os impactos dessa lei nos arquivos e na prática profissional. Três entrevistados relataram que ainda não houve mudanças significativas devido a uma apatia profissional. Consideram que o profissional precisa se posicionar de maneira mais proativa, com uma visão apurada para oportunidades, mas principalmente para reconhecer sua responsabilidade para que as mudanças de fato ocorram. Duchein(1999), ao explicar o que é um arquivista, destacou que todas as suas atividades devem ser realizadas buscando "salvaguardar direitos e deveres das pessoas". Souza (2011) também chama a atenção do profissional, lembrado que deve-se associar à sua função de gestor, a sua função social, que se inicia desde o momento da produção documental e se estende até a difusão da informação. A prática dessas atitudes, por parte dos profissionais associadas a nova legislação podem colaborar para mudanças significativas nos arquivos.

Outros três acreditam em mudanças a longo prazo, talvez ainda porque as instituições e os profissionais ainda estão se ajustando para cumprir as determinações da LAI. Um entrevistado afirma que houve mudanças apenas na teoria e não prática, e relata o caso da instituição em que trabalhou, onde realizaram uma pesquisa para verificar a procura pelos arquivos após a promulgação da lei. Diante de uma constatação de que não houve aumento, o entrevistado entendeu que dessa maneira as mudanças ainda não ocorreram no plano prático. Mas o que ocorra neste caso talvez seja uma inversão dos papéis entre o profissional e o usuário. O profissional é quem precisa criar ações para alcançar o usuário potencial, é 
responsabilidade do profissional planejar e divulgar os serviços oferecidos. Sem essas ações torna-se praticamente impossível que a sociedade enxergue o arquivo como uma ferramenta para auxiliá-lo na construção de um Estado democrático pleno.

Um entrevistado relaciona a LAI com a digitalização de documentos e o acesso remoto, destacado que o número de usuários presenciais diminuiu. O entrevistado coloca isso de uma maneira negativa para os arquivos, preferindo trabalhar com usuários presenciais. Mas com todos os avanços das Tecnologias de Informação e Comunicação, e do aumento da inserção da população no ambiente digital, não se pode ignorar que é necessário desenvolver serviços voltados para o público virtual ou usuário remoto. Essa necessidade já foi manifestada em trabalhos anteriores, que aqui destaca-se o trabalho desenvolvido por Choo, Derlor e Turnbull (1998), que criaram um modelo de comportamento informacional na Web. Sobre o surgimento desse novo tipo de usuário, Jardim (1999) destacou que os usuários (aos menos os não excluídos do acesso às tecnologias da informação), produzem novas demandas aos arquivos, bibliotecas, centros de documentação e provocam a realocação ou supressão de fronteiras que demarcam tais espaços o que faz emergir espaços informacionais virtuais (bibliotecas, arquivos. etc.) cuja existência, longe de excluir as instituições documentais tradicionais, sugere-Ihes novas possibilidades de gestão da informação.

A pesquisa à distância trouxe inúmeras contribuições, de forma bastante especial para a pesquisa científica, facilitando a comunicação entre pesquisadores, a troca de informações e acelerou a comunicação dos resultados de pesquisas, ampliando também o acesso à informação, não sendo mais necessário que o usuário saia de casa para ter todo o conhecimento que deseja. É claro, que os serviços presenciais devem sim ser mantidos e melhorados, pois ainda está distante imaginar uma extinção da busca presencial em unidades de informação.

1. Sociedade e arquivo:

Quatro entrevistados_apontaram como veem hoje a relação da sociedade com os arquivos, com os documentos dos arquivos, identificando, na opinião deles, uma sociedade que ainda desconhece sobre seus direitos de acesso à informação: "A sociedade precisa dos documentos de arquivo. Agora, a sociedade não sabe dos arquivos, ela não sabe que precisa dos arquivos pra ter os documentos" (informação verbal) ${ }^{46}$.

Eu acho que a sociedade não tem... a maioria, pelo menos no nosso país, não tem nem conhecimento dos seus direitos de cidadão mínimos, e nisso se inclui até o seu direito de acesso à informação. Eu acho que não tem, não tem dos básicos, não tem também desses, até porque esse é mais recente, oficialmente (informação verbal) ${ }^{47}$.

Eu acho que o senso comum tem muita dificuldade de compreender isso. Isso é um processo longo. Então se você me disser que hoje a sociedade se 
importa com os documentos de arquivo, eu acho que ela se importa mais do
que há vinte anos atrás, por exemplo. Mas eu acho que ela ainda não se
importa o suficiente a ponto de perceber fortemente a importância de você ter arquivos organizados e o conteúdo que ele representa (informação verbal) ${ }^{48}$.

Então hoje a sociedade, a comunidade local... às vezes o sujeito mora na rua do arquivo e não sabe que o arquivo existe, que o arquivos está ali. Então eu acho que a fata de uma política de arquivo acaba sendo um motor que vai dificultar o acesso (informação verbal) ${ }^{49}$.

Dentre esses entrevistados que levantaram a relação da sociedade com os arquivos, um aponta a necessidade do arquivo se reconhecer como espaço de promoção de cidadania:

O arquivo ainda não se enxergou como esse espaço de cidadania de efetivação de cidadania. Nesse sentido tem esse desdobramento: ele continua escondido, porque ele não se coloca para a sociedade como espaço de reconhecimento, de identidade, porque ele quer servir apenas... ele escolhe o seu público, né? (informação verbal) ${ }^{50}$.

Quatro entrevistados levantaram a questão da relação do arquivo com a sociedade, relataram em seus discursos que o arquivo ainda é muito estranho para a maioria das pessoas, apesar de todos os avanços. O que é possível perceber em suas falas é que as pessoa inúmeras vezes já precisaram ou irão precisar de documentos de arquivos, mas elas não tem a consciência de que a informação que elas precisam estão nos arquivos.

Outro ponto importante levantado por um dos entrevistados é que em nosso país a maior parte das pessoas desconhecem os seus direitos básicos e isso inclui também o direito ao acesso à informação.

Pensando sob essa perspectiva é que deve-se pensar em um profissional que reúna habilidades em pensar socialmente para trabalhar como mediador da informação. Conhecer os direitos e deveres é só o princípio para que o indivíduo desperte para o reconhecimento de seu lugar na sociedade e para que ela descubra o tamanho da força que possui nas decisões de sua cidade, estado ou país. Retomando o que foi dito por Batista (2013) sobre a mediação cultural, deve-se destacar que no processo de busca e compreensão de uma informação o sujeito precisa se sentir inserido na realidade abordada, precisa se sentir parte do mundo investigado, em um processo de atribuição de significado ao conhecimento adquirido, para que de fato possa fazer mudanças na sua forma de compreender as coisas. A mediação cultural então "é uma ação de produção de sentido que se contrapõe à intermediação e à transmissão neutra de signos. O arquivista então, assumindo sua postura de mediador, coloca 
o sujeito (cidadão) e o objeto (informação), em uma relação em que o sujeito não se sinta estranho ao objeto, tornando esta relação mais "familiar".

Um entrevistado também nos leva para a reflexão de que para o diálogo entre a sociedade e os arquivos aconteça, é preciso um trabalho longo, com um resultado também a longo prazo, pois tudo é um processo. Destaca ainda que hoje o reconhecimento entre as duas partes é maior do que há vinte anos atrás, o que significa que o trabalho não pode parar, cada vez mais ações devem ser incorporadas na prática diária dos arquivos para ser um instrumento socialmente integrado.

E um entrevistado chama os arquivos para que se movam para se colocarem no lugar correto que é o de espaço promotor de cidadania, que conforme já bem colocou Menne-Haritz (2001), o arquivo não é detentor da memória, mas espaço de construção da memória coletiva.

2. Ações de Marketing e mediação cultural:

Essa categoria analisa as respostas dos entrevistados quando questionados sobre 0 que o arquivista poderia fazer para diminuir esse desconhecimento atribuído à sociedade, de forma mais específica, ao cidadão comum, sobre os arquivos.

Dos oito entrevistados, sete apontaram as ações de divulgação dos serviços dos arquivos através de todas as ferramentas disponíveis e ações de mediação cultural, buscando iniciar um processo de educação de usuários desde os primeiros anos escolares:

[...] não é só trazer as crianças pra ver. As pessoas que estão dentro e as pessoas que estão entrando ali estarão os futuros políticos, estarão os futuros dirigentes de instituições, estarão as pessoas que vão discutir, vão decidir o uso de recursos, públicos e privados. E a gente só gosta do que conhece. É impossível gostar de alguma coisa que se desconheça. A partir do momento que a gente está levando pra dentro dos arquivos essas crianças, nós estamos alterando o futuro das instituições arquivísticas, da própria formação de futuros arquivistas. Então a gente está trabalhando numa fase que dificilmente eles vão esquecer, aquilo vai ficar guardado lá na memória, no subconsciente dessas crianças. Então, isso é fundamental. E ela vai ter um efeito muito positivo no futuro (informação verbal) ${ }^{51}$.

Então assim, um trabalho que a museologia faz que eu acho estupendo são as exposições e tudo mais. Arquivo faz pouca exposição, arquivo faz pouca divulgação do que tem. Um outro trabalho que eu acho excelente das bibliotecas: toda e qualquer biblioteca geralmente, quando recebe novas coleções, novos livros, novos periódicos, o que seja, tem lá um alerta 'recebemos tais e tais'. O arquivo não tem nada, você recebe por transferência, o usuário continua sem saber o que têm, o que foi acrescido naquele ano, o que foi desclassificado (informação verbal) ${ }^{52}$.

Acho que num primeiro momento ele conseguir manter os documentos organizados e disponibilizar o acesso já é uma grande coisa. E, de repente, se ele trabalha em instituição arquivística, pensar em promover ação cultural ou ações culturais que possam trazer o usuário para o arquivo de uma maneira lúdica, de uma maneira criativa, e aí sim ensinar e mostrar o 
potencial que o arquivo, que o documento de arquivo tem na vida desse cidadão (informação verbal) ${ }^{53}$.

E um entrevistado não apontou de forma precisa quais ações poderiam ser feitas, e atribui a distância ou ausência do cidadão no arquivos à questões culturais:

Que ações a gente pode fazer? As ações que a gente pode fazer já tem feito. [...] Mas só que tem uma questão, que volta àquilo que já te falei, é uma questão cultura mesmo. [...] Porque a Globo não se interessa em pôr um arquivista, um bibliotecário, como personagem principal de uma novela? Já que o povo adora novela, já que $80 \%$ da população assiste novela, quem sabe seria uma forma. Mas daí eu vou te falar 'essa seria uma ação'? Como que a gente vai fazer valorizar uma profissão que tradicionalmente ninguém sabe que existe? É uma coisa muito tenebrosa, sabe? (informação verbal) ${ }^{54}$.

Nesta categoria, sete, dos oito entrevistados apontaram ações significativas para que o arquivo consiga alcançar o seu usuário potencial, e de certa forma melhorar os serviços para os usuários reais. Muito se falou ao longo deste trabalho sobre as dificuldades de acesso, a responsabilidade do Estado e dos próprios profissionais. Claro, que ter uma legislação favorável ao acesso é essencial, e ter bons investimento para que se possa criar um ambiente estruturado para oferecer os melhores serviços aos usuários também ajuda bastante. Mas, destaca-se aqui neste trabalho, de forma especial, a parcela de responsabilidade do profissional e das instituições que formam esses profissionais.

A LAI, por exemplo, chama os profissionais que atuam nos arquivos, para trabalharem como mediadores da informação, tendo inclusive a responsabilidade de levar ao cidadão até uma informação que ele precise, mas desconhece que seja de seu interesse. E além de levar essa informação de uso potencial, deve garantir que ela seja de fácil compreensão tendo a responsabilidade em "traduzir" a informação para uma linguagem mais acessível ao seu usuário.

Em seus relatos, sete entrevistados apontaram que o ideal para se alcançar o usuário potencial, seria iniciar um trabalho nas escolas, desde os primeiros anos escolares, para formar indivíduos que no futuro tornem-se cidadão totalmente familiarizados com os arquivos, conscientes de seu acervo, de seus serviços, e com habilidades de fazer suas próprias escolhas. Um dos entrevistados, até associa essa iniciativa com o trabalho feito em muitas bibliotecas, um trabalho de desenvolvimento de competências e habilidades informacionais. É uma solução bastante interessante visto que objetiva por um trabalho contínuo com o indivíduo, inserindo a informação e o arquivo em sua vida de uma forma bastante natural.

Os serviços de alerta também foram levantados por um entrevistado, sugerindo o envio de mensagens para informar os novos documentos do arquivo, ou até mesmo para chamar a atenção para o acervo que a instituição já possui. Seria interessante também fazer-se o uso 
dos Serviço de DSI (Disseminação Seletiva da Informação), que tem o objetivo de enviar as informações de acordo com o perfil de interesse de cada usuário. Em casos onde o usuário esteja pesquisando a fundo sobre um tema, isso facilitaria muito no momento da busca, porque já teria em mente o que buscar, e economizaria tempo se debruçando por vezes sobre uma massa documental muito extensa.

Um entrevistado também destacou as exposições como forma de divulgação, da mesma maneira como é feita nos museus, só que destacando neste caso, os documentos, fotos, vídeos disponíveis, de uma maneira bem criativa e de fácil acesso aos usuários. Esse tipo de ação talvez seja a mais fácil de implantar, por ter um custo baixo e pelo fato de chegar ao usuário de uma forma imediata, assim que ele entra na instituição já se depara com as possibilidades a serem oferecidas, e para crianças nos primeiro anos escolares seja uma linguagem fácil de ser absorvida. Mas não basta apenas expor, faz-se necessária a presença de um profissional conhecedor do acervo para orientar os usuários. Independente da ação, a presença, a intervenção do arquivista é indispensável.

Essas ações relatadas pelos entrevistados já faziam parte de uma agenda de pesquisa na área desde a década de 1980, com os estudos para garantir maior acesso aos documentos arquivísticos, por meio da eliminação de barreiras de Duchein (1983), criação de instrumentos de recuperação (DOOLEY, 1992 apud ARAÚJO, 2013) e maior conhecimento dos interesses dos públicos (PUGH, 1982 apud ARAÚJO, 2013). Jimerson (1989) também alerta para a necessidade de a partir dos resultados desses estudos possa interferir nas ações e práticas arquivísticas.

3. Uso e usuários de arquivos:

Essa categoria engloba a visão dos entrevistados a respeito das diferenças entre o uso e usuários da informação arquivística.

Os oito entrevistados acreditam que existe sim, diferença entre os usuários de um arquivo, o uso que fazem da informação e que cada um tem uma necessidade diferente que deverá ser atendida pelo arquivo:

[...] O usuário, sim, especialmente no arquivo corrente e intermediário, que a gente tem o administrador como principal usuário. Então chega no arquivo permanente, o administrador continua sendo usuário, mas o usuário externo está mais presente. Não quer dizer que o usuário externo não esteja presente no arquivo corrente intermediário. Pela lei de acesso, hoje qualquer um pode ter acesso aos documentos, em qualquer idade. Mas, preferencialmente e classicamente nos arquivos permanentes é que a gente tem o usuário externo como mais presente-o cidadão e o pesquisador (informação verbal) ${ }^{55}$

O usuário no arquivo corrente é um usuário administrativo, é o administrador que está trabalhando ali no dia a dia. Então é um profissional técnico que precisa de informações muito específicas, muito dirigidas, não tem tempo, é um cara que não vai pesquisar, ele quer dados bastante específicos, não tem tempo pra respostas nem ambíguas nem muito inespecíficas, é um perfil bem 
administrados. No arquivo intermediário, você começa a ter um pouco mais uma coisa da pesquisa, mas eu acho que ainda na administração: você vai fazer pesquisa, você tem um pouco mais de tempo, você olha (informação verbal) $^{56}$.

Em se tratando de usuário, a primeira coisa que a gente tem de ver é se são usuários internos e usuários externos. São duas coisas diferentes, apesar de que em alguns momentos elas se misturam. Em relação às 3 , os arquivos correntes são mais usados por usuários internos da instituição, que estiveram envolvidos até mesmo na criação desses documentos. Os arquivos permanentes já são mais para usuários externos-historiadores, pesquisadores e tal. E tem uma figura que pode se confundir nesse momento, porque ou é interno ou é externo. Por exemplo, o arquivo público do Estado tem um funcionário interno, que faz a pesquisa para o usuário externo, que vai digitalizar e enviar para o usuário-virtual, a distância e por aí vai. Então existe uma diferença sim: de acordo com a idade dos arquivos, vai ter um usuário com características próprias (informação verbal) ${ }^{57}$.

E entre esses entrevistados, houve um que além de também reconhecer as diferenças entre os usuários e uso da informação arquivística, ainda destacou que a Lei de Acesso à Informação faz com que os "limites" entre cada um se confundam às vezes:

"Bom, a diferença... com alei de acesso à informação, isso ficou um pouco mais complexo até: categorizar esses usuários em suas respectivas fases. A diferença basicamente parte da questão primordial que são os valores dessas fases" (informação verbal) $)^{58}$.

Os entrevistados relataram que existe sim diferenças entre os usuários de arquivos de acordo com sua idade: corrente, intermediário e permanente. Ávila e Souza (2011) apontam que na literatura arquivística classifica três grupos distintos de potenciais usos dos registros orgânicos: a) acadêmico-científico; b) administrativo; e c) popular.

O usuário acadêmico-científico é sempre considerado aquele que possui uma grande habilidade e já está bastante familiarizado com os serviços e instrumentos do arquivo; o administrativo é o funcionário da instituição que necessita de informações rápidas e precisas para a resolução de problemas; e o popular ou cidadão comum é aquele que representa a maior parte da população, que desconhece quase que totalmente os serviços e instrumentos de busca dos arquivos, frequentando o arquivo de forma esporádica e por muitas vezes movido por uma curiosidade.

Essa definições que classificam os usuários de acordo com o seu nível de desenvoltura dentro dos arquivos, perde o sentido quando lembramos que a responsabilidade de tornar as ferramentas mais amigáveis, e que a tarefa de busca seja feita de uma maneira intuitiva e natural, possibilitando ao maior número possível de usuários uma boa compreensão é do arquivista. É claro que um pesquisador terá sim maior familiaridade, visto que frequenta o 
arquivo com uma frequência maior. De novo cai-se aqui na questão de que se o usuário sente dificuldade, talvez não seja só pela sua baixa frequência nesse tipo de instituição, talvez o sistema não tenha sido planejado pra ele. O equívoco acontece pois, por inúmeras vezes o arquivista realiza a maior parte das buscas, o que faz dele um usuário também, mas conforme um dos entrevistados também relatou, sempre haverá um usuário externo, e o sistema deve estar preparado para recebê-lo.

Sete entrevistados reconhecem a diferença entre os usuários, e que deve sim haver um planejamento para diminuir as dificuldades encontradas no momento do acesso, seja ele um administrador, um pesquisador, estudante ou cidadão comum. Destacaram também que a atenção deve ser maior nos arquivos permanentes, que é onde se concentra um público maior de usuários externos. Sobre os arquivos permanentes, Jardim (1999) já alertava para essa tendência em privilegiar o usuário do arquivo permanente, sem contemplar as especificidades que envolvem os usos e usuários das demais fases do ciclo vital arquivístico.

Um entrevistado fez uma declarou que após a LAl, tornou-se mais difícil classificar os usuários de acordo com cada fase do arquivo, visto que com a lei, o acesso foi ampliado e talvez surjam novos tipos de usuários. Fato que também já foi abordado por Jardim e Fonseca (2004), que diante da emergência de práticas inéditas de produção, transferência e uso da informação abre possibilidades ilimitadas para seu uso e oferta, envolvendo um conjunto cada vez mais amplo e "anônimo" de indivíduos.

4. Usuário Remoto

Essa categoria reúne a opinião dos entrevistados sobre as mudanças que as TICs (Tecnologias de Informação e Comunicação) tem feito na arquivologia, de forma especial nos serviços dos arquivos, com a chegada de um novo usuário, o usuário remoto.

Todos os entrevistados afirmam que essas novas tecnologias trazem sim mudanças para a arquivologia, que a mudança é essencial para acompanhar novas formas de ter acesso à informação:

Uma mudança drástica. Mudanças drásticas em todos os sentidos. Hoje, a preocupação não é apenas aquele usuário real, aquele que a interface é feita pessoalmente nas instituições arquivísticas, no serviço de arquivo. Até porque hoje a sociedade-eu, você, todo mundo-a gente quer cada vez... exemplo é essa conversa, que é via Skype... então a gente usa todos esses recursos tecnológicos pra facilitar a vida, pra minimizar tempo, minimizar esforço. Então, o usuário vem já com essa demanda, então o arquivo precisa responder a essa demanda. O usuário pode estar em qualquer lugar do mundo e o arquivo tem que dar conta (informação verbal) ${ }^{59}$.

Eu acho que tem várias mudanças, porque hoje você vai ter cada vez menos usuário fisicamente no seu arquivo. Hoje a gente fala que são arquivos sem muro. Acho que cada vez mais o profissional de arquivo tem que estar preparado pra esse atendimento remoto, já se anteceder e pensar em 


\begin{abstract}
divulgar os documentos na internet, guias de pesquisa, e oferecer instrumentos para quem vai ser o seu usuário. $E$ pra que isso aconteça precisa saber quem são os seus usuários (informação verbal) ${ }^{60}$.
\end{abstract}

E dois entrevistados além de reconhecer as mudanças causadas pela TIC's e o surgimentos de um novo tipo de usuário com necessidades específicas, também destacaram o fato de a maioria dessas ferramentas tecnológicas ainda não terem alcançado o cidadão comum:

\begin{abstract}
Nós não podemos fugir disso, né? As tecnologias estão aí batendo nas nossas portas, nós não podemos fechá-las. E esse usuário tem importância sim, só que pelo menos pra realidade daqui, há necessidade de abarcar esses usuários comuns, eu diria assim, aqueles usuários mais comuns, porque eu acho que se nós não dermos conta desse usuário, nós não vamos dar conta desses outros. Eu acho que seria um processo (informação verbal) ${ }^{61}$.
\end{abstract}

"Então, pra área de Arquivologia, eu acho que isso trouxe um avanço significativo no que diz respeito à comunicação da informação. [...]. Se bem que eu acho que ainda o cidadão comum ainda não incorporou essa forma de pesquisa remota. Usa pouco ainda." (informação verbal) $^{62}$

Os avanços das tecnologias de informação e comunicação tem impulsionado mudanças em unidades de informação de modo geral já há algum tempo. Várias iniciativas tem sido realizadas procurando aproveitar ao máximo as potencialidades da Web, como por exemplo os repositórios digitais. Este tipo de iniciativa, que foi possibilitado através principalmente da internet, transformou de forma drástica a comunicação científica. A internet possibilitou ainda a parceria entre pessoas que jamais se encontraram, mas hoje podem se comunicar em tempo real de vários lugares do mundo.

O impacto dessas novas tecnologias também recai sobre os acervos de unidades de informação. As bibliotecas por exemplo tiveram que repensar a política de organização de suas coleções, considerando agora como alternativa, adquirir publicações digitais, que podem ser em muitos casos mais barata e ocupam menos espaço. Os livros digitais surgem buscando colocar ao alcance do leitor clássicos da literatura e as últimas novidades lançadas no mundo. A informação parece estar cada vez mais ao alcance de todos. Nos arquivos, essas novas tecnologias também trouxeram impactos. Jardim (1999) aponta alguns fatores importantes: o conceito de "lugar" torna-se secundário para o profissional da informação e para os usuários; onde a informação se encontra não é o mais importante e sim o acesso à informação; e a 
ênfase na gestão da informação desloca-se do acervo para o acesso, do estoque para o fluxo da informação, dos sistemas para as redes

Todos os entrevistados foram unânimes em afirmar que não se pode mais ignorar essas tecnologias e que elas devem ser absorvidas nos serviços prestados ao usuários. Esse novo usuário, o usuário remoto, tem ao seu alcance uma quantidade incalculável de informações e pode se comunicar a qualquer tempo com qualquer lugar. As potencialidades são infinitas, mas como usá-las em novos serviços nos arquivos? Os serviços de referência virtual são exemplo disso, utilizando desde as formas mais simples de comunicação virtual, como os e-mails, até os serviços de atendimento e orientação ao usuário em tempo real através de chats, Skype e outros aplicativos.

Além disso tem uma questão importante que é a digitalização de documentos dos arquivos para serem disponibilizados na Web. Muitas instituições já realizam este serviço, uma maneira mais fácil para que o usuário tenha acesso ao acervo. É claro, que nem todo documento poderá disponibilizado devido a sua classificação ou devido ao seu estado de conservação. Mas se o documento estiver em estado de ser digitalizado, isso pode evitar que seja danificado, visto que tendo sua versão digital, diminuirá o seu manuseio evitando certos danos.

Dois entrevistados ainda destacaram o fato de que o cidadão comum em sua grande maioria ainda não incorporou o uso dessas novas tecnologias. Por esse motivo, todas essas ferramentas disponíveis nos dá a sensação de que a informação está ao alcance de todos, mas é só uma falsa aparência. O que o profissional deve compreender é que ele deve sim absorver as novas tecnologias, mas deve também continuar se preocupando com os serviços presencias, com a elaboração de boas ferramentas manuais, ele deve ser capaz de atender a todos, seja o usuário remoto, seja o usuário presencial. As velhas e as novas tecnologias por muito tempo ainda vão coexistir exigindo do profissional flexibilidade para trabalhar em todos os contextos.

5. Desenvolvimento dos Estudos de Usuários na Arquivologia

Sete entrevistados falaram sobre o desenvolvimentos da temática dos Estudos de Usuários na Arquivologia nos últimos anos. Desses, cinco acham que o desenvolvimento desses estudos ainda encontram-se em um estado incipiente, e atribuem isso a preocupação apenas com a parte técnica dos arquivos:

Falta de experiência. Eu acho que nós somos uma ciência muito mais jovem do que, por exemplo, a Biblioteconomia, e a gente ainda não está acostumado a fazer esse tipo de pergunta. Isso é uma coisa. A segunda coisa, eu vou voltar à lei de acesso à informação, da cultura do sigilo da informação: os documentos de arquivo eram dificilmente consultados, eram pouco acessíveis. Então, se não tem acesso, como é que você vai estudar um usuário que não existe. Você tem poucos usuários, então você vai estudar quem? Então eu acho que tem as duas coisas. Mas eu acho que é mais por essa questão assim: nós não tivemos tanto tempo pra fazer pesquisas 
consistentes, e desenvolver pesquisas técnicas voltadas a questões específicas dos arquivos, então a gente usa ainda muito a matriz teórica da Biblioteconomia pra esses estudos. Então eu acho que com o tempo isso vai se expandindo. E a experiência também vai trazendo novas pesquisas e vai reajustando o processo como um todo (informação verbal) ${ }^{63}$.

Olha, é uma discussão um pouco ainda inicial. Por que? Pelo menos assim, o quê que eu pude perceber? Na própria docência tem alguns colegas da área que não identificam o usuário como uma área de exploração, de potência pra nós avançarmos na própria graduação, enquanto disciplina. Isso eu tento demonstrar que é um grande equívoco, porque é aquilo que eu falei inicialmente, o usuário está presente, ele deve ser um dos nossos enfoques de estudo. Então eu percebo que ainda não se tem a visão pra estudar usuário como se pretendia (informação verbal) ${ }^{64}$.

O quê que acontece? Por muito tempo a Arquivologia clássica - se assim posso aditivá-la - ficou preocupada com as questões técnicas. Então a preocupação maior é a classificação, a avaliação, o instrumento de pesquisa sem pensar na interface que faz com o usuário. Então essas preocupações sobressaíram nas pesquisas e nas preocupações dos pesquisadores e dos profissionais. E isso digamos que retardou a pesquisa em Estudo de Usuário. Então, o usuário sempre ficou à margem das discussões arquivísticas, porque sempre quem esteve em evidência neste contexto foram os processamentos técnicos, a criação dos instrumentos (informação verbal) ${ }^{65}$.

Um entrevistado, diz que não acredita que a temática dos Estudos de Usuários esteja em um estado incipiente, porém afirma ao final que é preciso ainda avançar:

[...] eu não vejo esse estado incipiente não da disciplina. Eu acho que a temática... na verdade, eu nem gosto mais de usar esse termo 'estudo de usuário'. Na verdade continua sendo um estudo de usuário, mas a gente tem que se voltar para o indivíduo, para o ser. Esse é o progresso da nossa sociedade, a gente tem que passar a ver a pessoa e não o... quando eu falo 'estudo de usuário', usuário de que? Usuário do sistema, usuário do documento. Hoje em dia é usuário da informação na verdade. Informação é algo que todo ser humano precisa. Então, eu gosto de chamar de comportamento informacional. Eu não gosto de chamar de estudo de usuário não. Na verdade é um estudo de usuário, mas quando você fala em comportamento informacional, você já desloca a temática para o indivíduo. Eu acho que só assim a gente realmente vai dar valor e vai fazer a disciplina crescer a sua relevância dentro do curso (informação verbal) ${ }^{66}$.

Outro entrevistado diz que o estágio de desenvolvimento da temática "Estudos de Usuários na Arquivologia vai depender da postura de cada profissional, mas não sabe precisar se este fator é um impeditivo do avanço da temática na área:

[...], eu acho que depende muito da postura do arquivista e também do pesquisador em arquivos. Tem arquivista que tem uma postura passiva, que acha que só vai mexer no documento quando ele entrar no arquivo. Tem arquivista que sabe que hoje em dia a gente trabalha esse documento lá 


\begin{abstract}
quando ele está sendo produzido, até antes, na ideia da gênese documental como fala a Profa. Heloisa Bellotto. Então eu acho que isso é bem relativo. Tem instituição que não trabalha com essa forma e tem instituição que pensa o arquivista só como o custodiador, o gestor da custódia desse documento. Então depende. Depende de como que o arquivista é formado, depende de qual a postura dele no mercado de trabalho. Eu acho que isso... não sei se isso atrasou o desenvolvimento teórico da área. Até porque durante muito tempo se pensou dessa forma. Não sei. Não sei. Nunca pensei. Não sei te responder de pronto (informação verbal) ${ }^{67}$.
\end{abstract}

O surgimento da discussão sobre estudos de usuários na Arquivologia se deu de maneira mais forte na década de 1960, mas a partir da década de 1980 é que surgem basicamente duas linhas de pesquisa: surgem os primeiros estudos procurando garantir 0 acesso por meio da eliminação de barreiras, e outra preocupada com a criação de novos instrumentos de recuperação da informação para atender os interesses públicos e por outro lado buscava uma reorientação da prática profissional com ações voltadas aos usuários através das práticas arquivísticas, conforme apontado por Gonzalez Teruel (2005).

Ao final do Congresso Internacional de Arquivos de 1996, Ketellar faz uma declaração em seu discurso final onde demonstra perfeitamente a falta de um olhar mais apurado para os usuários de arquivos, e demonstrou também ainda estar esperançoso que ao final daquele congresso, daquele chamado de um profissional ciente de sua responsabilidade social, os arquivos pudessem enfim abrir suas portas e janelas para a sociedade.

Um dos entrevistados remete-se à situação dos arquivos há algumas décadas atrás e questiona de que maneira o arquivo poderia se preocupar com o usuário em uma época que ele nem existia, em uma época em que não haviam leis como hoje, onde a informação é direito básico de todo cidadão. Por este motivo, não pode-se dizer que a Arquivologia encontra-se em uma situação de "atraso" de desenvolvimento de estudos voltados para o usuário. $\mathrm{Na}$ verdade faz pouco tempo que ele despertou para isso, e desde então, cada vez de maneira mais profunda, as discussões vem aumentado.

Cinco entrevistados consideraram que os estudos de usuários na Arquivologia se encontram em um estado incipiente ainda, mas é apenas uma questão de tempo para que os Arquivos encontrem suas metodologias específicas e seu jeito próprio de lidar com os usuários. Outro entrevistado ainda considerou que a responsabilidade desse pouco desenvolvimento é dos docentes das universidades pois não identificaram ainda o usuário como uma área de exploração, o que de certa forma interfere no tipo de profissionais que estão formando. E esses cinco entrevistados também destacaram que os Arquivos ainda estão focados nos documentos, e menos nas pessoas. 
Um entrevistado apenas não considera que os estudos de usuários na Arquivologia estejam em estado incipiente, no entanto, destaca que apesar do desenvolvimento conquistado aqui, ainda tem muito o que avançar.

Em um dos primeiros textos tratando sobre a necessidade de se abrir agendas de investigação sobre usuários de arquivos no Brasil, o Professor José Maria Jardim destacou alguns fatores que provocavam uma necessidade de mudança no foco das práticas dos profissionais, destacando-se aqui o fato de que instituições como arquivos, bibliotecas e centros de documentação adquirem novas funções e com os avanços das novas tecnologias, os usuários produzem novas demandas para os arquivos. A combinação entre os avanços na legislação do país com os avanços tecnológico, sem dúvida foram os principais motivadores de uma mudança de foco, passando do documento para o acesso.

Um entrevistado apontou a postura de cada profissional como um fator importante para o desenvolvimento da temática, apesar de não saber dizer se foi a falta dessa postura que impediu os avanços da temática na área. Em cada entrevistado, o que pode-se perceber é um complemento em cada resposta, pois a questão do desenvolvimento de uma temática depende de vários fatores: depende de uma formação profissional que possibilite a mudança de suas práticas, sendo importante então as ações das universidades, e ainda que essas ações sejam efetivas, torna-se necessário uma legislação favorável, investimentos na organização dos arquivos, e a disponibilização de ferramentas tecnológicas na elaboração dos serviços.

6. Biblioteconomia como referência:

Quatro entrevistados apontaram a Biblioteconomia como referência no desenvolvimento de estudo de usuários para a Arquivologia:

"[...] A partir do momento que que você tem disciplinas voltadas em Estudos de Usuários, tem toda uma metodologia que o pessoal da Biblioteconomia já sabe usar e que aí a gente começa a aprender agora (informação verbal) ${ }^{68}$; "[...] E o usuário na fase permanente, aí sim eu penso que a gente pode entrar numa linha de Estudos de Usuários muito parecida com a Biblioteconomia" (informação verbal)69; "Eu acho que você deve ter observado que a Biblioteconomia está quilômetros caminhando na frente, se comparado ao Estudos de Usuário. Nós temos muita literatura na área de Biblioteconomia e pouca literatura na área de Arquivologia pra estudar os usuários" (informação verbal) ${ }^{70}$; "E aí eu comecei a oferecer uma disciplina optativa chamada de Estudo de Usuário, aos moldes da Biblioteconomia, só que com aplicação para Arquivologia" (informação verbal) ${ }^{71}$. 
Quatro entrevistados relataram em seu discurso a associação imediata entre o tema "Estudos de Usuários" e Biblioteconomia. Segundo Schellenberg os arquivistas tem muito a aprender da biblioteconomia, visto que ela comunga do mesmo objeto de estudo que a arquivologia, isto é, a informação. Mas é evidente que cada um tem uma identidade, que agrupa seus princípios, métodos e sua terminologia. Os primeiro estudos surgiram na década de 1930 em bibliotecas, por meio de estudos da comunidade.

Apenas na década de 1960 é que as ciências sociais aparecem nos Estudos de Usuários, como objeto de investigação, por meio de uma iniciativa de investigação do comportamento informacional de cientistas sociais, que até então eram ignorados por serem considerados um grupo que utilizava uma massa menor de informação, o que hoje sabemos que não verdade. Essa iniciativa resultou em uma contribuição para os estudos de usuários, levando a estudos com uma análise qualitativa, utilizando técnicas e referências da Psicologia e da Administração a fim de alcançar uma maior compreensão do indivíduo, passando de um estudo centrado no sistema, para um estudo focado no usuário.

Os Estudos de Usuários possuem um caráter interdisciplinar, não apenas no seu arcabouço teórico, mas na sua aplicabilidade. Isso fica comprovado desde as primeiras investigações realizadas por profissionais das áreas das ciências experimentais e tecnologia, e depois recebendo contribuições da Sociologia e da Psicologia, o que segundo Menzel (1966) trouxe mais qualidade aos trabalhos. No entanto, Lipetz (1970) afirmou que os avanços ocorridos com a incorporação destas disciplinas ainda se apresentavam em um estado incipiente, sendo necessário um aprofundamento na elaboração dos métodos. O que hoje já pode ser detectado por meio dos avanços dos estudos sobre comportamento informacional, que não se limitam apenas em unidades de informação (arquivos, bibliotecas e museus), sendo possível de serem realizados em uma imensa diversidade de ambientes.

Um entrevistado fala sobre os avanços conquistados pela Biblioteconomia na aplicação dos métodos e técnicas de investigação sobre Estudos de Usuários. É importante também observar os fatores históricos que refletiram em um estado incipiente sobre essa temática nos arquivos. Costa (2011) enfatizou essa questão lembrando que até a primeira metade do século XX não se observam mudanças substantiva com relação à abertura dos arquivos ao público. O direito à informação só foi cogitado em 1948, com a publicação da Declaração Universal dos Direitos do Homem pela Assembleia Geral das Nações Unidas. Por esta razão é importante olhar com bastante cuidado essa questão, visto que cada ciência avança em seu próprio ritmo. É importante lembrar aqui o caso brasileiro, que viveu vinte e um anos de ditadura, onde o acesso à informação era apenas instrumento e privilégio do Estado. É óbvio que em um contexto assim, não havia como avançar o pensamento, visto que todo pensamento, principalmente em ambientes educacionais eram direcionados de acordo 
com interesses de uma minoria dominante, que não via de forma interessante a abertura e o acesso aos arquivos.

Com o fim da Ditadura em 1985, o que observa-se é um avanço em garantir a informação como direito básico, e atualmente o país já possui uma legislação favorável, considerada uma das melhores do mundo. A Lei de Acesso à Informação é de 2011, e o tempo ainda é curto para pontuar sobre as suas contribuições de forma mais concreta.

Outro entrevistado relata que no arquivo permanente pode-se utilizar de métodos adotados em bibliotecas. Talvez seja realmente possível no que diz respeito a tentar traçar o perfil dos usuários, criar um serviço de referência para auxiliar na pesquisa, mas em relação a criação e treinamento das ferramentas de busca, faz-se necessário métodos capazes de atender as especificidades de cada usuário de arquivo.

7. Contribuições dos Estudos de Usuários para a Arquivologia:

Todos os entrevistados fizeram considerações sobre as contribuições que os estudos de usuários tem ou podem ter na arquivologia como auxílio aos profissionais dentro dos arquivos:

Olha, eu vejo a disciplina de Estudo de Usuário dentro do curso de Arquivologia como uma luz, uma luz no sentido de que 'pra quê que eu vou fazer todas as atividades técnicas com o documento, seja ele suporte papel, suporte digital, se não for para usar?'. Quem que usa? O usuário, o indivíduo, seja dentro de uma empresa, uma indústria, um comércio, ou seja dentro de um órgão público. Então, essa disciplina, a importância dela é chamar atenção assim 'olha, os arquivos hoje existem para o usuário' - quer dizer, sempre existiram, mas houve época que os arquivos eram escondidos a 7 chaves, não é? Mas, enfim... essa disciplina, eu vejo a importância dela assim: pra abrir mesmo a cabeça, pra ampliar a formação (informação verbal) ${ }^{72}$.

Eu digo que o Estudo de Usuário é o medidor. Nós prestamos um serviço, então o Estudo de Usuário pode ser estratégico para a instituição, porque ele vai medir o grau de satisfação do nosso cliente com o nosso serviço. E o Estudo de Usuário dentro da Arquivologia deve ter esse papel estratégico. Ou seja, dentro do Estudo de Usuário você pode analisar, por exemplo, a demanda de informação, a necessidade do usuário, o grau de satisfação, o comportamento do usuário. Então, todas essas possibilidades vai somar no planejamento estratégico da instituição ou do serviço. Então, o Estudo de Usuário é importantíssimo no contexto da Arquivologia (informação verbal) ${ }^{73}$.

"Eu sou uma defensora de que a gente deveria ter sim uma disciplina voltada para o usuário. São 2 questões: essa questão do arquivista, que é outro tema, mas é só pra você pontuar, como é que você faz um curso, desenha um curso de formação, e você não tem uma disciplina que comente sobre a própria ação do profissional? Você só ensina ele a fazer 'você vai fazer isso, fazer aquilo'. E a experiência que eu tive nessas 2 disciplinas...eu peguei alunos formando que falaram 'professora, eu nunca tinha me dado conta da nossa ação enquanto profissional'. Porque a pessoa, desde o início, desde $01^{\circ}$ semestre, é plano e é tabela, é plano e é tabela, que são os instrumentos básicos. E a pessoa sai dali, se ela não conseguiu entender sobre 
classificação e tudo, vai ser talvez um profissional médio, vai estar um pouco à margem do mercado de trabalho. Então assim, essas questões trazem um pouco da ansiedade do profissional em saber 'olha, você vai trabalhar com informação principalmente pra você difundir', e aí eu coloco 'difundir pra quem? ', para o usuário, é ele que está do outro lado. Eu sempre comento 'a gente tem um balcão, nós estamos do lado de cá e o usuário está do outro lado do balcão, só que de certa forma em alguns momentos também a gente tem de ir para o outro lado e pensar, como é que esse usuário pode estar vendo a instituição? Nós estamos realmente atendendo? Está havendo essa reciprocidade? Nós não temos que ser esse elemento, esse fator de ligação entre a informação e o usuário? Nós não temos que ser essa ponte, o arquivista? Nós estamos realmente fazendo esse elo? (informação verbal) ${ }^{74}$.

\section{Bibliografia para Estudos de Usuários:}

Em relação à bibliografia utilizada, voltada para os estudos de usuários, os entrevistados apontaram uma dificuldade em encontrar literatura voltada para usuários de arquivos:

Quando eu comecei a ministrar a disciplina, em 2006, tinha um único texto que era específico da Arquivologia... O estado da arte...Nossa! Aquele texto do José Maria Jardim, eu trabalhava assim... eu bebia ele, fazia os alunos beberem, ir atrás, porque é um texto muito rico, tem muita citação. Mas tinha só aquele específico mesmo. Aí com o passar do tempo foi surgindo. É lógico que ainda é incipiente a produção, mas se a gente for comparar, cresceu bastante, cresceu (informação verbal) ${ }^{75}$

Não se encontra na literatura hoje publicada muitos estudos de casos ou vários artigos discutindo Estudo de Usuário de Arquivo especificamente. Então, na maioria das vezes, eu pego um artigo que às vezes até trata de um outro material, de biblioteca, e a gente tira elementos pra trazer pra realidade arquivística (informação verbal) ${ }^{76}$

"Essa é uma grande dificuldade. Tem um texto da Rita Dolores, muito antigo em espanhol que eu utilizei voltado pra questão de usuário e a pouca metodologia da pesquisa, de como você pode investigar, são trabalhos de bibliotecários, inclusive de professores daqui, que ministravam essas disciplinas. Agora, não existe um livro que enfoque essencialmente a questão do usuário de Arquivologia, de Arquivos. Não existe (informação verbal) ${ }^{77}$

Dois entrevistados apontaram de forma clara a utilização de textos de áreas correlatas para ministrar a disciplina de usuários durante o curso: "[...] um terço são textos teóricos da Biblioteconomia, um terço são textos teóricos de Arquivologia, e um terço ou um pouquinho mais são esses estudos de relato de experiência que são usados para trabalho" (informação verbal) ${ }^{78}$; "[...] é uma bibliografia que vem da Ciência da Informação" (informação verbal) ${ }^{79}$. E apenas um entrevistado não falou sobre o assunto. 
Um outro entrevistado ainda relatou durante a entrevista a necessidade de ter manuais de arquivologia com uma parte voltada exclusivamente para o usuário e explicou de que forma ele deveria ser elaborado:

[...] E aí ele estaria alocado nessa parte final da gestão de documentos, que é a possibilidade do acesso...divulgação e acesso. Eu entendo que o usuário, que a posição do tratamento dado ao usuário seria alguma coisa nesse sentido. Então, se eu tivesse que criar um manual... dando um exemplo, um manual de gestão documental da organização $X$, ou da entidade $X$, ou do órgão $X$, eu teria nesse manual de gestão documental toda a parte operacional de funcionamento rotineiro do arquivo - não necessariamente nessa ordem - mas como é que se faz uma recepção de documentos, como é que acontece transferência, recolhimento, quem é responsável por cada área, quem é responsável por cada atividade, as atribuições, responsabilidades, a divisão de áreas, a rotinas; teria os instrumentos de gestão documental propriamente ditos, a parte de... tabela de temporalidade, enfim, esses instrumentos técnicos mais específicos de gestão; e eu teria uma terceira parte que, por falta de nome melhor agora, eu estou chamando de difusão e acesso - vamos pôr o nome que o pessoal dos arquivos permanentes gosta de dar - que é exatamente isso: em que circunstância eu posso dar acesso aos meus documentos, quem é o meu usuário preferencial, quem é que vai chegar, quem é que chega normalmente ao meu arquivo, qual a qualificação desse usuário, o que esse usuário normalmente vai pedir ou vai precisar, o que eu posso ou não fornecer de informação, de documentos pra esse usuário. E aí, dentro disso, pra elaborar esse procedimento, você tem que primeiro conhecer o seu usuário. Então teria que ter um trabalho anterior de diagnóstico, tem que dar a ideia de planejamento estratégico das ações de um arquivo qualquer que seja ele. Então eu dividiria nessas 3 partes o manual de procedimentos, por exemplo, e essa coisa do acesso seria a parte voltada mesmo à divulgação, a possibilitar o uso efetivo de todo aquele sistema que você montou antes (informação verbal) ${ }^{80}$

A baixa produção de textos relacionados aos Estudos de Usuários na Arquivologia, é algo que também chamou atenção dos entrevistados, fato que já foi apontado por Jardim (1994). Cinco entrevistados relacionaram a baixa produtividade sobre o assunto ao estado incipiente de investigação sobre o tema. Um número muito reduzido de pesquisadores envolvido com essa temática pode também resultar em uma dificuldade em encontrar textos que possam ser utilizados nas disciplinas voltadas aos usuários nos cursos.

Há que se considerar também o passo mais importante está sendo dado pelos cursos, que é o reconhecimento e a inclusão de disciplinas de usuários em seus currículos. Outro ponto a ser considerado, que a maioria dos cursos ainda é recente, e mesmo os antigos, nos últimos anos vem passando por enormes transformações, a fim de adaptar-se as exigências do mundo atual. Colocar em pauta a discussão da temática nas universidades é um primeiro passo, que a longo prazo espera-se refletir em um aumento em sua agenda de investigação e consequentemente refletirá também em um aumento de bibliografia especializada na área. 
Tudo isso faz parte de um grande ciclo, que agora depende do tempo para começar a aparecer os avanços.

Um entrevistado relata que há 20 anos atrás havia apenas um texto que era sempre usado como norteador das discussões, de autoria do Professor José Maria Jardim, onde ela procurava aproveitar ao máximo o texto na disciplina que lecionava, inclusive verificando as referências do artigo a fim de "engrossar" seu referencial ao longo da disciplina, mas destaca também que a bibliografia na área aumenta constantemente.

Outro entrevistado explica que diante da dificuldade em encontrar material específico de usuários de arquivos, costumava adaptar relatos feitos em bibliotecas para a realidade da Arquivologia. O que de certa maneira pode ser realizado, devido à característica interdisciplinar dos Estudos de Usuários, o que permite que seus modelos e métodos possam se adaptar a vários tipos de ambientes.

Um entrevistado declara a ausência de um livro que trate especificamente sobre usuários de arquivos, o que obriga os professores a buscarem pequenos textos na literatura estrangeira para fomentar a discussão. A produção bibliográfica nacional em Arquivologia, reflete o pensamento e as preocupações dos profissionais até então, oferecendo uma literatura farta em gestão documental, mas sendo carente quando o assunto é acesso e usuários.

Um entrevistado relata que na disciplina de usuários que lecionou, procurou utilizar textos da Biblioteconomia, Arquivologia e procurou estimular os alunos a irem a campo para desenvolver nos arquivos seus relatos de experiência. Incentivar os alunos a esse tipo de investigação é uma boa alternativa quando não se tem uma quantidade tão grande de referencial que dê insumos para investigações mais profundas.

Outro entrevistado ainda relatou a necessidade da criação de manuais de Arquivologia que contenham um capítulo ou unidade, que poderia ser intitulada "Difusão e Acesso" que seria totalmente dedicado aos Estudos de Usuários, o que em sua opinião daria maior consistência e serviria de referência para todos os profissionais. Essa "ausência de manuais voltados para as necessidades informacionais e estudos de usuários, foi apontada também por Jardim e Fonseca (2004). Conforme já levantado em outro momento, a criação de um manual que demonstre essa preocupação com o usuário, significaria o marco histórico de uma nova fase nos arquivos. Dowle (1992) sugere que os arquivistas busquem nas Ciências Sociais e na teoria da informação os marcos conceituais e métodos para investigar os diversos aspectos da prática arquivística relacionadas aos usuários. 


\section{PERSPECTIVAS}

De acordo com a literatura apresentada sobre a temática dos estudos de usuários de arquivos e com os resultados obtidos a partir das entrevistas com professores e coordenadores dos cursos de arquivologia, é possível avaliar os avanços já alcançados e o que se espera a partir dessa pesquisa:

- Pesquisas sobre os estudos de usuários de arquivos ainda se encontram em um estado incipiente;

- A inserção das disciplinas com essa temática nos cursos podem contribuir de maneira significativa para o avanço dos estudos de usuários na arquivologia;

- O arquivista deve apresentar características de um bom gestor, mas deve também atuar como mediador da informação; 
- O arquivista é consciente da importância do acesso, porém suas práticas ainda estão mais voltadas para os documentos e para os sistemas;

- O estado tem parcela de responsabilidade nas dificuldades de acesso, mas é importante destacar que a compreensão das necessidades dos usuários é responsabilidade do arquivista;

- Ações de difusão e marketing nos arquivos podem contribuir para diminuir a invisibilidade dos arquivos diante da sociedade;

- Cada usuário apresenta uma necessidade, de acordo com cada tipo de arquivo. Apesar de uma preocupação das instituições em atender as determinações da LAI no que diz respeito aos arquivos correntes com o acesso à documentação comprobatória, o arquivista deve fortalecer ações para que os arquivos históricos sejam também acessados pelos cidadãos comuns e não apenas por pesquisadores.

- As novas tecnologias deverão ser incorporadas para o aperfeiçoamento dos serviços que já são oferecidos, mas não devem ser consideradas como único recurso para alcançar os usuários;

- Espera-se que este estudo possa possibilitar a inserção do usuário no processo de gestão documental;

- Os estudos de usuários podem dar ao profissional a dimensão da complexidade de cada usuário e ajudá-lo a compreender o sujeito inserido em diversos ambientes sociais.

- Os estudos de usuários podem contribuir para o desenvolvimento de ferramentas de busca mais eficientes e eficazes.

\section{CONSIDERAÇÕES FINAIS}

Todas as considerações levantadas até aqui tem o intuito de nos levar a refletir sobre os avanços no pensamento arquivístico em seu arcabouço teórico e prático em relação ao acesso. Partindo sobre a construção dos currículos dos cursos de nível superior, é evidente a necessidade de além de serem flexíveis, devem se manter constantemente atualizados, observando-se as demandas do mercado de trabalho. $O$ diálogo entre universidade e associações profissionais ainda estão em um processo de construção, e o seu fortalecimento depende das ações dos profissionais da área. Deve-se no âmbito acadêmico sempre se refletir, assim como já foi proposto nas teorias pós-críticas do currículo, sobre o privilégio de 
determinados grupos de disciplinas ou não. O currículo deve ser visto como reflexo das necessidades de uma sociedade e de seu contexto histórico. As deficiências na formação do arquivista no que diz respeito a preocupação com o usuário, conforme apontado por Souza (2011), a preocupação com o objeto físico da informação, o suporte, hoje é apenas parte de todo um processo de gestão documental, e não uma prioridade nos fazeres profissionais.

As pesquisas sobre os currículos dos cursos de arquivologia no país, desenvolvidos até o momento, demonstram que nos últimos vinte anos houve transformações significativas, apontando para um quadro de desenvolvimento bastante positivo. Essas transformações demonstram a mutabilidade do currículo, e que os profissionais e os pesquisadores estão cada dia mais envolvidos e atentos com as novas demandas sociais. Além do aumento do número de cursos, que é perceptível desde o trabalho pioneiro de Jardim (1995), onde existiam apenas quatro cursos, até o trabalho de Marques (2011), onde já são apresentados 15 cursos, e o trabalho mais recente de Arreguy, Negreiros e Silva (2013), onde são avaliados os 16 cursos oferecidos atualmente; é notório o avanço sobre a preocupação com a difusão da informação. No estudo de Marques (2011), apenas três universidades ofereciam disciplinas voltadas para estudos de usuários, hoje apenas uma universidade ainda não incluiu essa temática em sua matriz curricular.

O acesso sempre foi preocupação do arquivista, mas com um foco mais voltado para a elaboração de ferramentas e organização do acervo, do que propriamente com o usuário. Essa característica levantada por Jardim e Fonseca (2004), mostra-se em um cenário de imensas transformações. Se antes estes mesmos autores também detectaram uma baixa produtividade sobre o tema na área, hoje esses trabalhos estão sendo produzidos. A ausência de discussão sobre o usuário durante a graduação também está sendo contornada, o que refletirá em um aumento da bibliografia específica da área.

A função social do arquivista já está estabelecida desde a regularização da profissão em 1978. Além disso, várias associações profissionais em todo o mundo também reconhecem e estabelecem essa função como primordial no desenvolvimento de suas atividades. Essa pesquisa vem confirmar a sua importância como um transformador social, no momento que é capaz de levar ao cidadão comum, a informação que precisa, e também a consciência de que o arquivos são parte do processo da construção de uma memória coletiva.

As áreas de atuação profissional são amplas e em cada instituição, seja pública ou privada, seja em arquivos permanentes, correntes ou intermediários, o arquivista deve agir como um gestor da informação, preocupando-se em todo o processo com sua atividade fim principal: o acesso. É necessário destacar que a preocupação com a custódia, ou com o documento não significa excluir ou diminuir a preocupação com a difusão, na verdade um complementa o outro. 
No Brasil, a Lei de Acesso à Informação, não vem apenas consolidar direitos, mas oferece aos arquivos e principalmente ao profissionais, a oportunidade de divulgarem os serviços oferecidos, e de consolidarem o diálogo entre arquivo e sociedade, colocando o arquivo como instituição indispensável no estabelecimento de uma democracia plena.

As novas tecnologias não devem mais ser ignoradas, devem ser absorvidas pelas instituições a fim de dinamizar os serviços e criar outros capazes de atender o usuário remoto. O uso dessas tecnologias podem ajudar de maneira eficaz tanto na ampliação de possibilidades de acesso, quanto na preservação e conservação do acervo. O marketing, a organização de exposições são ações que podem auxiliar na difusão da informação, principalmente no alcance do usuário potencial.

Se há vinte anos trás, o cenário sobre o avanço dos estudos de usuários na arquivologia ainda se encontrava adormecido, hoje pode-se dizer que os arquivistas realizam todas as suas atividades para que as necessidades do usuário sejam atendidas. A compreensão do comportamento, dos processos cognitivos que envolvem uma busca de informação, são essenciais para a elaboração de políticas de acesso. A mediação da informação também é um termo que já faz parte do discurso arquivístico, possibilitando a criação de programas de treinamento capazes de atender as especificidades de cada usuário.

Diante disso, é inegável a contribuição dos métodos e técnicas dos estudos de usuários na formação do arquivista com um perfil mais dinâmico e envolvido com o meio onde atua. A aplicação desses métodos podem contribuir para a elaboração de ferramentas mais amigáveis, para o uso potencial e eficiente das novas tecnologias, para a divulgação dos acervos institucionais, para a ampliação das possibilidades de acesso, para o desenvolvimento de políticas de acesso, para a ampliação do conceito e dos tipos de usuários, para a criação de manuais específicos para atender as demandas dos usuários de arquivos nas suas três fases, e o desenvolvimento de um programa de treinamento do usuário. Esperase que este trabalho possa contribuir para o avanço de movimento que sai de um modelo de "'[...] arquivos direcionados para os arquivistas" para "arquivos direcionados para os usuários" (JARDIM; FONSECA, 2004).

\section{REFERÊNCIAS}

ALA. American Library Association. Presidential Committee on Information Literacy: Final Report. 1989. Disponível em: <http://www.ala.org/ala/mgrps/divs/acrl/ publications/whitepapers/presidential.cfm> Acesso em: 12 ago. 2010.

ALEGBELEYE, Gabriel. Designing the archival education curriculum: what experience from what experiences from what disciplines, why and how ? Archivum, Paris, CIA, 39: 284-296, 1994 apud BELLOTTO, Heloísa Liberalli. Os desafios da formação profissional dos modernos arquivistas. Cenário Arquivístico, Brasília, v. 1, p. 47-52, 2002. 
ARAÚJO, Carlos Alberto Ávila. A perspectiva de estudos sobre os sujeitos na Arquivologia, na Biblioteconomia e na Museologia. Revista da Faculdade de Biblioteconomia e documentaçãoda UFGRS. Porto Alegre, v. 19, n. 1, p. 213-238, jan./jun. 2013.

ARQUIVO NACIONAL (Brasil). Subsidios para um Dicionário Brasileiro de Terminologia Arquivistica. Rio de Janeiro, 2004. Disponível em:

<http://www.arquivonacional.gov.br/download/dic_term_arq.pdf>. Acesso em: 19 ago. 2014.

ASSOCIAÇÃO DE ARQUIVISTAS QUEBEQUENSES. Disponível em: <http://www.archivistes.qc.ca/>. Acesso em: 20 ago. 2014.

ÁVILA, Rodrigo Fortes de; SOUSA, Renato Tarciso Barbosa de. A aporia dos estudos de comportamento informacional na arquivística. Cenário Arquivístico, Brasília-DF, v. 4, n. 1, p. 41-53, jan./jun., 2011.

BASTOS, Aurélio Wander Chaves; ARAÚJO, Rosalina Corrêa de. A legislação e política de arquivos no Brasil. Acervo, Rio de Janeiro, v. 4/5, n. 2/1, p. 19-13, jul./dez., 1989 /jan./jun., 1990.

BATISTA, Carmem Lúcia. Mediação e apropriação: questões do direito de acesso à informação. In: MOURA, Maria Aparecida (Org.). A construção social do acesso Público à Informação no Brasil: contexto, historicidade e repercussões. Belo Horizonte: Editora UFMG, 2014

BELLOTTO, Heloísa Liberalli. A profissão e o ensino da arquivologia. Boletim do arquivo, São Paulo, v.1, n.1, p.11-18, 1992.

BELLOTTO, Heloísa Liberalli. Os desafios da formação profissional dos modernos arquivistas. Cenário Arquivístico, Brasília, v. 1, p. 47-52, 2002.

BELLOTTO, Heloísa Liberalli. Arquivos Permanentes: tratamento documental. 2. ed. Rio de Janeiro: Editora da Fundação Getúlio Vargas, 2004. v. I.

BLAIS, Gabrielle. Accès aux documents d'archives: etat dês lieux. Etude RAMP. Paris Unesco, 1995 apud ÁVILA, Rodrigo Fortes de; SOUSA, Renato Tarciso Barbosa de. A aporia dos estudos de comportamento informacional na arquivística. Cenário Arquivístico, Brasília-DF, v. 4, n. 1, p. 41-53, jan./jun., 2011.

BORRÁS, Joaquim. Las relaciones entre archiveros y produtores de documentos. Archivo de La Universidad Pompeu Fabra, Espanã, Marzo, 2001. Disponível em:

<http://eprints.rclis.org/bitstream/10760/5576/1/A7-01.pdf>. Acesso em: 15 ago. 2014.

BOTTINO, Mariza. A interdisciplinaridade na graduação em arquivologia. In: JARDIM, José Maria; FONSECA, Maria Odila (org.). A formação do arquivista no Brasil. Rio de Janeiro: EdUFF, 1995

BRASIL. Constituição (1988). Constituição da República Federativa do Brasil. Brasília: DF, Senado, 1988.

BRASIL. Lei no 6.546 de 4 de julho de 1978. Dispõe sobre a regulamentação das profissões de Arquivista e de Técnico de Arquivo, e dá outras providências. Brasília, 1978 Disponível em: <http://www.planalto.gov.br/ccivil 03/leis/1970-1979/L6546.htm>. Acesso em: 15 ago. 2014. 
BRASIL. Lei no 8.159, de 8 de janeiro de 1991. Dispõe sobre a política nacional de arquivos públicos e privados e dá outras providências. Brasília, 1991. Disponível em: <http://www.planalto.gov.br/ccivil_03/leis/L8159.htm>. Acesso em: 15 ago. 2014.

BRASIL. Lei $n$ ㅇ 12.527, de 18 de novembro de 2011. Regula o acesso a informações previsto no inciso XXXIII do art. 5o, no inciso II do § 30 do art. 37 e no $\S 20$ do art. 216 da Constituição Federal; altera a Lei no 8.112, de 11 de dezembro de 1990; revoga a Lei no 11.111, de 5 de maio de 2005, e dispositivos da Lei no 8.159, de 8 de janeiro de 1991; e dá outras providências. Disponível em: <http://www.planalto.gov.br/ccivil_03/_ato20112014/2011/lei/l12527.htm>. Acesso em: 15 ago. 2014.

CATANI, Afrânio Mendes; OLIVEIRA, João Ferreira de; DOURADO, Luiz Fernandes. Política educacional, mudanças no mundo do trabalho e reforma curricular dos cursos de graduação no Brasil. Educação \& Sociedade, ano XXII, n. 75, ago. 2001. p.16 p.17 p.18

CESARINO, M. A. da N.; VIANNA, M. M. O Curso de Graduação em Biblioteconomia da UFMG. Revista da Escola de Biblioteconomia da UFMG, Belo Horizonte, v. 19, n. especial, p. 37-67, 1990. P.51

CHESNAIS, François. A mundialização do capital. Trad. Silvana FinziFoá. São Paulo: Xamã, 1996.

CHOO, Wei Chun; DETLOR, Brian; TURNBULL, Don. "A behavioral model of information seeking on the Web - Preliminary results of a study of how managers and IT specialists use the Web. Proceedings of the ASIS Anual Meeting, n. 35, p. 290-302, 1998.

COSTA, Marli Guedes da. Acesso aos arquivos públicos: aspectos jurídicos e práticos. Cenário Arquivístico, Brasília, DF, v. 4, n. 1, p. 22-31, jan./ jun., 2011.

COUTURE, Carol; MARTINEAU, Jocelyne; DUCHARME, Caniel. A formação e a pesquisa em arquivística no mundo contemporâneo. Brasília: FINATEC, 1999.

COUTURE, Carol. Les fonctions de l'archivistique contemporaine. Canadá: Presses de l' Universitédu Quebéc, 2003.

CUNHA, M. B. Metodologia para estudo dos usuários da informação científica e tecnológica. Revista de Biblioteconomia de Brasília, Brasília, v. 10, n. 2, p. 5-19, 1981.

CURY, Carlos R.J. Reforma universitária na nova Lei de Diretrizes e Bases da Educação Nacional? Cadernos de Pesquisa, São Paulo: Fundação Carlos Chagas, no 101, p. 3-19, jul. 1997.

DECLARAÇÃO UNIVERSAL DOS DIREITOS DO HOMEM. Paris, 1948. Disponível em: $<$ http//www.direitoshumanos.usp.br>. Acesso em: 15 ago. 2014

DERVIN, B. An overview of sense-making research: Concepts, methods and results to date. Paper presented at the International Communication Association Annual Meeting, Dallas, TX. May, 1983.

DERVIN, B.; NILAN, M. Information needs and uses. Annual Review of Information Science and Technology, v. 21, p.3-33, 1986.

DOOLEY, J. Subject indexing in context. American Archivist, Chicago, v. 55, p. 344-354, 1992 apud ARAÚJO, Carlos Alberto Ávila. A perspectiva de estudos sobre os sujeitos na Arquivologia, na Biblioteconomia e na Museologia. Revista da Faculdade de 
Biblioteconomia e documentaçãoda UFGRS. Porto Alegre, v. 19, n. 1, p. 213-238, jan./jun. 2013.

DOURADO, Luiz F.; CATANI, Afrânio M. (Orgs.). Universidade pública: Políticas e identidade institucional. Campinas/Goiânia: Autores Associados/Editora da UFG, 1999.

DOURADO, Luiz F.; OLIVEIRA, João F. Políticas educacionais e reconfiguração da educação superior no Brasil. In: DOURADO, Luiz F.; CATANI, Afrânio M. (Orgs.), Universidade pública: Políticas e identidade institucional. Campinas/Goiânia: Autores Associados/Editora da UFG, 1999, p. 5-22

DOWLE, Lawrence. Agenda de investigación sobre La disponibilidad y uso de losarchivos. Foro Archivistico, Mexico, n.4. jul./dec. 1992.

DUCHEIN, Michel. Obstacles to the access, use and transfer of information from archives: a RAMP study. Paris: Unesco - General Information Programm; Unisist, 1983.

DUCHEIN, Michel. "La profesión de archivero entre elpasado y el future". Revista Catalana d'Arxivística, Lligall. n.4, p. 13-24, 1991.

DUCHEIN, Michel. Archives, archivistes, archivistique: definitions et problématique. In: DIRECTION DES ARCHIVES DE FRANCE. La pratique archivistique française. Paris: Archives Nationales, 1993. p. 19-39.

DUDZIAK, Elizabeth Adriana. Competência Informacional: análise evolucionária das tendências da pesquisa e produtividade científica em âmbito mundial. Informação \& Informação, Londrina, v.15, n.2, p.1-22, jul./dez. 2010.

ELLIS, David. A Behavioral Model for Information Retrieval System Design. Journal of Information Science, Cambridge, n. 15, p. 237-247, 1989.

FIGUEIREDO, Nice Menezes de. Estudos de usos e usuários da informação. Brasília: IBICT, 1994.

GAGNON-ARGUIN, Louise. Les courants de penséesurl'archivistiqueau Québec. In: L'archivistique: son historie, sés acteuursdepuis 1960. Saint-Foy: Presses de l'Universitédu Québec, 1992.

GONZÁLEZ TERUEL, Aurora. Los Estudios de necesidades y usos de la información: fundamentos y perspectivas actuales. Gijón: Treas, 2005.

HARVEY, David. Condição pós-moderna. Trad. de Adail Ubirajara Sobral e Maria Stela Gonçalves. São Paulo: Edições Loyola, 1992.

HONORIO, Cristiane da Cruz; DAMASCENO, Elizabeth Abreu. O direito á informação e os métodos de divulgação de arquivos e seus acervos. In: CONGRESSO NACIONAL DE ARQUIVOLOGIA, II, 2006, Porto Alegre. Anais... Porto Alegre, RS, 2006 apudCOSTA, Marli Guedes da. Acesso aos arquivos públicos: aspectos jurídicos e práticos. Cenário Arquivístico, Brasília, DF, v. 4, n. 1, p. 22-31, jan./ jun., 2011.

ICA.ORG - Conselho Internacional de Arquivos. Disponível em: <http://www.ica.org/>. Acesso em: 15 ago. 2014a. 
ICA.ORG - Congresso Internacional de Arquivos. Disponível em: <http://www.ica.org/12593/about-annual-conference/annual-conferences.html>. Acesso em: 15 ago. 2014b.

JARDIM, José Maria. O acesso à informação arquivística no Brasil: problemas de acessibilidade e disseminação. Caderno de Textos. Mesa Redonda Nacional de Arquivos, 1999. Rio de Janeiro: Arquivo Nacional, 1999.

JARDIM, José Maria; FONSECA, Maria Odila (org.). A formação do arquivista no Brasil. Rio de Janeiro: EdUFF, 1999.

JARDIM, José Maria; FONSECA, Maria Odila. Estudos de usuários em arquivos: em busca de um estado da arte. Revista de Ciência da Informação, Rio de Janeiro, v. 5, n. 5, out. 2004. Disponível em: <http://www.dgz.org.br/out04/Art_04.htm>. Acesso em: 20 ago. 2014.

JIMERSON, R. Redefining archival identity: meeting user needs in the information society. American Archivist, Chicago, v. 52, p. 332-340, 1989 apud ARAÚJO, Carlos Alberto Ávila. A perspectiva de estudos sobre os sujeitos na Arquivologia, na Biblioteconomia e na Museologia. Revista da Faculdade de Biblioteconomia e documentaçãoda UFGRS. Porto Alegre, v. 19, n. 1, p. 213-238, jan./jun. 2013.

KURTZ, Clara Marli Scherer. O usuário do Arquivo Nacional e o seu relacionamento com os serviços oferecidos para a satisfação de suas necessidades de informação. Dissertação (Mestrado em Ciência da Informação) - Instituto Brasileiro de Informação em Ciência e Tecnologia/Universidade Federal do Rio de Janeiro 1990.

KUHLTHAU, Carol C. Inside de Search Process: information seeking from the user's perspective. Journal of the American Society for Information Science, Washington, DC, v. 42 , n. 5 , p. $361-371,1991$

LANCASTER, F Wilfrid. Information retriewal systems: characteristics, testing and evaluation. 2. ed. New York: Willy-Interscience, 1979.

LE COADIC, Yves F. Usage et usagers de l'information. Paris: Nathan, 1997.

LIPETZ, B.Information needs and uses. Annual Review of Information Science and Technology, v. 6, p. 3-32, 1970 apud GONZÁLEZ TERUEL, Aurora. Los Estudios de necesidades y usos de la información: fundamentos y perspectivas actuales. Gijón: Treas, 2005.

MARQUES, Angélica Alves da Cunha; RONCAGLIO, Cynthia; RODRIGUES, GeorgeteMedleg (org.). A formação e a pesquisa nas universidades públicas brasileiras: I Reunião Brasileira de Ensino e Pesquisa em Arquivologia. Brasília: Thesaurus, 2011.

MARTÍN-POZUELO, M. Paz. Los entornos y documentos electronicos? Efecto Edison para laformación archivística. Ponto de acesso. Salvador, BA, v. 3, n. 1, p. 6-33, abr. 2009. p.31

MATA CASTILIÓN, José Manuel. La situación professional de losarchiveros latinoamericanos. Boletim Anabad, Madrid, v. 31, n. 2, p.235-248, 1981 apud SOUZA, Kátia Isabelli Melo de. Arquivista: visibilidade profissional:formação, associativismo e mercado de trabalho.Brasília:Starprint, 2011. 
MENNE-HARITZ, Angelika. Formation em arquivistique: pourrépondreauxbesoins de lasociéte Du XXI e siécle. In: CONGRÉS INTERNACIONAL DES ARCHIVISTE, 12, 1992, Montreal, Texte de conférence... Montreal: [s.n.], 1992.

MOURA, Maria Aparecida (Org.). A construção social do acesso Público à Informação no Brasil: contexto, historicidade e repercussões. Belo Horizonte: Editora UFMG, 2014.

NEGREIROS, Leandro; ARREGUY, Cintia; SILVA, Welder. Metodologia para análise, avaliação e reestruturação curricular de cursos de arquivologia: a experiência do curso do curso de arquivologia da Escola de Ciência da Informação da Universidade Federal de Minas Gerais. Anais... V Congresso Nacional de Arquivologia. Salvador, 2012.

PAES, Marilena Leite. Arquivo: teoria e prática.7ª: reimp. Rio de Janeiro: Editora FGV, 2007.

PAIVA, Marília de Abreu Martins de. Os arquivos e o acesso à informação pública no Brasil: desafios e perspectivas. In: MOURA, Maria Aparecida (Org.). A construção social do acesso Público à Informação no Brasil: contexto, historicidade e repercussões. Belo Horizonte: Editora UFMG, 2014

PUGH, M. J. The Illusion of omniscience: subject access and the reference archivist. American Archivist, Chicago, v. 45, p. 33-44, 1982 apud ARAÚJO, Carlos Alberto Ávila. A perspectiva de estudos sobre os sujeitos na Arquivologia, na Biblioteconomia e na Museologia. Revista da Faculdade de Biblioteconomia e documentaçãoda UFGRS. Porto Alegre, v. 19, n. 1, p. 213-238, jan./jun. 2013.

RENÉ-BAZIN, Paule. Qui assurera La formation et comment? Avons-nous besoind'uminstitueuropeen: Janus, v.2, p. 227-229, 1992.

RIFKEN, Jeremy. O fim dos empregos: o declínio inevitável dos níveis de emprego e a redução da força global de trabalho. Trad. de Ruth Gabriela Bahr, São Paulo, Makron, 1995.

ROUSSEAU, Jean-Yves; COUTURE, Carol. Os fundamentos da disciplina arquivística. Lisboa: Publicações Dom Quixote, 1994.

ROSSEAU, Jean-Yves; COUTURE, Carol. Os fundamentos da disciplina arquivística. Lisboa: Dom Quixote, 1998

SCHELLENBERG, Theodore Roosevelt. Arquivos modernos: princípios e técnicas. $2^{\mathrm{a}}$ ed. Rio de Janeiro: Ed. Fundação Getúlio Vargas, 1973 apud JARDIM, José Maria; FONSECA, Maria Odila. Estudos de usuários em arquivos: em busca de um estado da arte. Revista de Ciência da Informação, Rio de Janeiro, v. 5, n. 5, out. 2004. Disponível em: <http://www.dgz.org.br/out04/Art_04.htm>. Acesso em: 20 ago. 2014.

SILVA, A. M. et al. Arquivística: teoria e prática de uma ciência da informação. Porto: Afrontamento, 1999.

SILVA, Armando Malheiro da; RIBEIRO, Fernanda. "Formação, perfil e competências do profissional da informação". In: CONGRESSO NACIONAL DE BIBLIOTECÁRIOS, ARQUIVISTAS E DOCUMENTALISTAS. ( $8^{\circ}$ estoril, 2004). Nas encruzilhadas da informação e da cultura: (re) inventar a profissão; actas, Associação Portuguesa de Bibliotecários, Arquivistas e Documentalistas, Estoril, Lisboa. Cd-rom (2004). Disponível em: < http://www.apbad.pt.>. Acesso em: 20 ago. 2014. 
SILVA, Denise de Almeida. Arquivos: uma abordagem sobre o termo usuário. Cenário Arquivístico, Brasília-DF, v. 4, n. 1, p. 9-21, jan./jun., 2011.

SILVA, Tomas Tadeu da. Documentos e de identidade: uma introdução às teorias do currículo. $2^{a}$ ed. Belo Horizonte: Autêntica, 2007.

SOUZA, Kátia Isabelli Melo de. Arquivista: visibilidade profissional: formação, associativismo e mercado de trabalho. Brasília: Starprint, 2011.

TÁLAMO, Maria de Fátima. Informação: organização e comunicação. IN: SEMINÁRIO DE ESTUDOS DE INFORMAÇÃO, 1, 1996. Anais... Niterói: Eduff, 1996.

TAYLOR. Hugh A. Los servicios archive y el concepto de usuário: studiodel RAMP. Paris: Unesco, 1984 apud COSTA, Marli Guedes da. Acesso aos arquivos públicos: aspectos jurídicos e práticos. Cenário Arquivístico, Brasília, DF, v. 4, n. 1, p. 22-31, jan./ jun., 2011.

WILSON,T.D. On user studies and Information needs. Journal of Documentation, 37 (1): 3-15, March 1981.

WILSON, Ian. Strategies for communication. Journal of the Society of Archivistis, Paris, v.16, n. 1, p. 55-69, 1995.

\section{Apêndice 1}

\section{Entrevista:}

1. Que tipo de saberes deve ter o arquivista?

2. A formação oferecida nas universidades consegue atender as demandas atuais?

3. Quanto ao acesso aos arquivos, quais são em sua opinião, as barreiras encontradas atualmente?

4. Que papel poderia ter "os estudos de usuários" na arquivologia?

5. Como você definiria a bibliografia utilizada?

6. A bibliografia utilizada é específica da arquivologia ou de áreas correlatas?

7. Sobre a lei de acesso a informação de 2011, você acredita que ela traz algum impacto para a área?

8. Com os avanço das tecnologias de informação e comunicação, surge um novo tipo de usuário, o usuário remoto, que mudanças isso traz para o campo?

9. Na sua opinião, a que se deve o estado incipiente dos estudos de usuários na arquivologia?

10. Existem diferenças do uso e de usuários em cada uma das três idades dos arquivos?

11. Se sim, explique sobre o uso da informação e sobre os usuários em cada uma delas:

12. Sobre a harmonização dos currículos de arquivologia, qual a sua opinião a respeito?

13. Você acredita que a sociedade demonstra interesse nos documentos de arquivos?

14. Diversos autores afirmam que a falta de interesse por parte da sociedade, se deve ao desconhecimento dos serviços de arquivos. Quais medidas podem ser tomadas para que o usuário potencial possa ser atingido? 
15. Atualmente vários arquivos públicos tem trabalhado com montagem de exposições nos seus espaços. Essa medida pode ser considerada como um fator importante para favorecer a mediação arquivística?

16. O que é arquivologia?

17. Defina o que é arquivista: 